Győriné Szabó Gabriella

\title{
A KOHÉZIÓS ALAPOK MINŐSÉGI \\ FELHASZNÁLÁSÁNAK FELTÉTELEI \\ ÉS KIHÍVÁSAI
}


Társadalomtudományi és Nemzetközi Kapcsolatok Kar

Világgazdasági Intézet

Témavezető: Kengyel Ákos Dr. habil, Ph.D.

Bíráló Bizottság névsora: 


\section{Budapesti Corvinus Egyetem}

NEMZETKÖZI KAPCSOLATOK MULTIDISZCIPLINÁRIS

DOKTORI ISKOLA

A kohéziós alapok minőségi felhasználásának

feltételei és kihívásai

doktori értekezés

Győriné Szabó Gabriella

Budapest, 2016. 



\section{Tartalomjegyzék}

Táblázatok, ábrák, illusztrációk jegyzéke....................................8

Mottó........................................................................... 10

BEVEZETÉS ........................................................ 11

I.RÉSZ: FOGALMI HÁTTÉR, SZAKIRODALMI KÖRNYEZET, MÉRÉSI

GYAKORLATOK ÉS EREDMÉNYEK..................................... 17

1. FEJEZET: HATÉKONYSÁG, PARTNERSÉG, SZUBSZIDIARITÁS .....17

1.1 Fókuszált fogalomvizsgálat................................17

1.2 Szubszidiaritás és partnerség - nem csak elvek szintjén.............19

$1.3 \quad$ Alapfogalmak összegzése.....................................23

2. FEJEZET: TAGÁLLAMI ÉS UNIÓS SZINTÜ HATÉKONYSÁGI MÉRÉSEK SZINTÉZISE....................................23

2.1 Tagállamok értékelési tapasztalatai.............................23

2.2 Uniós szintü mérési gyakorlatok, elvárások......................33

2.3 Értékelések összefoglaló szintézise és a hazai tíz éves gyakorlat összehasonlító bemutatása.....................................33

3. FEJEZET: AZ INTÉZMÉNYRENDSZER SZEREPE A TÁMOGATÁSOK

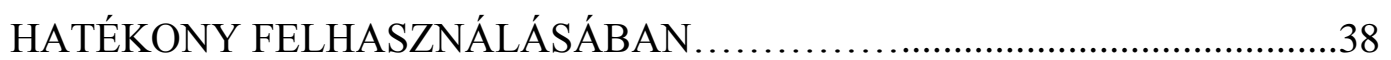

3.1 Az intézményrendszer és a hatékonyság szakirodalmi

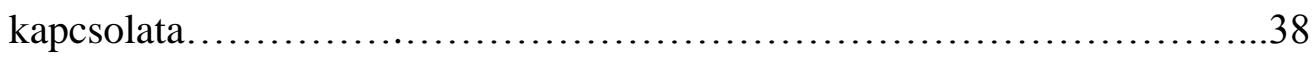

3.2 A 2014-2020-as uniós jogszabályalkotás a minőségi költés jegyében -

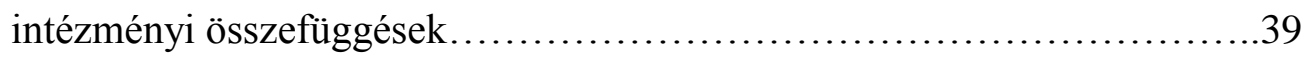

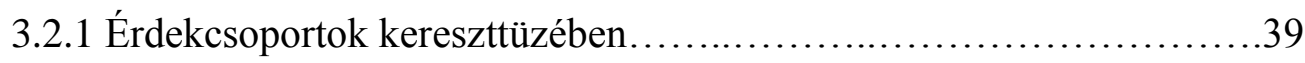

3.2.2 A 2014-2020 közötti költségvetést szabályozó hatályos rendeletek hatékonyság korlátozó hozadéka - Szándékok és eredmények.....42 


\section{FEJEZET: MAGYAR INTÉZMÉNYRENDSZERI SAJÁTOSSÁGOK,}

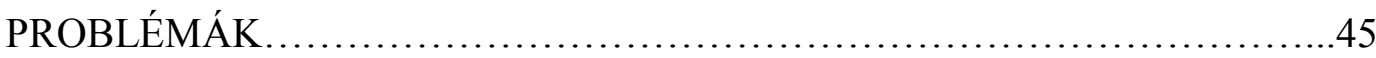

4.1 Hazai intézményi változások - hátraarc egy évtized alatt...............45

4.2 Intézményrendszeri összetettség.................................48

4.3 Az Európai Bizottság új programozási elvárásai a tagállami programalkotás folyamatában - magyar vonatkozások az eredeti minőségi szándék torzulásának tükrében....................................51

4.4 Az új hét éves forráskeret hazai felhasználásának programterve egy megyei területfejlesztési program tükrében

4.4.1 A hazai operatív programok és az új területfejlesztési alapegység egymásra épülésének kérdései .55

4.4.2 Magyarország operatív programjainak bemutatása egy megyei területfejlesztési stratégia tükrében .58

4.5 Összegzés. .66

II.RÉSZ: ESETTANULMÁNY ÉS ESETLEÍRÁSOK A HAZAI TÁMOGATÁSFELHASZNÁLÁS ÉVTIZEDÉBÖL.......................................67

1. FEJEZET: ILLUSZTRATÍV ESETTANULMÁNY - A PROGRAMSZINTÜ HATÉKONYSÁG JÓ GYAKORLATA......................................68

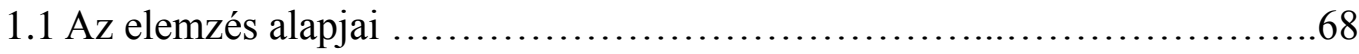

1.2 Programszintü példa a hazai intézményrendszerben........................70

1.3 A Teszler-féle elmélet és hazai intézményi gyakorlat szintézise tagságunk első tíz évében.

1.4 Széchenyi 2020 Ügyfélszolgálat - Fejlesztett megoldás az új programozási időszakra .80

1.5 Konklúzió, javaslatok .82 
2.1 Tartartalék-felhasználás szabályozásának változása a racionalitás jegyében..83

2.2 ÁFA, mint állami direktfinanszírozás: a nettó befizetők jogos kritikája.......84

2.3 Nyílt pályázati eljárásrend a három programozási periódusban..............86

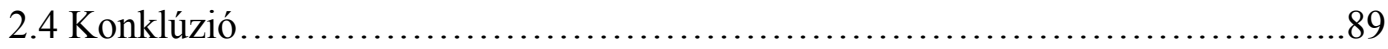

III.RÉSZ: KONTRAFAKTUÁLIS MIKROÖKONÓMIAI ÖSSZEHASONLÍTÓ VIZSGÁLAT PROGRAM-, ÉS PROJEKTSZINTEN...........................90

1.FEJEZET: KUTATÁSI KERETEK, FELTÉTELEK MEGHATÁROZÁSA ..90

1.1 Kutatási probléma megfogalmazása ............................................90

1.2 Nemzetközi módszertani alapok áttekintése és a hazai adaptáció

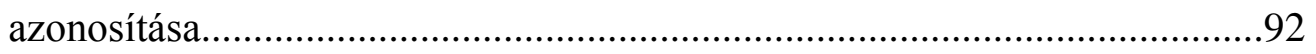

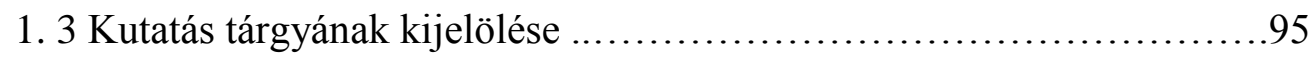

2. FEJEZET: AZ EMPIRIKUS MUNKA MEGVALÓSÍTÁSA ..................98

2.1 A terv-tény projektpárok vizsgálata............................98

2.2 Vizsgálati scope kiterjesztése a komplexitás érdekében................103

2.3 A tényellentétes vizsgálat következtetései a hatékonyság definíciós kritériumai alapján és a hipotézisek bizonyítása.......................111

KÖVETKEZTETÉSEK................................................ 115

HIVATKOZÁSOK JEGYZÉKE........................................... 122

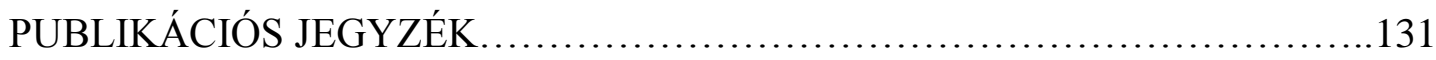

FÜGGELÉK: A kontrafaktuális összehasonlító vizsgálat eljárásrendi, számítási háttéranyaga és teljes projekt-adatbázisa településenként digitális adathordozón 


\section{Ábrák, táblázatok, illusztrációk jegyzéke}

\section{Ábrák jegyzéke}

1. ábra: A brit Nemzeti Audit Hatóság stratégiája. .26

2. ábra: Magyarország támogatás-felhasználási intézményrendszere a 20072013-as programozási periódusban.

3. ábra: A támogatás-felhasználás kapcsolati hálója Magyarországon a 20072013-as fejlesztési időszakban.

4. ábra: EU 2020 CÉLKITÜZÉSEK

5. ábra: Magyarország vállalásai a Partnerségi Megállapodás szerint.

6. ábra:. Magyarország egyes operatív programjainak forrásarányos megoszlása

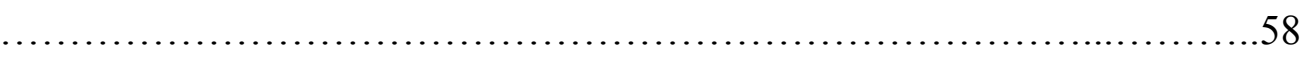

7. ábra: Élelmiszeripari támogatások lehatárolási szabály-rendszere.

8. A 2007-2013-as programozási periódus projekt kiválasztási eljárásrendje.

\section{Táblázatok jegyzéke}

1. táblázat: Mérési és értékelési gyakorlatok tagállami összehasonlítása .54

2. táblázat: A magyarországi forrásallokációs programalkotási arányok a 20142020-as programozási periódusban.

3. táblázat: A Jászberényi és Kisvárdai kistérség település-és projektszámai...99

4. táblázat: A két térség terv/tényadatai a humán infrastruktúra fejlesztése forráskeretben

5. táblázat: Abszorpció szerinti település megoszlások

6. táblázat: A két térség egészségügyi alapellátásra vonatkozó fejlesztéseinek alakulása. 
7. táblázat: Jászboldogháza egészségház felújításának pályázati története.....109

\section{Illusztrációk jegyzéke}

1. kép: Multifunkciós csarnok „használat közben” a jászfényszarui ipari parkban............................................................ 84

2. kép: Jászboldogháza felújított egészségháza 2014-ben.....................109 
Mottó: A brit Nemzeti Audit Hatóság jelmondata:

„Küldetésünk: segíteni a nemzetet bölcsen költeni. (NAO [2009])” 


\section{BEVEZETÉS}

Az Európai Unió regionális fejlesztési politikájának kiemelt fogalmai az abszorpció, a felhasználás hatékonysága, hatásossága és eredményessége. Ezek a mutatók minősítik a szakpolitika müködését uniós és tagállami szinten egyaránt. A megvalósítás zárásához érkezett 2007-2013-as programozási időszak értékelésénél és az új, 2014-2020 tervezési periódus jogszabályi kialakításánál is előtérbe kerültek a források felhasználásának mennyiségi és minőségi mutatói. A gazdasági válság hatására hangsúlyeltolódást látunk az új szinonimaként minőségi költésnek is nevezett hatékonyság irányába. Ezt az a tény is erősíti, hogy az Európai unió életében és annak kohéziós politikája során először történt meg a kohéziós források amúgy sem jelentősnek mondható finanszírozási keretcsökkenése. Reálértéken 8\%-kal kevesebb forrás áll rendelkezésre összevont tagállami szinten az új programozási periódusban a zárásához érkezett 2007-2013-as időszakhoz képest. Kutatásom célja, hogy a kohéziós támogatások hatékony felhasználását segítsem elő javaslatokkal a hazai és bizottsági intézményrendszeri szabályozás szintjein, valamint a hatékonyságot eredményező beavatkozási lépéseket azonosítsam a tagállami tervezési és megvalósítási szakaszokban egyaránt. Kutatásom épít Kengyel Ákos habilitációs értekezésében bizonyított harmadik hipotézisre, mely szerint az EU kohéziós politikájának szabályozási kereteit elemezve megállapította, hogy a támogatási rendszer nem egy jóléti transzfermechanizmus, hanem nagyon szigorú feltételrendszer alapján müködő fejlesztéspolitika. Disszertációm abban egészíti ki munkásságát, hogy a hazai fejlesztéspolitikai dokumentumokon keresztül láttatja a szintén itt jelzett problémát, hogy az Európa 2020 stratégia tematikus célkitüzéseihez való kapcsolódás túl sok tevékenység támogatását teszi lehetővé (írja elő), ezáltal a kívánatos koncentráció helyett éppen ellentétes irányú folyamat következik be (Kengyel [2015b]).

A nemzetközi és magyar szakirodalmi és kutatási környezet széleskörü vizsgálata további két eredményt is hozott a teoretikai kérdések mellett. Különösen a brit példára tekintettel azt láthatjuk, hogy egy különálló intézmény felel - és a Parlament Alsóházának jelent - a támogatások felhasználásáról, annak koordinált ellenőrzésével 
és az uniós elöírásokon túli belső igény vezérelte iránymutatással. Második pozitív externáliaként azonosítottam azokat a további tagállami vizsgálati gyakorlatokat, melyekkel a transzferek felhasználását értékelik. Mindkét eredmény hazai adaptációja vizsgálandó és az értekezés átfogó céljához járul hozzá. A széleskörű tagállami áttekintés alapján megállapítható, hogy a hatékonyság fogalma nem egységes, nem definiált uniós és tagállami szinteken sem, együttesen kezelik olykor összekeverik - a hatásossággal, eredményességgel, és olykor még az abszorpcióval is történnek átfedések. Ez utóbbi annyiban igaz és vizsgálandó, hogy az abszorpciós elmaradások következtében a támogatások hatékonysága nulla. Disszertációm abban lép túl az eddigi megállapításokon, hogy a teoretikai kérdésre egy összehasonlítással adok választ közel valamennyi tagállamot megjelenítve, hogy mely tagországokban mit értenek hatékony felhasználás alatt, hogyan mérik azt, milyen értékelő vizsgálatokat végeztek, és abban milyen szerepet kap a fogalom vizsgálata, mérése.

A kutatásom fókusza - jóllehet az eddig fellelhető szakirodalom nem mutat ilyen irányú szükítést - lehetőség szerint korlátozódik a hatékonyság mérésére, két okból:

- A szakirodalom és a téma mérete meghaladja, hogy együtt kezeljem a többi fogalommal, ez általánosításokhoz vezethet, és felületes vizsgálatokat eredményezne.

- A hatásvizsgálatok és eredményesség szempontú megközelítés szakirodalma igen széles, több fórumon és platformon megjelenik, jóllehet a hatékonysági probléma mérete nem törpül el ezek mellett. Indokolatlanul kisebb figyelem hárul utóbbi metodikájának és megoldásainak vizsgálatára, jóllehet a hiányosságával keletkező probléma elérheti, meghaladhatja a hatásossági és eredményességi elmaradásokat.

Szintén a nemzetközi és hazai kutatási előzmények alapján axiómaként kijelenthető, hogy a felzárkóztatási források felhasználását szabályozó, irányító, megvalósító intézményrendszer kialakításának és müködése módja befolyásolja a felhasználás hatékonyságát. Számos kutatási munkában két, az Európai Uniót összességében is meghatározó alapelv - a szubszidiaritás és a partnerség - érvényre jutásától teszik függővé a minőségi müködést. 
Hipotéziseimben azt állítom, valamint munkám során annak bizonyítása történik, hogy a szubszidiaritással és partnerséggel meghatározott fejlesztések hatékonyabbak az ezt nélkülöző megoldásoktól, kimenetektől. A két alapelv érvényre jutását meghatározza az intézményrendszer és annak előzményeként létrehozott jogszabályi környezet mind uniós, mind tagállami szinten egyaránt, így első hipotézisem az alábbi:

\section{H1: Az intézményrendszer kialakítását és müködését meghatározó jogszabályi rendszer determinálhat hatékonysági problémákat.}

Ennek bizonyítására vizsgálom a 2014-2020-as programozási időszak Európai Strukturális és Beruházási alapok (továbbiakban ESB alapok) felhasználási jogszabályi keretrendszerét a hatékonyság tükrében, valamint azt az ehhez vezető 25 hónapos egyeztetési folyamatot, mely a tagállami és bizottsági szempontokat megjelenítette szintén a minőségi költés fókuszában (II. RÉSZ).

A hatékonyság fogalmi hiányának pótlása érdekében végzett szintetizáló munkám során, az egyes tagállamok értékelési gyakorlatát vizsgálva azt láthatjuk, hogy monitorozási tevékenységük megjelenik mind az intézményi működés, mind a program-és projektalkotás/kiválasztás szintjén is. A projektszintủ vizsgálatok szinte kizárólag eredményességi kérdésekre terjednek ki, és aggregált hatásmechanizmusokra. Megítélésem szerint azonban projektszinten is valós igény a hatékonyság vizsgálata, ahol vizsgálni szükséges, hogy:

- egy adott fejlesztés - függetlenül annak infrastrukturális vagy „szoft” tartalmától - megvalósítása miért szenvedett késedelmet (a programozási időszak végéhez közel eső megvalósítás időbeni elhúzódása abszorpciós veszélyeket hordoz, a megvalósítás során keletkező egyenetlen munkahullámok pedig intézményi kapacitásproblémákat);

- a tervezett költségvetéshez képest hogyan alakult a tényleges megvalósítás során jelentkező forrásigény;

- milyen járulékos költségek terhelték a fejlesztést (ezek létének és mértékének vizsgálata az intézményrendszer müködési problémáira, és jogszabályi előfeltételek túlzó vagy nem megfelelő kialakítására reflektál(hat)); 
- a tervezett tartalmon túl milyen többlet-tevékenységek valósultak meg kötelező vagy opcionális jelleggel.

A programszintü értékelésekben megjelennek hatékonysági szempontok, ezek között az előre-jelezhetőséget, rugalmasságot, jövő-orientált tervezést, folyamat-közbeni monitorozást és értékelést, valamint területi szinergiát várva el az intézményrendszertől. Értekezésemben ezért az intézményrendszer-szintủ aspektust különösen szükségesnek tartom megjeleníteni.

A fentiek alapján további hipotéziseimet így határoztam meg:

H2a: Az intézményrendszer müködésében, müködési struktúrájában érvényesített adekvát szubszidiaritás és legitim partnerség javítja a hatékony felhasználást.

H2b: A programtervezés, projektgenerálás, projektkiválasztás során megjelenő adekvát szubszidiaritás és legitim partnerség javítja a hatékony felhasználást.

H2c: A projektmegvalósítás során alkalmazott adekvát szubszidiaritás és legitim partnerség javítja a hatékony felhasználást.

Míg a H2a és H2b hipotézis esetében intézményi megközelítés dominál, addig a H2c állítást a felhasználói, vagyis pályázói és kedvezményezett/támogatott szemszögéből értékelem elsősorban. Az értékelés időhorizontja a 2004-es uniós tagságunk teljes spektruma, mely lehetőséget ad az idő közben történt olyan változások bemutatására, amelyek témánk szempontjából releváns és egy hiánypótló átfogó összegzést ad a magyarországi felhasználás hatékonyság-szempontú áttekintéséből.

A kutatásom módszerei:

- Dokumentumelemzésem kiterjed a hazai és nemzetközi kutatóintézetek tanulmányaira, joganyagokra, hatásvizsgálatokra, az Európai Bizottság Regionális Főigazgatóságához intézett adatkéréseim elemzésére, útmutatók kiértékelésére (kiemelten az Európai Bizottság Evaluation Guideline-t). A dokumentumelemzés mindkét hipotézis bizonyításához hozzájárul, továbbá uniós és hazai intézményi szabályozásba adaptálható 
tagállami jó gyakorlatokat emelek ki, javaslatokat fogalmazok meg (I.RÉSZ).

- A programszintü esettanulmányom a 2004. óta Magyarországon megvalósított, az Európai Unióban jó gyakorlatnak minősített - jelenleg Széchenyi 2020 Ügyfélszolgálat elnevezést viselő - intézményi példája a második hipotézis valamennyi alpontjára reflektál (II. RÉSZ).

- A projektszintü esetleírások a hazai megvalósítás több mint egy évtizedes, három programozási időszak gyakorlatából származnak, melyekből általános, intézményi szinten adaptálható javaslatokat fogalmazok meg azon túl, hogy a második hipotézis bizonyítására használom. Itt válik láthatóvá a minőséget fémjelző fogalmak összetettsége és mérhetőségének nehézségei a megvalósítás szakaszában (II. RÉSZ).

- Kutatási munkám kiemelt sarokpontja egy német és cseh tagállami mérési gyakorlat első magyarországi adaptációja, mely során program és projektszinten valósítok meg mikroökonómiai kontrafaktuális (tényellentétes) összehasonlító vizsgálatot, mellyel szintén mindkét hipotézis valamennyi alpontjának bizonyításához járulok hozzá. A kutatásom erőssége, hogy a szakirodalom definíciója alapján természetesnek nevezhető, vagyis valós környezetben zajlott a 2007-ben tett, "előzetes" projektszelekció, és valós környezetben zajlik a 2015-ös utólagos adatvizsgálat is; a tényleges intézményrendszeri szabályozási és müködési környezetben, a valós térségi szereplőkkel, legitim döntési mechanizmus mentén. A vizsgálat különlegessége, hogy nem klasszikus terv-tény összehasonlítás történik, jóllehet a tárgya azonos a két vizsgált időpontban (III. RÉSZ).

Kutatásom során nem vizsgálom a Vidékfejlesztési Alap forrásainak felhasználását, jóllehet a 2014-2020-as időszakban a Közös Stratégiai Keretbe ismét integrálják -, és a közösségi kezdeményezéseket, mert szakirodalmi, metodikai hátterük jelentősen eltér a kohéziós forrásoktól. Továbbá ezek gyakorlati hátterére sincs rálátásom, míg a három alap felhasználását tekintve kettő intézményi szintü munkatapasztalatom (Regionális Programok Irányító Hatóságánál és Észak-Alföldi Regionális Fejlesztési Ügynökségnél végzett munkám), és három fajta felhasználói (KKV, civil szervezet, 
oktatási intézmény) projektmenedzsment tapasztalattal rendelkezem. Nem képezik vizsgálatom tárgyát a visszaélésekre, korrupcióra, járadékvadászatra példát és gyanút adó esetek sem, melyeket nem az elhanyagolható mértékük okán mellőzök, hanem terjedelmi okokból, és egyéb végrehajtási intézményi szereplők bevonásának feltétele hiányában.

Hipotéziseim bizonyítását a fenti módszertanok ötvözetének alkalmazásával teszem, melyekből az alábbi főbb következtetés vonhatóak le:

Mind a megfelelő partnerség, mind a szükséges és elégséges mértékü szubszidiaritás elengedhetetlen a forrásfelhasználás hatékony megvalósításához, valamint az intézményrendszer kialakításának és müködésének szabályozásából származhatnak hatékonysági problémák. A disszertációban megfogalmazott új intézményi javaslatok, és adaptálásra javasolt mérési módszerek (ezek összetett alkalmazására kerül sor a kontrafaktuális összehasonlító elemzésem során) mind bizottsági szinten, mind tagállami - elsősorban hazai - szinten megjelennek. Legfontosabb megállapítása, hogy a két vizsgált alapelv kiterjedtebb és tudatosabb - vagyis adekvát mértékü szubszidiaritás és legitim partnerség - szükséges a teljes programozás folyamán, ezzel szükségesen együtt járó hangsúlyeltolódások a feladat-, felelősség- és hatáskörökben mind unió-tagállam és tagállam-szubnacionális szintek között. A javaslatok tételes számbavételét követően látható, hogy ezek érvényesítésének humán-erőforrás igénye számottevő, ugyanakkor megítélésem szerint nem jelentene többlet humán-eröforrás igényt az intézményrendszerben, hanem hangsúlyeltolódásokat, átstrukturálásokat és másként gondolkodást tenne szükségessé. Különösen igaz ez a digitalizálás, e-pályázással együtt járó kapacitásfelszabadulás okán. Ugyanakkor az a kritika sem mellőzhető, hogy az intézményi szabályozási elvárások mennyire rugalmatlanul determinálják programozási szinten egy tagország forrás-felhasználását, és mennyi „felesleges mozgásteret” engednek a megvalósítás mikéntjében a kedvezményezettek irányába projekt és intézményi szinten egyaránt. Mindkét jelenséget károsnak tartom kutatási eredményeim alapján. Vizsgálatom szerint a Bizottság és a kutatóintézetek eredményei alapján készülhetnének egzakt megoldásokat tartalmazó megvalósítási szabályozások annak érdekében, hogy ne a közbenső és utólagos auditok eredményezzenek kötelezettségszegési eljárásokat, támogatás-visszavonásokat a tagállamokban. Ugyanakkor a programozás és tervezés során életszerü mozgásteret lenne szükséges hagyni az 
olyan változások érvényre juttatásához, mint a 2008-ban indult gazdasági világválság is, melyre az éppen elfogadott hét éves kohéziós források felhasználásának programjaiban már alig lehetett reagálni. Disszertációm gyakorlati haszna kettős:

- a bizottsági szintet elérő módosítási javaslatokat annak érdekében fogalmazom meg, hogy tagországként képviselhessük a szabályozási rendszer további alakítása során,

- a tagállami szintủ módszertanok, javaslatok azt a célt szolgálják, hogy a hazai felhasználási szabályozás és intézmény-kialakítás, megvalósításmonitorozás a felelős, költség-takarékos, minőségi forrásfelhasználást eredményezzen.

\section{RÉSZ}

FOGALMI HÁTTÉR, SZAKIRODALMI KÖRNYEZET, MÉRÉSI GYAKORLATOK ÉS EREDMÉNYEK

\section{FEJEZET}

HATÉKONYSÁG, PARTNERSÉG, SZUBSZIDIARITÁS

\subsection{Fókuszált fogalomvizsgálat}

2009-ben Danuta Hübner, a regionális politikáért felelős biztos felkérésére Fabrizio Barca fogta össze azt a jelentést, mely a 2007-2013-as programozási időszak értékelését és a következő pénzügyi periódusra vonatkozó reformjavaslatokat fogalmazta meg (Barca [2009]). A raportőr határozottan foglal állást a minőségi költés mellett és egyenesen "szegényes vitának" aposztrofálta azokat a tagállamok közötti egyeztetéseket, ahol nem a hatékonyságról van szó a forráskialakítás témakörében. A 2014-2020-as programozási periódusra vonatkozó szabályozási rendeletek több ponton is használják a „hatásosság, eredményesség, hatékonyság” kifejezéseket, megerősítve az abszorpciótól történő elmozdulást a minőségi felhasználás felé (EP és ET [2013a,b,c,d,e,f,g]). Ugyanakkor a korábbiakhoz 
hasonlóan e joganyag sem ad kimerítő definíciót és lehatárolást a három fogalom kapcsán, jóllehet sok esetben elkülönülten használja. Az 52. és 68. bekezdés felsorolása is utal az eltérő tartalmakra:

„Az ESB-alapokból nyújtott támogatás eredményességét, hatékonyságát és hatását értékelni kell a programok kidolgozásának és a végrehajtás minőségének javítása érdekében, valamint annak felmérése céljából, hogy milyen hatást érnek el az intelligens, fenntartható és inkluzív növekedésre vonatkozó uniós stratégiában foglalt célokhoz viszonyítva, illetve adott esetben a programnak az érintett programterület bruttó hazai termékéhez (GDP) és munkanélküliségi rátájához viszonyított méretét figyelembe véve." (EP és ET [2013e] p.327).

„A Bizottság hatáskörét ki kell terjeszteni olyan helyszíni auditok és ellenőrzések elvégzésére, amelyek a hatékony és eredményes pénzgazdálkodással kapcsolatos kérdésekre összpontosítanak, annak érdekében, hogy az ESB-alapok teljesítményéröl következtetéseket lehessen levonni." (EP és ET, [2013e] p. 329)

A hatékonyság fogalma a magyar szakirodalomban is különféle értelmezést mutat. Egyes megközelítések szerint „hatékony egy program vagy projekt, ha szabályszerüen (a hatályos magyar és közösségi jog betartásával) és határidőben leköti, elkölti a rendelkezésre álló támogatási keretet”(Nagy [2010] p.117). Tekintettel arra, a többéves pénzügyi keretet szabályozó Európai Tanácsi rendelet 2. fejezet (Speciális eszközök) 11.cikke (Rugalmassági eszköz) mondja ki a 2014-2020 közötti időszakra alkalmazott n+3-as határidőt (ET [2013]), a határidőben történő költés is a szabályszerüség fogalmába tartozik, így a hatékonyság a szabályszerüséggel lenne azonos. Kijelenthető azonban az elmúlt évek tapasztalataiból adódóan, hogy a szabályok betartásával elköltött források felhasználása még nem feltétlenül hatékony, amennyiben azok „gyengesége” ahhoz vezet, hogy felesleges forrásokat fordítunk adminisztrációra, nyilvánosságra, előtanulmányokra, vagy a rosszul müködő intézményrendszerből adódó időveszteség okozta többlet-problémák ellensúlyozására. A fogalom ezért kiegészítésre szorul, valamint lehatárolásra az eredményesség és hatásosság fogalmától. E két utóbbinak, vagyis a célokhoz történő hozzájárulás vizsgálatának széles szakirodalma van nemzetközi szinten (Bradley [2006], Mohl és Hagen [2010]), Molle [2008]) és hazánkban is egyaránt (Kengyel [2008 és 2012], Nagy [2008.]; Czuriga [2009], 
Nyikos [2013], Varga -in't Veld J. [2010]). További álláspont szerint mérhető a nemzeti társfinanszírozás mértéke, az intézményrendszer müködési költsége és a projektgazdák müködési költsége a hatékonyság égisze alatt, melyből valóban vonhatóak le következtetések, de erre vonatkozó egységes számítás, metodika nem létezik (Kullmann [2013] p67). A hatékonyság szakirodalmában két munkásságot tartok kiemelésre méltónak, melyekre értekezésemben több alkalommal számíthattam referenciapontként. A glasgowi Strathclyde Egyetemen, az Európa Politikák Regionális Kutatóközpontja által létrehozott EoRPA elnevezésü kutatási konzorcium 2001. óta készít tanulmányokat az Európai Unió kohéziós támogatáspolitikájának építő kritikai megközelítésével. A teljes tagállami részvétellel - Magyarországról a Magyar Tudományos Akadémia Regionális Kutatások Intézete közremüködésével - megvalósuló kutatási együttmüködések során készült szintézisek számos esetben érintik a hatékony és takarékos felhasználás kérdéskörét (EPRC [2014]). A hazai szakirodalomban a Budapesti Corvinus Egyetemen 2008ban védte meg doktori értekezését Nagy Sándor Gyula „Az európai uniós támogatások hatékonyságának mérése" címmel, és azt követően is számos publikációjában vizsgálta a témát (Nagy [2008. 2010. 2013.]), jóllehet nála sem találkoztunk pontos definícióval, illetve mérési módszertanokkal is korlátozottan, mégis a tematikus fókusz nála jelentkezik elsőként és egyedüliként.

1.2 Szubszidiaritás és partnerség - nem csak elvek szintjén

Az EU regionális politikájának müködése 1989-ben újult meg, lényegi változás napjainkig nem történt a kohéziós alapok felhasználásának átfogó szabályozásában. Négy közös alapelvet határoztak meg, melyek figyelembe vétele nélkül nem lehet forrásfelhasználást megvalósítani. A koncentráció, a programközpontú megközelítés, a partnerség és az addicionlitás - vagyis az uniós támogatás kötelező kiegészítése, társfinanszírozása - elvei mentén épülnek fel a programozási és szabályozási keretek, valamint a megvalósítás során is elvárt érvényre juttatásuk. Valamennyi fenti sarokpontnak egy általános "szürőn" keresztül kell érvényesülnie, az Európai Unióról szóló szerződés 5. cikkében megjelenő szubszidiaritás elvének teljesülésével. Az elöször XI. Pius pápa 1931-ben kiadott szociális enciklikájában megjelenő fogalomnak különös aktualitást ad, hogy ezt az új egyházi útmutatást az 
1929-es gazdasági világválság ihlette, mely így fogalmazza meg lényegét a 79. és 80 . pontban (XI. Pius [1931]):

„amit az egyes egyének saját erejükből és képességeik révén meg tudnak valósítani, azt a hatáskörükből kivenni és a közösségre bízni tilos; éppen így mindazt, amit egy kisebb és alacsonyabb szinten szerveződött közösség képes végrehajtani és ellátni, egy nagyobb és magasabb szintű szerveződésre áthárítani jogszerütlenség és egyúttal súlyos bün, a társadalom helyes rendjének felforgatása (...). A kézenfekvő megoldás tehát az, ha az állami vezetés a kisebb jelentőségü teendők és problémák megoldását, amelyek őt amúgy is csak szétforgácsolják, átengedi az alacsonyabb szervezettségü csoportoknak (...). Az államférfiak legyenek meggyőződve arról, hogy minél tökéletesebben müködik a különböző társadalmi feladatokra szerveződő alakulatok rendje az említett szubszidiaritási elv érvényesítésével, annál nagyobb lesz az államhatalom tekintélye és cselekvésének hatásfoka, annál sikeresebb lesz és annál kedvezőbb helyzetbe kerül maga az állam is."

A fenti idézetekből kulcsszóként emelem ki a „cselekvés hatásfokát”, mert értekezésem középpontjában is ez áll, a fejlesztési források felhasználásának elősegítése módszertani javaslatokkal, intézményi és szabályozási ajánlásokkal, esettanulmányok és esetleírások alkalmazásával a jobb adaptáció és egzakt helyzetazonosítás érdekében.

A Világbank munkatársa, Thomas Farole az Európai Unió kohéziós politikájának intézményi kritikájában éles megállapításokat tett arra vonatkozóan, hogy a gazdasági növekedéssel elérhető felzárkózás csak több-szintü kormányzás és valódi szubszidiaritás együttesével valósítható meg. Ennek jó példáit már a szervezet több évtizedes nemzetközi tevékenysége mellett azonosították Tajvanban, Dél-Koreában, Szingapúrban, Írországban. A megállapítás közgazdasági alapja, hogy ugyanazon intézkedések eltérő technológiai és egyéb korlátok mellett teljesen különböző eredményeket hozhatnak, a humánerőforrás-fejlesztés és $\mathrm{K}+\mathrm{F}$ befektetés másféle hozzáadott értékét említve példaként a periferikus és a gazdasági centrumokhoz közelebb elhelyezkedő régiók összehasonlításában. A kutató kiemelte, hogy a gyenge intézményi berendezkedésű régiók nem hatékonyak a tudás és innováció megtelepítésében és támogatásában, melynek hátterében a rosszul megvalósított fejlesztés-politikák, elit csoportok járadékvadászata, és torzított támogatás-megítélés 
történik, amivel az eddig is előnyös pozícióban lévők helyzetbe hozása, valamint az egyenlőtlenségek további mélyítése valósul meg. A megfelelő intézményi környezet kialakításához a fent említett nemzetközi szakirodalom alapján négy feltételt azonosított, ezek (1) a proaktív nyitottság az újdonságokra, (2) a járadékvadászat és klientizmus korlátozása, (3) a tranzakciós költségek csökkentése, valamint (4) a koordináció. Európában kiemelten súlyosnak ítéli a korrupció problémáját fenti munkájában (Farole-Rodrígues-Pose-Storper [2011]). Kengyel szintén megerösíti Farole álláspontját, amikor így fogalmaz: „Már a jelenlegi gyakorlat alapján egyértelmü, hogy a kohézió erősítésének célját a több-szintű kormányzás (multi-level governance) modelljének keretében lehet a legjobban elérni". Az új programozási időszak kezdetén kiemeli a szubszidiaritás gyakorlati érvényesülésének elégtelen voltát, és felhívja a figyelmet a partnerség kiterjedtebb alkalmazásának szükségességére, a társadalmi és gazdasági szereplők együttmüködésének erősítésére (Kengyel [2015]).

A partnerség hivatalos megfogalmazását az Európai Unió Tanácsának 1999. június 21-i 1260/1999/EK. rendelete1 tartalmazza a következőképpen: „A partnerség magába foglalja a szoros együttmüködést az Európai Bizottság és minden tagország nemzeti, regionális, helyi illetve más szinten felelös hatóságai között, beleértve a tagállam meghatározott gazdasági és társadalmi partnereit is." Az ezt követő két újabb programozási időszakban is hasonló tartalommal várja el, hogy a partnerség megvalósuljon a támogatás-előkészítés, a megvalósítás (továbbá annak monitoringja) valamint az utólagos értékelések folyamán. Jóllehet az elméleti elvárások erősek, a gyakorlatban nincs semmiféle előírás arra vonatkozóan, hogy a tagországnak milyen mértékben és kiket kell bevonnia a programozási folyamat teljes, egy évtizednél is hosszabb időszakot lefedő vertikumában, indulva a tervezéstől egészen a többéves utólagos hatáselemzésekig.

Beszédes változás a 2014-2020-as programozási időszakra, hogy a teljes időszakot átfogó programozási dokumentum a Partnerségi Megállapodás elnevezést kapta, jóllehet szubnacionális szinten nincs garantálva a tényleges befolyásolás, a mérvadó részvétel lehetősége, ez teljes mértékben a tagországon belüli erőviszonyok függvénye. Kengyel [2015] a szabályozásnak a minőségre gyakorolt egyik hatásának feltételeként azt tekinti, hogy kizárólag a nemzeti kormány felelőssége, hogy mely 
intézményt vonja be és a fejlesztésben érdekelt helyi szereplőnek milyen beleszólási lehetőséget enged meg a programozás folyamán.

A Hétfa Kutatóintézet 2013-ban zárult, „Az EU-s támogatások területi kohézióra gyakorolt hatásainak értékelése" címmel készült vizsgálata a hatékonyságot oly módon közelítette meg, mely mindkét hipotézisemben szereplö fogalmat kiemeli a programozás kimenete szempontjából az alábbiak szerint (Balás [2013] pp.197-199):

„Amennyiben az egyes szakterületeken a szereplők feladataiban, felelősségében is konszenzust lehet teremteni, akkor ez (elosztási értelemben) hatékony erőforrásfelhasználásra ösztönözve segíti az európai felzárkózást, szinergiához vezet a fejlesztésekben, a közösen értelmezett dimenziókban csökkenti a belső egyenlőtlenségeket, a helyi adottságokra építve a fejlesztéseket segíti a harmonikus területi fejlődést, a közös megállapodásoknak megfelelően a szubszidiaritás elvei szerint hozza a döntéseket, illetve a helyi feladatokhoz mérten fejleszti a helyi intézményrendszert."

A Kutatóintézet a nemzetközi szakpolitikai dokumentumokban és a hazai fejlesztési tervekben ehhez kapcsolódóan négy értelmezési keretet azonosított (Balás [2013]p.2):

1. Harmonikus területi fejlődés - Magyarország térségei és települései a feltárt és különböző fejlesztési dokumentumokban megfogalmazott helyi/térségi adottságoknak/lehetőségeknek és problémáknak megfelelően részesültek-e az NSRK fejlesztési forrásaiból, illetve milyen mértékben használták e forrásokat a feltárt problémák megoldására?

2. Területi szinergiák érvényesülése $-\mathrm{Az}$ egyes térségekben a fejlesztési elképzelések a tervezés során kapcsolódtak-e egymáshoz, és a térségben megvalósult fejlesztések egymás kedvező hatásait erősítették-e, egymásra épültek-e és egymáshoz kapcsolódtak-e a végrehajtás és a fenntartás során?

3. Szubszidiaritás érvényesülése - Az egyes területi szereplők számára nyitott volt-e a fejlesztési forrásokból való részesedés lehetősége, a megvalósítandó fejlesztésekről a döntés - a tervezés és a végrehajtás során - a legalsó még kompetens területi szinten született-e? 
4. Területi kormányzás erősödése - Erősödött-e a helyi és az országos közötti területi szint (megye, régió) kormányzási képessége, nőtt-e a térségi fejlesztési szereplők közötti együttmüködés és bizalom?

\subsection{Alapfogalmak összegzése}

A disszertáció három alapfogalma - hatékonyság, partnerség és szubszidiaritás fenti szakirodalmi áttekintéséből azt látjuk, hogy az első fogalom definíciós hiánya megakadályozza a hipotézisek megállapításainak mérhetőségét. Ezért a következő fejezetben mind uniós szinten, mind az egyes tagállamok esetében áttekintem az erre vonatkozó mérési gyakorlatokat és elméleti hátteret, így oldva meg a teoretikai problémát. A másik két alapfogalom esetében ilyen probléma nem áll fenn, ezek gyökere visszanyúlik az Európai Közösség alapításának idejére, illetve az európai keresztény kultúra szerves részeként nem szükséges további teoretikai elemzésük, de a szakirodalmi kapcsolódásuk a hipotézisek bizonyításához elengedhetetlen, így ez végighúzódik a teljes értekezésen.

\section{FEJEZET}

\section{TAGÁLLAMI ÉS UNIÓS SZINTÜ HATÉKONYSÁGI MÉRÉSEK SZINTÉZISE}

\subsection{Tagállamok értékelési tapasztalatai}

A 2014-2020-as programozási periódus változásai, - különös tekintettel a csökkenő keretre és az eredményességi tartalék bevezetésére - újabb lendületet adtak az értékeléseknek. A hatékonyság fogalmi hiányának pótlása érdekében úgy jártam el, hogy megvizsgáltam mérésének módszereit uniós és tagországi szinteken egyaránt, utóbbiak közül a hazai értékelési gyakorlat összefoglaló elemzése hiánypótló a szakirodalomban.

A glasgowi Strathclyde Egyetemen, az Európai Regionális Politika Kutatási Konzorcium gondozásában 2014. szeptemberben megjelent tanulmány figyelemre méltó tagállami részvétellel foglalja össze a jelenlegi mérési gyakorlatokat a 
„Regionális politika hatékonyságának értékelése” című kiadványában (EPRC [2014]). A szakirodalomban számos tagállami mérési tevékenység csak azon része jelenik meg nemzetközileg is elérhető formában, ami az Európai Bizottság elvárásai szerint szükséges, vagyis a legtöbb esetben hatás-és eredményvizsgálatokat jelentő ex-ante, mid-term és ex-post értékeléseivel találkozhatunk az egyes operatív programoknak és a teljes időszakot lefedő programdokumentumoknak (korábban NSRK, jelenleg Partnerségi Megállapodás). A hatékonyságot is vizsgáló specifikus tanulmányok csak a tagállam anyanyelvén voltak elérhetőek, ezért ez a konzorciumi munka mérföldkőnek nevezhető az egyes tagállamok vizsgálatainak összehasonlíthatósága szempontjából.

A tagállamok, valamint Svájc és Norvégia részvételével elvégzett átvilágítás során azt látjuk, hogy nincs egységes álláspont az alkalmazandó értékelési gyakorlat tekintetében, országonként különböző álláspontot képviselnek a vizsgálat tárgyát és annak metodikáját tekintve, illetve annak térségi mélységében is azonosítható két eltérő nézet; míg nemzeti szintü méréseket végez Hollandia, Svédország és a NagyBritannia, addig Franciaország, Németország, Ausztria, Olaszország és Lengyelország szub-nacionális szinten közelíti meg a kérdést. Ennek oka természetesen a közigazgatási rendszer adottságait, hagyományait tükrözi. Azonosítható egy aktuális trend, mely beépítve a közigazgatásba, önálló intézményi szervként juttatja érvényre a mérések bonyolítását, és eredményeinek hasznosíthatóságát (kiváló példa a Brit Nemzeti Audit Hivatal és a lengyel Nemzeti Értékelési Egység felállítása, de hasonló folyamatok azonosíthatóak Ausztriában, Franciaországban, Írországban és Olaszországban is). Ezzel ellentétes folyamat, amikor a vizsgálatok elvégzését külső szereplők végzik, tanácsadók vagy akadémiai és egyetemi kutatók bevonásával, akik a függetlenség és az objektivitás erényeit birtokolják (Finnország és Németország hoz erre vonatkozó gyakorlatot). A módszertanok tekintetében is széles spektrum látható - egyenes következményeként az egységes bizottsági metodológia hiányának -, a tagállamok makro-ökonómiai modellezést, ökonometriai-statisztikai analíziseket, mikro-ökonómiai tényellentétes (kontrafaktuális) analíziseket, esettanulmányok készítését és elmélet-orientált értékeléseket végeznek (EPRC [2014] p8.).

Elsőként két, fent említett intézményi példát tartok kiemelésre méltónak, a brit és lengyel gyakorlatot, ahol a közigazgatáson belül önálló szerv felelős az értékelések 
végrehajtásáért. A kiemelés oka, hogy e két tagországban jelenik meg koncepcionálisan az összefogott, koordinált és következtetéseinek beépítéséért együttesen felelős intézményi szereplő megalkotása. Jóllehet hazánkban is létezett 2013-ig egy Nemzeti Fejlesztési Ügynökség, melynél látszólag egy kézben összpontosult a kohéziós források felhasználásának szinte teljes spektruma, az értékelések és mérések esetében csupán a technical assistance forrásból finanszírozott tanulmányok tartoztak felügyelete alá. Ezen kívül számos intézményi szereplő végzett monitorozást, ellenőrzést, mérést, és tagállami szinten hiányzik ennek koordinált megvalósítása.

Nagy-Britanniában a 2010. évi parlamenti választások óta a központi állami értékelések kevésbé kapnak nyilvánosságot, ugyanakkor számos párhuzamosan működő, külső szervezettől kapunk értékelési eredményeket. Az egyik kiemelt és aktív szereplője ezeknek az intézményi felülvizsgálatoknak a Nemzeti Audit Hivatal. A közel ezer fővel, a kormánytól teljesen függetlenített szervezet a Parlament Alsóházának tartozik beszámolási kötelezettséggel, mely nemcsak a kohéziós források, hanem valamennyi állami költés hatékonysági, eredményességi vizsgálatát végzi, közel évi hatvan „Értéket a Pénzért” jelentés elkészítésével. (NAO [2015])

A hatóság 2009-ben megújította stratégiáját, melyet a következő oldalon található ábra (1. ábra) jól szemléltet és foglalja össze tevékenységének spektrumát.

Kutatásom szempontjából a Hatóság tevékenységében az alábbi kiemelt fogalmakat azonosítottam:

- folyamatos takarékosság

- alkalmazható és fejlesztett tudás

- elszámoltathatóság

- helyi kormányzás új szerepének kialakítása

Az ábra alsó sorában nevesítik tevékenységségük mérésének fókuszpontjait:

- az intézményrendszer mennyire jól azonosította a kihívásokat

- a hatóság ajánlásainak elfogadása és alkalmazásának mértéke

- a kulcsszereplők azonosították-e a hatóság hozzáadott értékét

- a Parlament vagy egyéb döntéshozó igénybe vette-e a hatóság munkáját

- a hatóság tevékenysége eredményezett-e megtakarításokat az állami költésekben 
1. ábra: A brit Nemzeti Audit Hatóság stratégiája

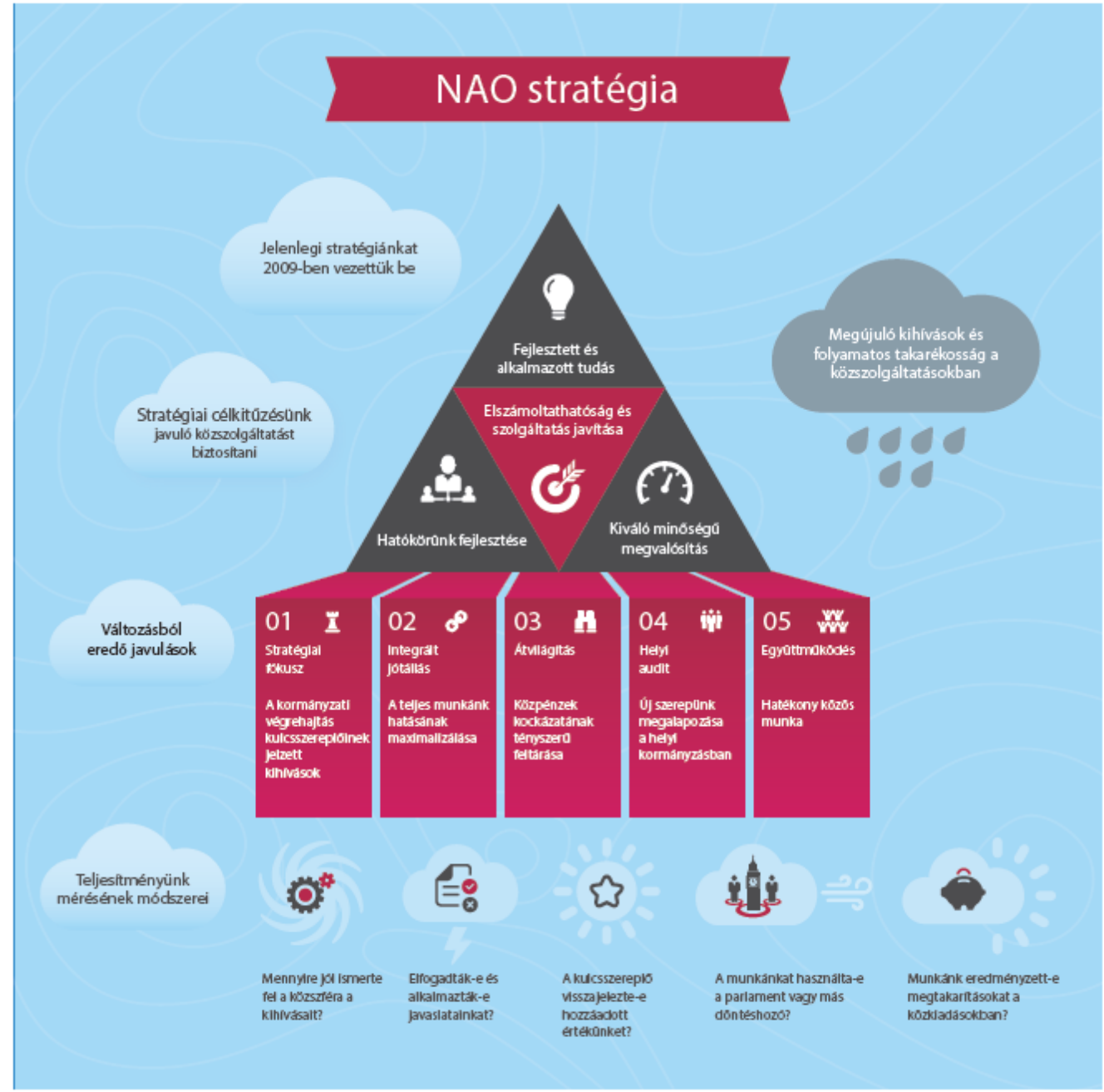

Forrás: http://www.nao.org.uk/wp-content/uploads/2014/12/NAO-Strategy-2015-162017-18-Infographic.pdf; Letöltés: 2015. május 28.

Megtakarításaik és a fenti mód valamelyikén elért eredményeik 2010. és 2011. évek összességében elérték az 1 milliárd Fontot az Alsóház által megrendelt, a „Regionális Növekedési Alap” címet viselő jelentés szerint (NAO [2012] p2.)

Szintén adaptálásra érdemes jellemzőket hordoz a kohéziós források felhasználásának értékelésére létrehozott lengyel Nemzeti Értékelési Egység. Az önálló intézmény az eddig megvalósult két programozási időszakot felölelve végzi munkáját a Regionális Fejlesztési Minisztériumon belül a Strukturális politika koordinációjáért felelős főosztály keretében, az Európai Bizottsággal szorosan együttmüködve. A mérések módját és tárgyát egy Irányító Bizottság határozza meg, melyet az egyes operatív programok irányító hatóságainak vezetői alkotnak. Az 
Irányító Bizottság felel az értékelések koordinációjáért, a folyamatok következetességéért, és dönt abban, hogy mely eredményeket hasznosítja, építi be a további megvalósításba. A folyamatos, vagy folyamatba épített értékelések szükségességét hangsúlyozzák, mely az elkészült fejlesztések jobb felülvizsgálatát és használható ajánlások megalkotását teszi lehetővé az aktuális megvalósítás gyakorlatába építve. A vizsgálatok transzparenciája érdekében az önálló weboldalt is felmutató szervezet müködését a technical assistance forrásából, vagyis a támogatások adminisztratív bonyolítását lehetővé tevő finanszírozási keretből végzik. A két programozási időszak felülvizsgálatának módja egybeesik, melyben hat fókuszpontot alkottak az alábbiak szerint:

- társadalmi-gazdasági fejlesztések hatása

- infrastrukturális fejlesztések

- gazdasági innováció

- humán erőforrás fejlesztés

- regionális és helyi fejlesztések

- közigazgatási kapacitásfejlesztés és a jó kormányzás megvalósítása

A mérések kétszintűek, a fenti tematikák alapján operatív programokat átívelő tanulmányok, valamint az egyes programok önálló felülvizsgálata is megvalósul. A munka elvárt kimenete a mérési standardok fejlesztése, valamint az elemzések minőségi javulása. A mérésekhez a külső szakértők, tanácsadók bevonását egy erős belső együttmüködési munkával hajtják végre, és az eredmények nyilvánosságának biztosítását is ez a szervezet végzi. Ahogyan fogalmaznak, a folyamatos és folyamatba épített értékelés lehet a kulcsa a hatékony felhasználásnak Lengyelországban (Krajowa Jednostka Ewaluacji [2009]).

Az Európai Regionális Politika Kutatási Konzorcium közreműködésével vált nemzetközi szinten ismertté az a finnországi felülvizsgálati gyakorlat, mely a program-szintű értékelésre mutat figyelemre méltó példát és tesz az értekezésemben továbbgondolásra alkalmas megállapításokat. A Ramboll Management Consulting szervezet két Regionális Stratégiai Program 2012-ben végzett értékelő vizsgálata alapján komplex hatás-és eredményességi mutatókat mért, valamint kitért hatékonysági kérdésekre is. Utóbbi esetében az alábbi megállapításokat tette (EPRC [2014] p27): 
- a programhatékonyság szempontjából szükséges bevezetni egy olyan modellt, mely biztosítja az előre-jelezhetőséget, a nyomon követhetőséget és az értékelést is, valamint a rugalmasabb és jövö-orientált megközelítését a regionális tervezésnek.

- mérhetőség nehézségét abban látja, hogy a programok számos helyen használják a „megnöveli, javítja és hatással volt rá” kifejezéseket, ugyanakkor nincs konkrétum ezek definiálására, monitorozására, értékelésére.

Megítélésem szerint a jelentés két, eddig máshol nem használt hatékonysági szempontot említ programszinten, az előre-jelezhetőséget, és rugalmas alkalmazkodást. A jelzőket hazai példában is tetten érhetjük a negyedik fejezetben önálló esettanulmányként bemutatott Széchenyi 2020 Ügyfélszolgálat intézményi szereplő tevékenységében.

A glasgowi kutatási konzorcium rávilágított egy másik előremutató tagállami példára, a Hollandiában évente készülő, ún. EU-Trend Report gyakorlatára (EPRC [2014] p19), melynek keretében új területi alapú megközelítésben az OECD kezdeményezésére készíti a Holland Számvevőszék elemző jelentését. A tárgyévet követő év februárjában megjelenő jelentések a Kohéziós alapok pénzügyi előrehaladásába is betekintést engednek, ugyanakkor az eredményesség és hatékonyság szempont szerinti felülvizsgálatot is jelent az aktuális felhasználás tükrében. A tájékoztatás mellett tartalmaz még ajánlásokat, melyek közvetlen visszacsatolást tesznek lehetővé a megvalósítás és az irányelv-alkotás folyamatába. A kormány nyomon követi a számvevőszék javaslatait és írásban reflektál azokra. A 2014. év holland felhasználásra vonatkozó javaslatai tanulságosak lehetnek a magyar felhasználás számára is, így a megállapítások bemutatását a hazai trendek összevetésével foglalom össze (Rekenkamer [2014]):

- A több láthatóság elve: ez a programok és projektek szintjén is megjelenő elvárás a lakosság számára kívánja jobban transzparensé tenni a projektkiválasztást és a megvalósítások eredményét.

- Költség-átalányok kidolgozása: a projektek hatékonyságának összehasonlíthatósága érdekében javasolt metodika több tagállamban is megjelenik. Hazánkban a fajlagos költségek alkalmazása a 2007-2013-as 
programozási időszak számos operatív programjában megjelent, kiemelten a regionális és energetikai, humán-infrastruktúra fejlesztését megvalósító programokban - ugyanakkor ezek egységesítése és valamennyi programon átívelő következetes alkalmazása a központosított Nemzeti Fejlesztési Ügynökség összevonási szándéka ellenére sem történt meg. Egy-egy kedvezményezett azt tapasztalhatta, hogy különböző programokból elnyert fejlesztéseiben eltérő költség-képzésre volt szükség. Sajnos sem uniós, sem tagállami szinten nem látható egy egységes fajlagos költség útmutató kidolgozása, jóllehet a megvalósítás egyre bővülő spektrumát látva elengedhetetlen feltétel lenne a takarékos, megfelelő ár-érték arányú fejlesztések megvalósításához.

- Értéket a pénzért elv: a holland javaslat szerint ne csak az adott alap társfinanszírozási mértéke legyen irányadó, hanem a további, hazai társfinanszírozások is. A javaslat megítélésem szerint is fontos és adaptálható, mert az addícionalitás elve alapján a központi költségvetés kötelező hazai társfinanszírozási arányán túl léteztek/léteznek itthon is a költségvetésből pályázható önerő alapok (ezt az együttes támogatásvizsgálat kimutatja), de vizsgálandó az önkormányzati vagy vállalati saját erő mértéke.

- Az EU Trend Report javaslata szerint a programszinten elérni kívánt eredményeknek jobban kell kötődniük az egyes fejlesztésekhez, vagyis a köztes indikátorok lehetőség szerinti kivezetése szükséges lenne. A hazai megvalósításban éppen fordított jelenség tapasztalható, amikor elsősorban már a 2014-2020-as programciklus során a foglalkoztatás növekedését és/vagy megőrzését várja el a nem foglalkoztatás-típusú fejlesztésektől is. Szemléletes példa erre a meglévő iparcsarnokok megújítása, mely többletkapacitást ugyan nem eredményez, de munkahelymegőrzés vagy bővítési kötelem része lesz a támogatási szerződésnek. Az indikátoroknak máris egy kettősségét láthatjuk, mert nem a fejlesztéssel létrehozott mutatók a fontosak, hanem a támogatás-elnyerésének érdekében vállalt kötelmek, mint az energia kibocsátás, vagy foglalkoztatás, azon belül a hátrányos helyzetüek foglalkoztatása

- Az indikátorok alkalmazásának módjára született holland javaslatok összecsengenek a hazai operatív programok ex-ante értékelésének 
javaslataival. Ahogyan az Ernst \& Young vezette értékelö konzorcium az EFOP értékelő jelentésében itthon is megállapítja a beavatkozások és indikátorok közötti kapcsolatok hiányát, valamint annak veszélyét, hogy megismétlődhet a most záródó programozási ciklus azon problémája, hogy a költségvetés dominál a tartalmi értékelés és tartalmi megfelelőség helyett (Ernst\&Young [2015]).

- Lényegi az a holland megállapítás, mely szerint a projektszelekció versenyszempontú megközelítése akkor javasolt, ha az a hatékonyság/eredményesség érdekében történik, és nem egyszerüen a beérkezési sorrend alapján történő döntést eredményezi. A magyar projekt-kiválasztási gyakorlat sajnos ugyanígy hordozza a jelenséget és a problémát is. A 2007-2013-as programozási periódus projekt kiválasztási metodikájának meghatározó része a nyílt eljárások alkalmazása, melynél a beérkezési sorrend szerinti bírálat szélsőséges formákat öltött. Ennek esetleírását az 5. rész tartalmazza majd, továbbá a 6. részben a kontrafaktuális vizsgálatom is a nem megfelelő projektszelekciós eljárás alkalmazásának következményeit vizsgálja.

- A jelentés felhívja a figyelmet arra az aktuális veszélyre, mely a holland 2000-2006-os programozási időszakban is megfigyelhető jelenség volt, miszerint a célok alultervezetté váltak, a megőrzés-típusú projektek domináltak a fejlesztés-típusúakkal szemben. Ezt az eljárásrendek és pályázati tartalmak tettek lehetővé. Az indikátorok és kötelező vállalások összemosódása itthon is azonosítható, de a „kilengés” mindkét irányba megjelent, vagyis nem csak alultervezett adattokkal, de túlzó elvárásokkal is készültek projektet, különös tekintettel a „soft-típusú” tartalmakra. Gyengeség a túlzott óvatosság a célértékek meghatározásában is, vagyis a programozás során beállított célindikátorok a megvalósítás során többszörösen teljesülnek programszinten az ERFA és ESZA alapok tekintetében Hollandiában, vagyis nem értelmezhetőek a hatékonyság fokmérőjeként. Jól mutatják ezt a jelenséget hazánkban is a HEFOP és a TÁMOP programok eredményindikátorai.

- Hatékonysági problémákat hordoznak az indikátorokra vonatkozó további fogyatékosságok, mint a fogalmak tiszta tartalmának hiánya és az indikátorok programmegvalósítás közbeni változása. Elöbbi esetben a 
fogalom a kedvezményezett szemszögéböl gyakran eltér az irányító hatóságok alkotta „számítási eszközöktől”, így a számon kérhetőség is sérül, az utóbbi probléma a koherenciát, összemérhetőséget és a fajlagos mérést is korlátozza. Az értéket a pénzért elv a stratégiai célokban ugyan mindig hangsúlyos szerepet kap, majd a megvalósítás során mégis döntően elsikkad, mely normaköltségek, reális költségarányok meghatározásának hiányából ered. Erre vonatkozóan a hazai gyakorlatban is megjelenő belső projektszázalékok olykor meglepően megengedőek voltak, amire a 4. fejezetben a nyilvánosság, közbeszerzés, menedzsment belső költségarányainál részletesebben kitérek.

- A holland ex-post értékelések abban merülnek ki, hogy a célindikátorok vizsgálata történik meg, ugyanakkor a projekt hatékonyságának utólagos vizsgálata elmarad. A hazai megvalósításban szintén alkalmazandónak tartanám a projektszintü felülvizsgálatot. Jóllehet a kedvezményezettek kizárása súlyos szabálytalanság esetén 5 évre megtörténik, ugyanakkor egy árnyaltabb minősítésre is szükség lenne a megvalósítás minőségének értékelésével. Ennek következménye a további pályázási lehetőségek korlátozása lehetne. Ez érintheti a kedvezményezettet, ugyanakkor a külső menedzsment céget is, így mindketten a minőségi megvalósításra és együttes megoldásra lennének kötelezettek.

Németország mérési gyakorlatában a hatékonyság vizsgálata alatt azt értik, hogy a regionális politikai célok (munkahelyteremtés, új cégek letelepítése, működő tőke beruházások növelése, új együttmüködési hálózatok kiépülése) hogyan teljesültek. Ennek mérésére számos módszert alkalmaznak, melyek közül egy mikroökonómiai tényellentétes vizsgálatot tartok részletesebb bemutatásra érdemesnek, tekintettel arra, hogy saját kutatásomban is domináns helyet foglal el egy kontrafaktuális összehasonlító módszertant alkalmazó mérés. A Gazdasági és Energetikai Szövetségi Minisztérium a Dortmundi Egyetem közremüködésével mérte a „Regionális Gazdasági Struktúra Javításáert" létrehozott munkacsoport tevékenységének hatékonyságát, a tevékenységük szükségességének további létjogosultságát, fókuszát (BMWE [2013a]). A vizsgálati módszertan a támogatott és nem támogatott vállalkozások összehasonlítását jelentette a munkahelyteremtés és bérstruktúra alakulásának mérésében. A 2009-2010-ben zajló, illesztési metodikát alkalmazó 
eljárásban 4622 céget hasonlítottak össze. A résztvevő cégek a 2000-2006-os programozási időszakban támogatást elnyerő cégek, valamint a hasonló karakterisztikájú, de nem támogatott vállalkozások csoportja. A metodika olyan világos eredményeket hozott, - kutatásom szempontjából a részletes kimenetek mellőzhetőek, de említésre méltó tény, hogy a támogatott cégeknél 1,9\%-al növekedett a munkahelyek száma, míg a nem támogatott cégek esetében 6.9\%-os csökkenés volt tapasztalható - hogy a módszert alkalmazva 2013-ban ugyanezt az illesztéses vizsgálati módszertant alkalmazták (BMWE [2013b]).

A cseh értékelési gyakorlatból a Prágai Közgazdaságtudományi Egyetem Vezetéstudományi tanszékének két munkatársának munkáját tartom kiemelésre méltónak, akik bemutatták a DID módszert (Potluka- Bruha [2014]). A különbség a különbségben (difference-in-difference) metodikával mérték a támogatott-nem támogatott cégeket, intézményeket, valamint fejlesztés előtti és utáni méréseket végeztek. A hatodik fejezetben bemutatásra kerülő módszerem egy speciális DID, mert összehasonlítja a kiemelt eljárásrend szerinti projektszelekciós kimenetet (ez ugyan terv szinten maradt, de pontos projekttartalommal) a tényleges kimentettel, ami a nyílt projektszelekciós eljárás alkalmazásával valósult meg. A vizsgálat megítélésem szerint nem csak a két eljárás közötti különbségre világít rá, hanem arra is, hogy a 2007-ben, a teljes végrehajtási rendszer ismerete nélküli „csupasz” projekttartalomra milyen járulékos egyéb költségterhek rakódtak, valamint milyen egyéb - nem tervezett, nem remélt - eredmények születtek pozitív és negatív előjellel egyaránt.

Sajnos a klasszikus DID eljárás azon része esetemben kizárható, hogy a tervezett fejlesztések az uniós forrás nélkül is, saját forrásból megvalósultak volna, így nem a klasszikus támogatott-nem támogatott vizsgálati módszer kerül alkalmazásra.

Vizsgálatom módszere a fentiek alapján elmélet-alapú elemzést jelent, mert nem csak a két vizsgált állapot közötti különbséget mutatom ki, hanem a hogyan kérdésre kapunk választ. Ennek hipotézise megítélésem szerint az adekvát partnerséget és szubszidiaritást nélkülöző eljárással lefolytatott tényleges projektszelekció, valamint a további, nem hatékonyság-orientált megvalósítás hozadéka. 
2.2 Uniós szintű mérési gyakorlatok, elvárások

Az Európai Bizottság Regionális Politikai Főigazgatóságának elismerésével tevékenykedik az - 1999-től csak on-line módon publikáló - a társadalmi-gazdasági fejlesztések felülvizsgálatában és kiértékelésében útmutatásokat adó szervezet (továbbiakban az angol mozaiknevén: EVALSED). A 20 éves munkásságra visszatekintő, hiánypótló tevékenységet végző szervezet 2013-ban adott ki egy útmutatót és módszertani ajánlásokat tartalmazó kiadványt, melyben az alábbi kérdésekhez köti a hatékonyság vizsgálatát (EVALSED [2013]):

1.) Milyen mértékben sikerült elérni a célt?

2.) Az alkalmazott beavatkozások és eszközök elérték-e a kívánt célt?

3.) Más eszközökkel jobb eredményt lehetett volna elérni?

A kontrafaktuális vizsgálatomban mindhárom kérdést körbejárom, kiemelten az utolsót, hogy egy másik projektszelekciós eszközzel jobb eredményt lehetett volna-e elérni.

Kijelenthető, hogy önállóan egy szakirodalom sem összegzi a hatékonysági értékelések szükséges tartalmát, a hatékonyság mérésének módszertanát nyilvánvalóan a teoretikai hiányosságok miatt, - ugyanakkor számos tagország programértékelő vizsgálatainak szerves részét képezi ez a szempont is. Ezt látjuk uniós szinten is, ahol az Európai Bizottság a hatékonysági szempontot a kohéziós források felhasználásának monitorozási és értékelési módszertani útmutatójában jeleníti meg, összhangot várva el az uniós végrehajtási és pénzügyi szabályozás kereteivel (EC [2013]), ugyanakkor ebben sem jelennek meg számon kérhető, a minőségi felhasználást „kikényszerítő” szabályozási elemek és kötelezően használandó megoldások, jó gyakorlatok.

2.3 Értékelések összefoglaló szintézise és a hazai tíz éves gyakorlat összehasonlító bemutatása

Az egyes tagállamokban alkalmazott értékelő gyakorlatok összefoglalásához a glasgowi egyetemi kutató konzorcium értékes összegzéseket és összehasonlításokat 
adott, melynek szintetizáló kivonatát és a hazai sajátosságokkal történő kiegészítését készítettem el az alábbi táblázatban (1. táblázat) (EPRC [2014] pp22-23).

1. táblázat: Mérési és értékelési gyakorlatok tagállami összehasonlítása

\begin{tabular}{|c|c|c|c|c|}
\hline Országok & MEGVALÓSÍTÓK & TERÜLETI SZINT & TÁRGYA & FÓKUSZA \\
\hline Ausztria & $\begin{array}{c}\text { tanácsadók és } \\
\text { egyetemek } \\
\text { alkalmanként állami } \\
\text { intézmények }\end{array}$ & (döntően) tartományi & $\begin{array}{c}\text { egyéni értékelések } \\
\text { hiánya } \\
\text { (összevontan más } \\
\text { mérésekkel) }\end{array}$ & hatásosság \\
\hline Finnország & $\begin{array}{c}\text { főként külső } \\
\text { (objektivitás okán, } \\
\text { de a hozzáadott érték } \\
\text { olykor } \\
\text { megkérdőjelezhető) }\end{array}$ & nemzeti és regionális & $\begin{array}{l}\text { eszközök és programok } \\
\text { (regionális stratégiai } \\
\text { programok, egyedi } \\
\text { projektek) }\end{array}$ & eredményesség \\
\hline Franciaország & $\begin{array}{l}\text { változatos: politikusok, } \\
\text { civil szervezetek, } \\
\text { külső kutatók, kevés } \\
\text { számú tanácsadó } \\
\text { bevonásával hoznak } \\
\text { létre a minisztériumok } \\
\text { értékelő } \\
\text { munkacsoportokat }\end{array}$ & nemzeti és regionális & $\begin{array}{c}\text { teljes témák (pl. } \\
\text { vállalkozás-támogatás) } \\
\text { a Közszféra } \\
\text { Modernizációjáért } \\
\text { felelős Minisztérium- } \\
\text { közi Bizottság dönt az } \\
\text { értékelésekről, } \\
\text { kormányzati } \\
\text { témaválasztás a } \\
\text { programjukhoz } \\
\text { illesztetten }\end{array}$ & $\begin{array}{l}\text { hatás és } \\
\text { hatékonyság }\end{array}$ \\
\hline Németország & $\begin{array}{l}\text { tanácsadók és } \\
\text { egyetemek }\end{array}$ & $\begin{array}{c}\text { helyi szintű } \\
\text { értékeléseket } \\
\text { föderálisan kezelik, } \\
\text { az EU Bizottság } \\
\text { tartományi szinten } \\
\text { értékel }\end{array}$ & $\begin{array}{l}\text { vállalkozás-fejlesztés } \\
\text { eszköz-specifikus } \\
\text { értékelése }\end{array}$ & $\begin{array}{c}\text { hatás, } \\
\text { hatékonyság } \\
\text { értéket a } \\
\text { pénzért }\end{array}$ \\
\hline Olaszország & $\begin{array}{l}\text { tanácsadó és } \\
\text { egyetemek } \\
\text { regionális és nemzeti } \\
\text { értékelő egységek }\end{array}$ & $\begin{array}{l}\text { nemzeti és regionális } \\
\text { (az elmúlt években } \\
\text { mindinkább regionális) }\end{array}$ & $\begin{array}{c}\text { változatos: téma szerinti } \\
\text { és programközpontú } \\
\text { értékelések }\end{array}$ & $\begin{array}{l}\text { hasznosság és } \\
\text { hatékonyság }\end{array}$ \\
\hline Hollandia & $\begin{array}{c}\text { tanácsadók, kutató } \\
\text { intézetek }\end{array}$ & nemzeti & $\begin{array}{l}\text { Változatos: egyedi } \\
\text { eszközök, teljes } \\
\text { programok, témák }\end{array}$ & $\begin{array}{l}\text { hatásosság, } \\
\text { eredményesség } \\
\text { hatékonyság }\end{array}$ \\
\hline Lengyelország & $\begin{array}{c}\text { tanácsadók (főként) és } \\
\text { egyetemek } \\
\text { belső:Nemzeti Értékelő } \\
\text { Egység } \\
\text { (növekvő szerep) }\end{array}$ & $\begin{array}{c}\text { nemzeti és } \\
\text { növekvő regionális }\end{array}$ & $\begin{array}{c}\text { Változatos: a } \\
\text { támogatások } \\
\text { kedvezményezettjei } \\
\text { szerinti; eszközök, } \\
\text { programok }\end{array}$ & $\begin{array}{l}\text { hatásosság és } \\
\text { megvalósítás }\end{array}$ \\
\hline
\end{tabular}




\begin{tabular}{|c|c|c|c|c|}
\hline Svédország & $\begin{array}{l}\text { nemzeti ügynökség ( } \\
\text { Tillväxtanalys)az } \\
\text { értékelések } \\
\text { megszervezéséért } \\
\text { felelős, mely külső és } \\
\text { belső egyaránt lehet }\end{array}$ & nemzeti & $\begin{array}{c}\text { teljes program, } \\
\text { nagyprojekt (1 M Euro } \\
\text { feletti), megvalósító } \\
\text { szervezetek } \\
\text { felülvizsgálata }\end{array}$ & $\begin{array}{l}\text { hasznosság és } \\
\text { hatékonyság }\end{array}$ \\
\hline Nagy-Britannia & $\begin{array}{c}\text { tanácsadók és belső: } \\
\text { NAO }\end{array}$ & nemzeti (várható lokális) & $\begin{array}{l}\text { Változatos: egyedi } \\
\text { eszközök, teljes } \\
\text { programok, témák }\end{array}$ & $\begin{array}{c}\text { értéket a } \\
\text { pénzért, } \\
\text { hatékonyság, } \\
\text { megvalósítás }\end{array}$ \\
\hline Magyarország & $\begin{array}{c}\text { külső: tanácsadók } \\
\text { állami:KEHI, ÁSZ [2013], } \\
\text { PSZÁF (NAV) }\end{array}$ & nemzeti & $\begin{array}{l}\text { témák, teljes programok } \\
\text { (Bizottság számára } \\
\text { kötelező: OP-ex-ante, } \\
\text { mid-term és ex-post), } \\
\text { támogatás-kezelők } \\
\text { értékelése }\end{array}$ & $\begin{array}{c}\text { eredményesség } \\
\text { megvalósítás }\end{array}$ \\
\hline
\end{tabular}

Forrás: saját készítés az EPRC [2014] p16-17. adatai, valamint saját készítés a hazai jellemzők integráns bemutatásával

A hatékonyság fogalmi hiányának pótlása érdekében végzett szintetizáló munkám során, az egyes tagállamok értékelési gyakorlatát vizsgálva azt láthatjuk, hogy monitorozási tevékenységük megjelenik mind az intézményi müködés, mind a program-és projektalkotás/kiválasztás szintjén is. A projektszintủ vizsgálatok szinte kizárólag eredményességi kérdésekre terjednek ki, és aggregált hatásmechanizmusokra. Megítélésem szerint azonban projektszinten is valós igény a hatékonyság vizsgálata, ahol vizsgálni szükséges, hogy:

- egy adott fejlesztés - függetlenül annak infrastrukturális vagy „szoft” tartalmától - megvalósítása miért szenvedett késedelmet (a programozási időszak végéhez közel eső megvalósítás időbeni elhúzódása abszorpciós veszélyeket hordoz);

- a tervezett költségvetéshez képest hogyan alakult a tényleges megvalósítás során jelentkező forrásigény;

- milyen járulékos költségek terhelték a fejlesztést (ezek létének és mértékének vizsgálata az intézményrendszer müködési problémáira, és jogszabályi előfeltételek túlzó vagy nem megfelelő kialakítására reflektál(hat)); 
- a tervezett tartalmon túl milyen többlet-tevékenységek valósultak meg kötelező vagy opcionális jelleggel.

A programszintü értékelésekben megjelennek hatékonysági szempontok, ezek között az előre-jelezhetőséget, rugalmasságot, jövő-orientált tervezést, folyamat-közbeni monitorozást, átláthatóságot, beépíthető visszacsatolást és értékelést várva el az intézményrendszertől, valamint fajlagos költség-meghatározást, legitim partnerséget, adekvát szubszidiaritást és a cél elérése érdekében legmegfelelőbb eszközválasztás a projektkiválasztás területén az intézményrendszert kísérő járadékvadászat és információmonopólium minimalizálásával.

A glasgowi kutatási konzorcium úttörőnek nevezhető munkájában kritikai megközelítéssel kell kezelnem azt a megállapítást (EORPA [2014.]p.39), mely szerint nincs elegendő pénzügyi és humán-erőforrás az értékelések elvégzésére. Megítélésem szerint mindkét esetben „csak” felhasználási probléma van, vagyis a technical assistance forrás megfelelő és koordinált költése elegendően tág teret biztosít ezeknek a méréseknek, felülvizsgálatoknak, függetlenül attól, hogy azt külső szakértők, intézményi munkatársak vagy a kettő kombinációjából képződő munkacsoportok végzik, ahogy a fenti tagállami gyakorlatok széles skálája mutatta. A humán-erőforrás még oly módon is kiegészíthető, hogy az egyes programkezelési feladatok ésszerűsítése, racionalizálása - ami önmagában is intézményi hatékonyságot eredményez - által munkaerő átcsoportosítást tesz lehetővé: Ennek különösen teret ad az e-pályázás, e-elszámolás rendszerének fejlesztése. Ez hazánkban kiemelkedően magas színvonalon valósul meg uniós összehasonlításban is. A fenti gondolat mellett nem hanyagolható el azonban az a megállapításuk, mely szerint a tagállami mérési gyakorlatok alapján a legfőbb hatékonysági korlátnak az intézményi problémákat azonosítja az alábbiak szerint (EPRC [2014] p39.):

- "bizonyítékokon-alapuló" politikák tapasztalatának hiánya, vagyis a kohéziós politika alkotás és a megvalósítást mérö értékelések eredményei közötti kapcsolat hiánya eredményezi a nem hatékony programokat azzal, hogy nem a hatékonyság vizsgálatára szabják, ezért homályos vagy az eredeti szándékkal éppen ellenkező eredményt elérő kezdeményezések születhetnek.

- a méréseket gyakran rövid-távú kötelezettségek - lásd. az Európai Bizottság értékelési elvárásait - vagy politikai információhiány szüli, nem 
perspektivikus igény. Ez szintén korlátozza a mérések hatékonysági szempontú tartalmát, vagy teljesen mellőzi is azon jelenségek nevesítését, melyek ilyen irányú tapasztalatokat jelentenek.

- megfigyelhető egy politikai idegenkedés és elővigyázatosság is, mely a hatékonysági problémák feltárását - különösen azok nyilvánosságra hozatalát nem tartja szükségesnek.

A fentiek alapján szükségesnek tartom bemutatni a következő fejezetben, hogy a szakirodalom milyen összefüggést tulajdonít a hatékony felhasználás és az intézményrendszer müködése, kialakítása között. Ezt követően a nemzetközi jogi szabályozás hatékonyság-fókuszú elemzését végzem, valamint a 2014-2020-as programozási periódusra vonatkozó intézményi/tervezési/megvalósítási kötelmeket, melyek behatárolják, determinálják a megvalósítási problémákat. Az értekezésemben a nemzetközi összehasonlítás mellett erős hazai fókusz jelenik meg az elmúlt évtized hazai intézményrendszeri változásainak értékelésével a $\mathrm{H} 1$ hipotézis bizonyítása érdekében.

Befejező gondolatként a mérhetőség nehézségére térek ki, mely valamennyi fent említett nemzetközi és hazai szakirodalomban megjelenik, nemcsak a hatásosság és eredményesség kérdését illetően - külön fejezetben térek ki az indikátorok problematikájára -, hanem a minőségi megvalósítás mércéjeként is. Ennek hazai példájaként egyik sokatmondó eset az a városvezetői megközelítés, mely szerint egy Regionális Operatív Programban megvalósult pont-szerü településfejlesztési beruházás keretében a közpark megújítására azért volt szükség, mert „rendre nevel”. Nem mutatható ki egyéb hozzáadott gazdasági érték, új vállalkozások betelepülése, csökkenő bünesetek száma, több társadalmi esemény megvalósítása, egyszerüen „csak” a jelenlegi lakosság és jövő generációja igényesség-szintjének az emelése. Ezt cáfolni nem lehet, s talán nem is szükséges, de mérése alig megoldható. 


\section{FEJEZET}

\section{AZ INTÉZMÉNYRENDSZER SZEREPE A TÁMOGATÁSOK HATÉKONY FELHASZNÁLÁSÁBAN}

\subsection{Az intézményrendszer és a hatékonyság szakirodalmi kapcsolata}

A támogatások nominális és hatékony lehívásának egyik kulcsa az ezt szabályozó intézményrendszer, mind tagállami, mind uniós szinten egyaránt. Ederveen és társai [2006] egyenesen azzal a kijelentéssel élnek, miszerint a strukturális alapok a megfelelő intézményrendszerrel rendelkező államokban hatékonyak. Charron és szerzőtársai tanulmánya [2012] azzal egészítette ki a megállapítást, hogy az országok, régiók kormányzási és közigazgatási színvonala is hatással van a kohéziós források hatékony és eredményes felhasználási kapacitására. Burnside és Dollar [2000] által szélesebb értelemben vett „támogató politikai környezettel” azonosíthatjuk a felhasználásért felelős intézményrendszert, megközelítésükből ebben az esetben müködik legjobban a kohéziós politika. A fenti állásponttal megegyezően a lengyel szakértő, Kozak az „Európai regionális politika menedzsmentje Lengyelországban a csatlakozást követő kezdeti időszakban" címet viselő tanulmányában így fogalmaz (Kozak [2006] p89):

„Az új 2007-2013-as tervezési periódusra történő felkészülésben az egyetlen küldetés a csökkentés, az intézményi rendszer kialakításának javítása egy teljesen új rendszer megalkotása helyett, a lengyel fejlesztéspolitikában egy hosszú távú perspektíva megalkotása és elérhető célok megvalósítása az uniós alapok segítségével és nem megfordítva.(...) és nem az a fontos, hogy mennyi pénzt költöttünk, hanem hogy mit értünk el általa."

A magyarországi közigazgatási tapasztalatokkal rendelkezö Nyikos a regionális politika hatékonyságát szintén az irányító, menedzselő szervezetek müködésének hatékonyságától, illetve általában az igazgatási rendszer működésének minőségétől teszi függővé, kiegészítve azzal, hogy a korrupciós és diszkriminációs jelenségek ezt jelentősen ronthatják (Nyikos [2013]). Az intézményi környezet müködésének módja 
és a felhasználás hatékonysága közötti összefüggést számos további tanulmány támasztja alá a hazai (Perger [2010]; Kengyel [2012 és 2015.] Nyikos [2011 és 2013]) és a nemzetközi szakirodalomban egyaránt (Farole - Rodrígues-Pose Storper [2013]; EPRC [2014]).

E fenti szakirodalmi háttér alapján axiómaként kimondható, vagyis disszertációm null-hipotézise, hogy a kohéziós források felhasználásának intézményrendszere, annak kialakítása és müködésének módja determinál hatékonysági problémákat. Az intézményrendszer kialakításának és müködésének egyik eredője a bizottsági jogszabályi keretrendszer. Ezek alapján önálló alfejezetként dolgoztam ki az intézményrendszert meghatározó jogszabályi háttér hatékonyság-központú megközelítésének elemzését. Az elemzés három fázisban történt meg az ok-okozati összefüggések feltárása érdekében; az első a huszonöt hónapos egyeztetési folyamatok érdekütközéseit, érdekcsoportjait mutatja be, míg a második szakasz a kialakult szabályozási keretben véglegessé vált hatékonyság-fókuszú sajátosságokat elemzi. Végül a magyarországi programalkotási kihívások, folyamatok bemutatása történik a tagállami fókusz érdekében.

3.2 A 2014-2020-as uniós jogszabályalkotás a minőségi költés jegyében intézményi összefüggések

\subsection{1 Érdekcsoportok kereszttüzében}

2009-ben Danuta Hübner, a regionális politikáért felelős biztos felkérésére Fabrizio Barca fogta össze azt a jelentést, mely a jelen programozási időszak értékelését és a következő pénzügyi periódusra vonatkozó reformjavaslatokat fogalmazta meg (Barca [2009]). A raportőr határozottan foglal állást a minőségi költés mellett és egyenesen "szegényes vitának" aposztrofálta azokat a tagállamok közötti egyeztetéseket, ahol nem a hatékonyságról van szó a forráskialakítás témakörében. Reformja öt javaslat mentén haladt:

- széles társadalmi egyeztetéssel végrehajtott forráskoncentráció 3-4 területre

- szigorúbb és fókuszáltabb szerződéses feltételek a Közösség és a tagállamok/régiók között pontosan definiáltan és mérhetően 
eredménykötelezetten, de a tagállamok/régiók számára szabadabb kezet adva a célok megvalósításának módjában

- pontos hatásindikátorok alkalmazása

- humán erőforrásra koncentrált forrásfelhasználás

- az ellenőrzés új rendszerének kialakítása

A német kezdeményezésű, nettó befizető tagállamokat tömörítő „Friends of Better Spending” csoport a minőségi költés feltételeit az alábbi hét ponttal egészítette ki (Ahnborg [2012]):

○ Nagyobb koncentráció a növekedés és foglalkoztatás területére, ill. közvetlen kapcsolat az ország-specifikus ajánlások és a forráskihelyezés között

○ Makrogazdasági-feltételesség erősítése, vagyis egyensúlymechanizmus az Eurozónán belül és kívül egyaránt

○ Közös Stratégiai Keret létrehozása, ami a kohéziós alapok egyszerüsítettebb szabályozását a Vidékfejlesztési és Halászati Alappal is koherensen, gördülékeny felhasználással valósítja meg

- Program-megvalósítás szigorú értékelésével a további forráskihelyezés felfüggesztése lehetségessé váljon, amennyiben az eredmények hiányoznak

○ Tartalék-képzés a jó megvalósítás ösztönzéséért, egyfajta teljesítménytartalék képzése a jól teljesítő tagállamok javára

○ Nemzeti társfinanszírozást szükséges megnövelni annak érdekében, hogy a tagállamok felelősséget érezzenek a felhasználásban

○ Európai Beruházási Bank gyakorlatának kiterjedtebb hasznosítása a projektek meghatározása és elkészítése terén is

A nettó haszonélvező pozíciót betöltő tizenhárom uniós tagállam - közük hazánk is az ún. „Kohézió barátai” csoportját alkotva közös álláspontjukat fejezték ki a következő időszak forrásfelhasználásával kapcsolatban (CMPR [2012]). A hatékonyság előfeltételének tekintik a források egyszerüsített és nagyobb rugalmasságot megengedő tagállami szabályozását, ugyanakkor kinyilvánították, hogy elkötelezettebben lépnek fel a visszaélésekkel szemben. Az államháztartási problémákkal összefüggő forrásvisszatartást és elvonást „,igazságos és kiegyensúlyozott” módon tudják elfogadni, míg a „Better Spending” csoport javaslatával szemben úgy vélik, nem szabad növelni a szegényebb régiók önrészét, 
társfinanszírozási rátáját. (BruxInfo [2012]). Az általános forgalmi adó elszámolhatóságát szintén változatlan formában kívánják megtartani a következő költségvetési időszakban is.

A jogszabályi környezet kialakítására időben utolsóként a Bizottság foglalta össze álláspontját, a minőségi költést elősegítő javaslatok a 2014-2020 többéves pénzügyi keret parlamenti és tanácsi elfogadásával párhuzamosan jelentek meg (Hahn [2013]), és szempontunkból az alábbiak szerint foglalható össze:

1. Valamennyi régióba jusson az alapokból, a társ-finanszírozás mértéke a fejlettségi szinthez kötött legyen.

2. Célzott erőforrások a kulcs-növekedési szektoroknak: a Regionális Fejlesztési Alap 4 kulcsterülete: kutatás-fejlesztés; digitális agenda; KKV-k támogatása; CO2 kibocsátás csökkentése energiahatékonyság és megújuló energiák által, dedikált forrásokkal a régiók fejlettsége alapján. További kiemelt szektor a transz-európai szállítmányozás, valamint a humán erőforrás fejlesztés az életen át tartó tanulással, képzésekkel, szociális felzárkóztatással.

3. Tiszta, átlátható, mérhető célok az elszámoltathatás és eredmények érdekében - teljesítménytartalék bevezetése.

4. Előfeltételek bevezetése a hatékonyság érdekében, pl. ún. „smart specialization”, a közbeszerzési folyamatok javítása vagy környezetvédelmi jogszabályok előzetes harmonizációja, valamint cég-barát reformok alkalmazása.

5. Közös stratégia szükségessége és átfedések elkerülése, ennek érdekében a jelenleg három alapot összefogó Kohéziós szabályozást a Vidékfejlesztési és Halászati Alapra is kiterjesztve alkalmazni.

6. Egyszerübb elszámolási szabályok, fókuszáltabb jelentési kötelezettségek, és „e-kohézió”, vagyis a digitális technológia lehetőségeinek nagyobb fokú alkalmazása.

7. Városi dimenzió erősítése: Regionális Fejlesztési Alapból többletforrás kihelyezése integrált projektek megvalósítására

8. Határ-menti együttműködések megerősítése és makro-regionális stratégiák úgymint a Duna és Balti-tenger - támogatása.

9. Makrogazdasági feltételesség: akár kifizetések felfüggesztése, amennyiben az érintett tagállam nem felel meg a túlzotthiány-eljárás során számára tett 
ajánlásoknak. A korábban csak a Kohéziós Alapra vonatkozó - és 2012-ben elsőként hazánkra alkalmazott - felfüggesztési lehetőség így nagymértékben kibővült.

10. Elismerték a KKV-k megnövekedett igényét a pénzügyi eszközök több és jobb elérhetőségére: a támogatás helyett adott visszatérítendő pénzügyi eszközök a projekt-minőség irányába hatnak a támogatás-függőség oldásával.

3.2.2 A 2014-2020 közötti költségvetést szabályozó hatályos rendeletek hatékonyság korlátozó hozadéka - Szándékok és eredmények

A cím a korábbiakban leírtakkal ellenétes tartalmú sugallata arra utal, hogy - bár a szándék a 2009-es Barca-jelentésben megfogalmazott minőségi költéssel azonos - a hatályos rendeletekbe (EP és ET [2013a,b,c,d,e,f,g]) számos korábbi javaslat épült be, ezáltal kötelezve a tagállamokat a következő hét éves pénzügyi keret felhasználásakor, ugyanakkor sok esetben megkérdőjelezhető a legmegfelelőbb eszköz kiválasztása.

A Friends of Better Spending javaslatának megfelelően a közös rendelkezés kimondja, hogy „,az európai strukturális és beruházási alapok (továbbiakban ESBalapok) müködésének összehangolása érdekében közös rendelkezéseket kell megállapítani” az eddigi három alapon túl az Európai Mezőgazdasági Vidékfejlesztési Alap (EMVA), valamint az Európai Tengerügyi és Halászati Alap (ETHA) vonatkozásában is (EP és ET [2013e] p320.). Ez egyfajta átláthatóságot és koherenciát jelenthet a kialakítandó tagállami szabályozásokban. Szintén a nettó befizetők álláspontjával összhangban, majd bizottsági megerősítésre a közös rendelet 21. bekezdése határozza meg a kifizetések felfüggesztésének lehetőségét az előzetes feltételek elmaradása esetén. Ex-ante feltételeket képeznek az adott területre vonatozó közbeszerzési szabályozások, valamint szektoronkénti stratégiák, amelyek kötelezően meg kell, hogy előzzék és alapozzák az adott ágazatot érintő fejlesztési programokat és projekteket. A közös rendelet harmadik fejezete szabályozza, hogy a különböző szintü célrendszereknek és stratégiáknak úgy kell egymásra épülniük, hogy végül az általános európai uniós EU2020-stratégiába is illeszkedjenek. Ez az ún. „tematikus koncentráció” már a 2009-es Barca-jelentésben megjelenik, és a 
harmadik fejezetben kijelölt módon megalapozza az előzetes feltételrendszer és eredményességi felülvizsgálat gyakorlatát.

A nettó befizetők határozott álláspontját tükrözi a közös rendelkezés végrehajtási jelentések fejezete (EP és ET [2013e] p347.), mely szabályozza a projektek pontos cél-és eredmény-indikátorok követelményét, valamint hogy a konkrét megvalósulást milyen mellérendelt mérőszámok teszik egyértelmüvé (például az út $/ \mathrm{km}$ teljesülésével). A korábbi időszakokban is meglévő gyakorlat azonban kiegészül egy 2017-ben végrehajtott átfogó vizsgálattal, és amennyiben jelentős elmaradást észlelnek, pénzügyi korrekció is történhet Bizottsági részről. A hatékonyság érdekében talán ez a legerősebb szankció, és változás a korábbi periódusokhoz képest, ezt egészíti ki a végül 6 százalékban rögzített „teljesítménytartalék” képzése. A közös rendelet "ESB-alapok eredményességét és a gondos gazdasági irányítást összekapcsoló intézkedések" elnevezésű 23. bekezdése szabályozza a tartalék felhasználását, amelyet az időarányosan 2019-ig jól teljesítő programok és projektek hívhatnak le a 2023-ig még hátra lévő időszakban. Látható az is, hogy a 2007-2013 programozási periódusban csak két tagországnak - Romániának és Szlovákiának engedélyezett $\mathrm{n}+3$-as felhasználási határidő így valamennyi tagország számára elérhetővé vált. Ez utóbbi eredmény a Kohézió barátai érdekcsoport számára az egyik legkedvezőbb fejlemény, mert várhatóan számos országban mutatkozik abszorpciós probléma (Győriné [2014]).

A Bizottság által képviselt városi dimenzió erősítésének reformjavaslata is beépült a jogalkotás folyamán, a közös rendelet 33. bekezdése alapján (EP és ET [2013e] p.325) a tagállam egy város- vagy területfejlesztési stratégia mentén integrált beruházásokat hajthat végre. A komplex megközelítés akár az összevonásba újonnan került Vidékfejlesztési és Halászati Alap operatív programjainak együttes kezelését is jelentheti. Ez jelentős rugalmasságot hozhat a korábbi, egy program-egy alap és prioritás-szintü megközelítéssel ellentétben.

A Kohézió barátai érdekcsoport által képviselt álláspontok több pontban is megjelentek a brüsszeli szabályozásban. Így az adminisztratív terhek csökkentése nemcsak uniós, de tagállami szinten is elvárt a Kedvezményezettek irányába (EP és ET [2013e] p.321), valamint ismét elérték a vissza nem térítendő ÁFA elszámolhatóságát is, mellyel ténylegesen kihelyezhető forrásokat csökkentettek és 
tagállami költségvetést növeltek azon fejlesztésekböl, ahol a projektgazda az általános forgalmi adót is elszámolhatja a beruházás keretében. Az önkormányzati és civil szervezetek beruházásai, és programjai, az alanyi mentességgel rendelkező vállalkozói kör, valamint a vállalkozók nem alaptevékenységébe tartozó fejlesztésekre elnyert támogatások ÁFA-tartalma ezért képezheti a támogatás részét. A korábbi 75 százalékos társfinanszírozási bizottsági javaslattal ellentétben az uniós átlag 75 százaléka alatt lévő régiók esetében a közösségi társfinanszírozás mértéke továbbra is 85 százalékos maradt (BruxInfo [2013]).

Nominálisan rögzítették az Európai Szociális Alapra (ESZA) minimálisan fordítandó százalékos arányt, mely összhangban van Andor László, az Európai Bizottság akkori szociális- és foglalkoztatáspolitikai ügyekért felelős biztosa 2011-es javaslatával is, aki kiállt az alap által finanszírozott programok szükségessége és az alap mind nagyobb arányú felhasználása mellett (BruxInfo [2011]). Így az „ESZA részaránya a Strukturális Alapok és a Kohéziós Alap uniós szinten egyesített összes forrásának százalékában - az Európai Hálózatfinanszírozási Eszköz keretében a közlekedési infrastruktúra támogatására a Kohéziós Alapból nyújtott támogatást és a leginkább rászorulók számára a strukturális alapokból nyújtott támogatást kivéve - a tagállamokban legalább 23,1 \% ” (EP és ET [2013e] p.331).

A két évet meghaladó egyeztetési folyamatok folytonos témája és legvitatottabb pontja az ún. makrogazdasági feltételesség kiterjesztése volt. Korábban kizárólag a Kohéziós Alapot érintő - és első esetben Magyarországgal szemben érvényesített túlzottdeficit-eljárás pénzügyi felfüggesztése a közös rendelet 87 . bekezdése értelmében „valós gazdasági hatás elérése céljából és szélesebb gazdasági összefüggések " érdekében pénzügyi zárolást eredményezhet mind az öt alap tekintetében (EP és ET [2013e] p.331). A nettó haszonélvező tagállamokkal szemben képviselt bizottsági érvek azt is felszínre hozták, miszerint a gazdasági válság arra is rávilágított, hogy a makrogazdasági problémákkal küzdő tagállamok nem tudják az önerőt is feltételező közösségi forrásokat teljesen felhasználni. A parlamenti jóváhagyást végül néhány kompromisszum, enyhítés eredményezte; potenciális csökkentési körülmény, ha az elmarasztalásra ítélt tagországban a felfüggesztés előtti 
évben a munkanélküliség az európai uniós átlag felett volt, vagy a felfüggesztést megelőző két évben recesszió sújtotta a tagállamot.

Összegzésként elmondhatjuk, hogy a korábbi javaslatok szinte kivétel nélkül megjelentek a végleges jogszabály-csomagban, ugyanakkor a tagállami alkuk során sok esetben „erejüket veszítették”. Adódtak továbbá fókusz-problémák és a korábbi gyakorlatokon, vagy tagállami finanszírozói attitüdökön - a költségvetés haszonélvezői vagy befizetői megközelítésen - nehezen emelkedtek felül az országok az uniós szintü érdekek elérése érdekében, vagy épp fordított eredménye lett az eredeti szándéknak. Kiemelendő továbbá, hogy a hosszas alkudozás a jogszabályi keretrendszer véglegesítésében is nagy késedelmet hozott, eddigi legkésőbbi hatályba lépést eredményezve. Hazánk esetében az Unió Bizottsága 2014. augusztus 29-én fogadta el a Partnerségi Megállapodás szövegét, melyet 2014. szeptember 11-én írt alá Budapesten Magyarország miniszterelnöke és az Európai Unió Bizottságának elnöke. Az operatív programokat 2014. év végével nyújtotta be hazánk, és 2015. februárban hagyta jóvá az operatív programok döntő többségét. A fent bemutatott hatékonyság-fókuszú jogszabályi változások a tagországok intézményi és

programozási feladatainál erős szük keresztmetszeteket adtak, melyet a magyarországi intézményi és a 2014-2020-as programozási feladatok bemutatásával teszek kézzelfoghatóvá.

\section{FEJEZET: MAGYAR INTÉZMÉNYRENDSZERI SAJÁTOSSÁGOK, PROBLÉMÁK}

\subsection{Hazai intézményi változások - hátraarc egy évtized alatt}

Magyarországon „A területfejlesztésről és a területrendezésről” szóló 1996. évi XXI. törvény (továbbiakban Tftv.) a hangsúlyt a tervezés fontosságára helyezte, meghatározta a területfejlesztés intézményrendszerét és eszközeinek körét. A tervezés a területfejlesztési koncepcióra épült, mely meghatározta a térség átfogó, 
távlati fejlesztését. Ez alapján került kidolgozásra a területfejlesztési stratégia, melyböl a regionális területfejlesztési programok, mint középtávú cselekvési tervek építkeztek (Pálné [2003]). A törvény biztosította továbbá a keretet az öntanuló regionális fejlesztés elindításához is. A regionális szint kialakítása egyértelműen az Unió ösztönzésére történt, elsősorban az uniós források felhasználásával összhangban (Phare, majd strukturális alapok). Ugyanakkor kijelenthető, hogy a nemzeti, illetve a megyei szinttel való párhuzamosságok megmaradtak, a felelősségek és kompetenciák közötti egyértelmü elhatárolás is csak a pénzeszközök végrehajtásával kapcsolatban történt meg (Döbrönte-Vida [2011]). Az Államreform Operatív Program keretében végzett utólagos hatásvizsgálat megállapítja, hogy Magyarország „területfejlesztési intézményrendszerét 2012. január 1-jét megelőzően a területi szintek magas száma (kistérség, megye, régió, kiemelt térség, országos szint), ebből adódóan az indokolatlan párhuzamosságok és az alacsony hatékonyságú müködés jellemezte, melyet tovább gyengített, hogy a hazai és az uniós forrásokat kezelő intézmények és a támogatások felhasználásának szabályozása terén szintén párhuzamos rendszer épült ki.” (Magyarország Kormánya [2012] p.16). A területfejlesztés intézményrendszerében 2012. január 1-jén bekövetkezett változások alapján a területfejlesztési feladatok megyei önkormányzatra telepítésével a korábbi kistérségi és regionális szintü területfejlesztési tanácsok megszüntetésre kerültek.

A fenti változásokból eredő stabilitáshiány miatt az egyes szereplők regionális/megyei/kistérségi területfejlesztési szervezetek, az operatív programok felhasználásának bonyolításában dolgozó közreműködő szerveztek - munkája során felhalmozódó szaktudás, tapasztalat és partnerségek ismerete elvész. Elvész továbbá az az idő, ami az egyes szereplők bekapcsolódását tenné lehetővé a területfejlesztés tervezésébe. Ez megjelent a 2007-2013-as programozási időszak kezdetén is, amikor a regionális operatív programok kialakításakor a LAU I-es szintnek megfelelő kistérségi szintet közvetlenül a Regionális Fejlesztési Ügynökségek alá rendelték, a megyei szint kihagyásával. A megyei területfejlesztési szereplőknél felhalmozódó, korábbi hazai költségvetési forrású területfejlesztési támogatások kihelyezésében és bonyolításában szerzett ismeret és humánerőforrás kapacitás „parlagon hagyása” súlyos hiányossága ennek a tervezési periódusnak. Most azonban fennáll a veszélye, hogy a folyamat a következő hét éves programozásnál megismétlődik, csak visszafelé. A Tftv. 2012-es módosítása a korábbi öt területi szint helyett alapvetően két területi szintet határozott meg (megyei és országos), visszaállította az uniós 
csatlakozás előtti térségbontást. A megyei szintek újbóli megerősítésével, a kistérségek megszüntetésével és a régiók súlytalanná/névlegessé tételével, majd megszüntetésével megtörténhet, hogy az elmúlt hét év tapasztalatai késedelmesen vagy csorbultan csatornázódhatnak be a következő operatív programok célrendszerének, illetve megvalósítási módszereinek kialakításához.

Szintén ezt a problémát veti fel a felhasználás koordinációját és stratégiai kérdéseit megvalósító irányító hatóságok delegálása, mely 2004-2006-ban az ágazatokhoz rendelten müködött, ezt követte egy központi szervezet (Nemzeti Fejlesztési Ügynökség) létrehozása a 2007-2013-as időszakra, majd a 2014-2020 közötti forrásoknál ismételten a szakminisztériumokhoz kötött irányítás jelenik meg, egy területfejlesztési operatív programmal, valamint ágazati programokkal. A változás valós igényre reagált, Perger (2010) olyan átfogó stratégiai menedzsmentet sürgetett, amely miközben erős koordinációs és ellenőrzési mechanizmusokat működtet, mind a tervezésben, mind a végrehajtásban nagyobb teret ad az ágazati és területi szereplőknek. Míg a szakminisztériumi szerep erősödött, addig a területi szint csorbult a LAU I-s szintnek megfelelő, most már járási besorolású közigazgatási méret részvételének csökkentésével. Kijelenthető, hogy a közel másfél évtizede zajló, folyamatos és szélsőséges változások nem segítik elő a véghajrában lévő 20072013-as elszámolási, valamint a 2014-2020-as időszak tervezési előkészületeit. A belső, olykor „hátra-arc” megoldásban kialakuló intézményi átszervezések csökkentették programszinten is a hatékonyságot a 2014-2020-as időszak tervezésének időbeni előrehaladásában, a korábbi tapasztalatok és tanulságok beépítésében, a területi igények visszacsatornázásában, a szakemberek erős fluktuációjában. A projektszintű hatékonysági problémáknak szintén volt egy időtényezője, vagyis a projektmegvalósítások során felmerülő kérdések, támogatási szerződések módosításának szándéka, elszámolások feldolgozásának csúszásából eredő cash-flow problémák velejárói voltak az intézményátszervezésnek. A Hétfa Kutatóintézet Területi kohéziós jelentése kiegészítette ezt az alábbi két jelenséggel is (Balás [2013] p.199), melyek szintén a hatékonysággal ellentétes irányba mutatnak:

- A központi és a helyi szereplők közötti kölcsönös bizalomhiány, együttmüködési kultúra hiánya, amelyet a lehatárolásokkal szabdalt fejlesztéspolitika sem helyi szinten nem tudott megoldani, sem központi szinten nem sikerült a kiírásokat úgy 
összehangolni, hogy a helyi szinten kialakuló együttmüködések költségét jelentősen meg ne növeljék;

- A fejlesztési szereplők közötti, minden fejlesztéstípusnál inkább rivalizálásra ösztönző pályázati versenyben a források megszerzése önmagában elegendő sikertényezővé vált, és nem a fejlesztések eredményei váltak a siker mérőszámává;

A közép-európai tagállamok közül a hazaival ellentétes példát mutat Lengyelország, mely nem csak statisztikai, hanem tényleges közigazgatási reformot hajtott végre a területfejlesztés átalakításában, melynek hatására a regionális politika önálló ágazati politikává tudott válni. Az intézményrendszer az ágazati irányítás rendszerébe integrálódik, mégis decentralizált formában müködik a decentralizált operatív programok irányításában (Mezei - Schmidt [2013]). Lengyelország az egyetlen a kelet-közép-európai országok közül, ahol a közigazgatási reform és a területfejlesztési intézményrendszer építése párhuzamosan és koherens módon zajlott. Itt nem találjuk a Közép-Kelet-Európában megszokott területfejlesztési tanácsokat, máig nem született területfejlesztési törvény, ahogyan nem alakult az alapok fogadására kiépített önálló intézmény sem. Helyette a tényleges decentralizáció eredményeként a régiók valódi döntési jogokkal, fejlesztési forrásokkal, alulról építkező fejlesztési programokkal, valamint az azok végrehajtását garantáló tervszerződésekkel rendelkeznek (Mezei - Schmidt [2013] p.123). Az újonnan alakult vajdaságok választott önkormányzatai - szemben a hazai volt regionális fejlesztési tanácsokkal - nem csupán a támogatáspolitika kijelölt, bizonyos minimális források elosztására feljogosított szereplői, hanem a tényleges decentralizáció révén a helyi társadalom- és gazdaságfejlesztés szereplöi is egyben. Lengyelország jó példája annak, hogyan lehet a területfejlesztés feladatát a felülröl vezérelt módtól az önkormányzati szektor felé, az alulról építkező mód felé terelni.

\subsection{Intézményrendszeri összetettség}

A fenti kronológiák jól szemléltetik azt a bizottsági „rugalmasságot”, mely a megosztott irányítás jegyében az intézményrendszer kialakításának és a megvalósítás folyamatának szabályozását az egyes tagállamokra hagyja (Berky [2013] p.253-256). Jóllehet a programozásban szigorú számonkérés dominál, addig az azt megvalósító 
intézményrendszerben páratlan szabadságot enged (bár a Bizottság auditálási eljárása nem mellőzhető). Megítélésem szerint ez a szélsőség nem kedvez a koherens és kiegyensúlyozott, az esetleges politikai környezeti változások tompításának, melynek egyik szemléletes megnyilvánulása a hazai területfejlesztési intézményi környezet egy évtizeden belüli teljes átalakítása, valamint az a kevésbé látványos, de a megvalósításban számottevően érzékelhető humán-erőforrás fluktuáció, mely a megvalósítás számos pontján akadályként jelentkezett.

A 2007-2013-as programozási periódus hazai intézményi struktúráját szemlélteti a következő két ábra (2. ábra és 3. ábra). A közigazgatási struktúra és annak de facto integráns részét képező forrás-felhasználási intézményrendszeri struktúra kettősége jellemzi a magyar forrásfelhasználást, és a szinte átláthatatlan bonyolultság jól látható a következő két ábrán.

2.ábra: Magyarország támogatás-felhasználási intézményrendszere a 2007-2013-as programozási periódusban

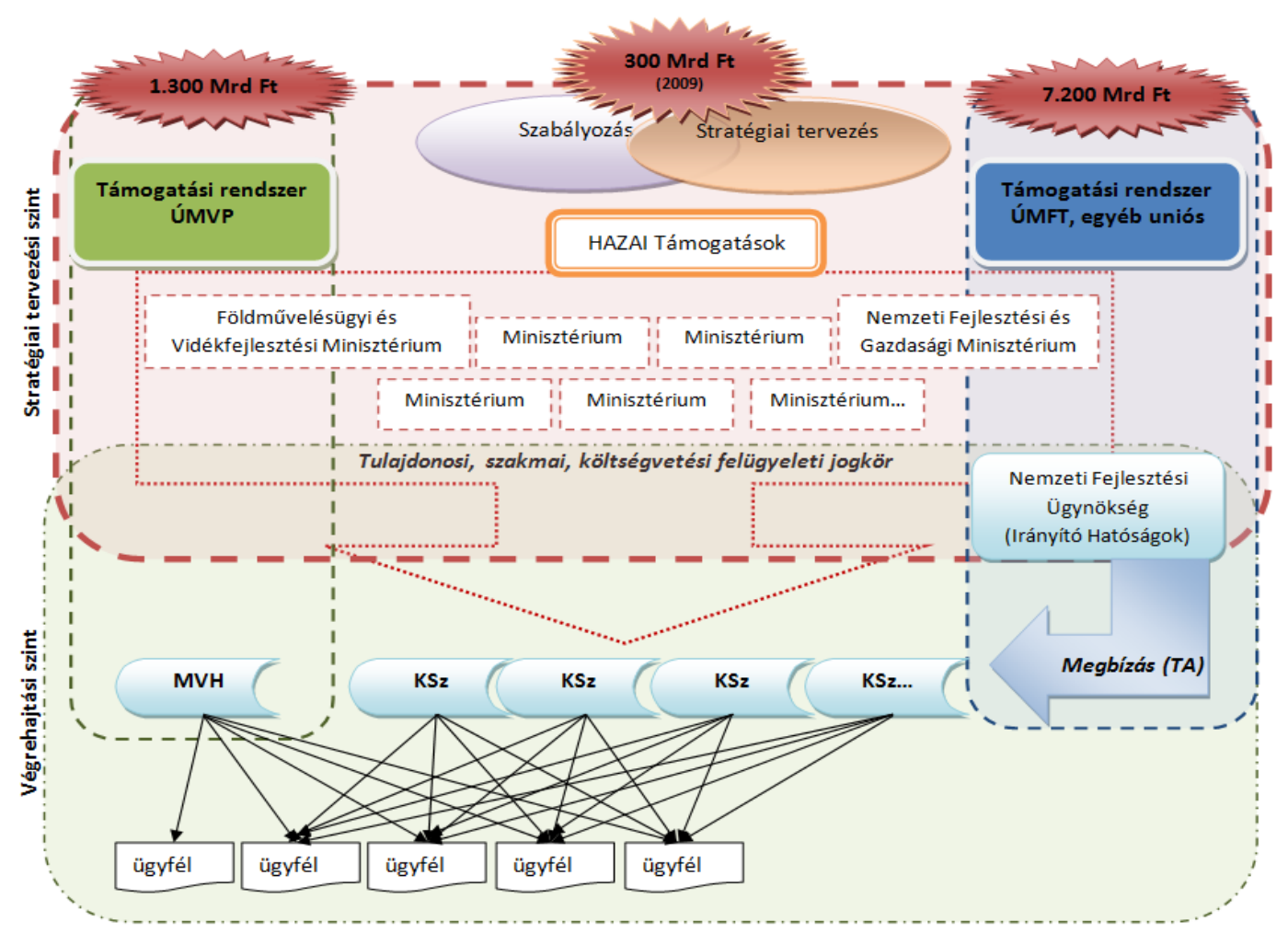

Forrás: Nemzeti Fejlesztési Ügynökség: Fejlesztési Programok 2007-2010; http://palyazat.gov.hu/uj_magyarorszag_fejlesztesi_terv_2; Lekérdezve: 2015. augusztus 28. és Szücs András: „Magyarország uniós programjai az 
intézményrendszer oldaláról” címü elöadása, Nemzetgazdasági Minisztérium, 2015.05.07.

3.ábra: A támogatás-felhasználás kapcsolati hálója Magyarországon a 2007-2013-as fejlesztési időszakban

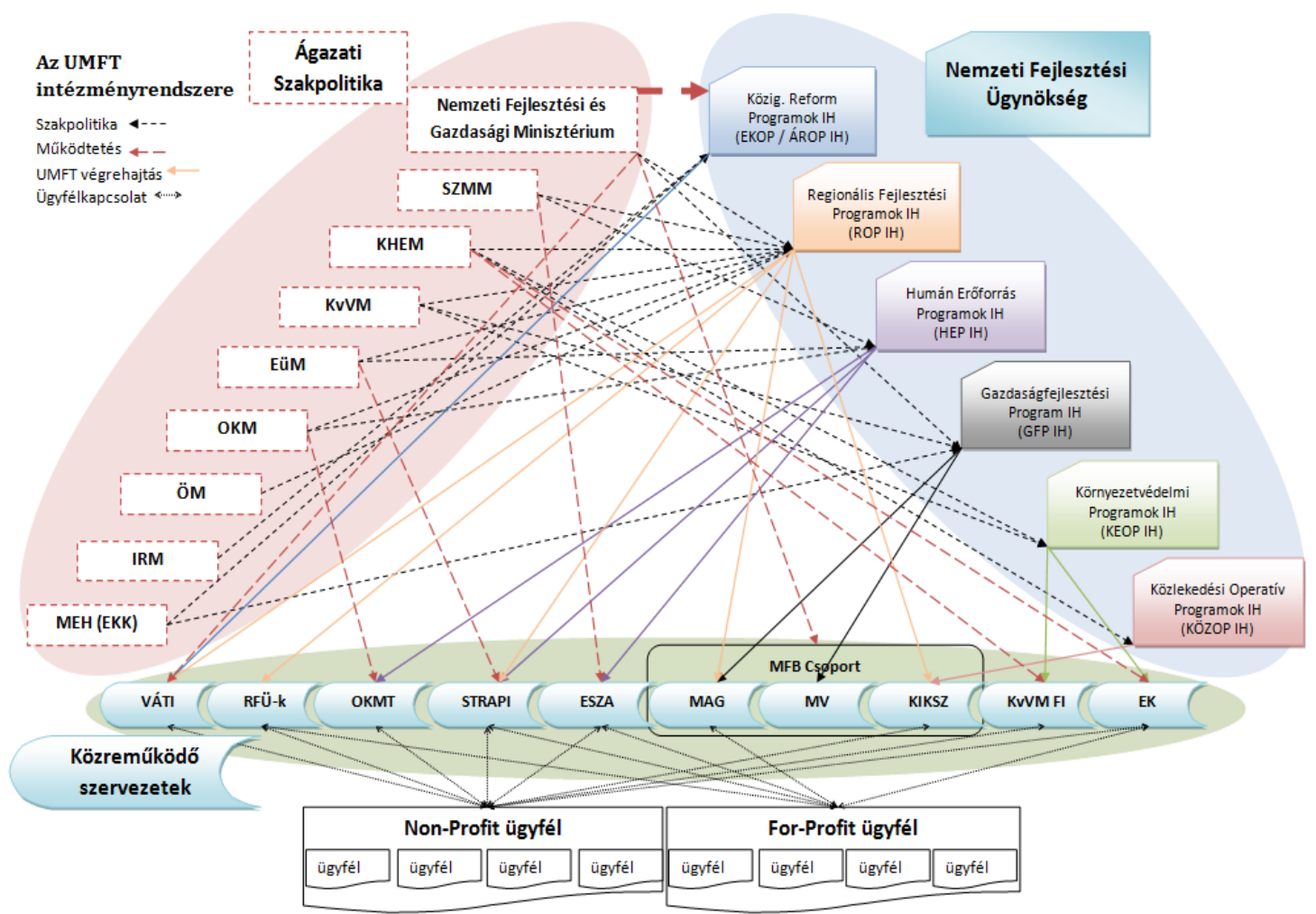

Forrás: Nemzeti Fejlesztési Ügynökség: Fejlesztési Programok 2007-2010; http://palyazat.gov.hu/uj_magyarorszag_fejlesztesi_terv_2; Lekérdezve: 2015. augusztus 28. és Szücs András: „Magyarország uniós programjai az intézményrendszer oldaláról" című előadása, Nemzetgazdasági Minisztérium, 2015.05.07.

Mindkét ábra a fejlesztéspolitikai környezet kódolt konfliktusait láttatja, valamint azt a különösen a támogatott/kedveszményezett szemszögéböl érzékelt zavart, mely a hatékonyság szempontjából két tényezőt sért programszinten: az átláthatóságot, és az időbeni reakciók lehetőségét. 
4.3 Az Európai Bizottság új programozási elvárásai a tagállami programalkotás folyamatában - magyar vonatkozások az eredeti minőségi szándék torzulásának tükrében

A korábbiakban bemutatásra került, hogy a gazdasági válsággal is terhelt 2007-2013as költségvetési periódus tapasztalatai alapján mind tartalmi, mind abszorpciós teljesítést tekintve egyaránt szigorúbb szabályozási rendszert alakított ki az Európai Unió Bizottsága a 2014-2020-as fejlesztéspolitikai forráskeret tekintetében egy 25 hónapos tagállami érdekegyeztetetési folyamat eredményeként. A felülröl vezérelt tervezés erőteljesebb tematikus fókuszokat fogalmazott meg az EU2020 stratégia prioritásaival összhangban, melyeket az alábbiak szerint foglalhatunk össze:

- Intelligens növekedés: az oktatási, a kutatási és az innovációs beruházások hatékonyabbak, ezért kiemelt forrásráfordítást igényelnek.

- Fenntartható növekedés: kulcseleme az alacsony szén-dioxidkibocsátású gazdaságra való átállás.

- Inkluzív növekedés: nagy hangsúlyt fektet a munkahelyteremtésre és a szegénység csökkentésére.

A hatékonyabb felhasználás igénye - melyet a 2009-ben kiadott ún. Barcajelentés a minőségi költés fogalmával újradefiniált - mind a nettó befizető tagállamok egyre élesedő elvárásait tükrözte, és abból a tényből is származott, hogy a teljes kohéziós fejlesztéspolitika során most szembesülhettünk először a korábbiaktól kisebb forráskeret létrehozásával '(Barca [2009]). A csökkentésnek nem annyira mértéke, mint maga a tendencia megfordulása beszédes egy bővülö/bővülés lehetőségét nem kizáró közösségben.

Az erősebb témakontúrok ún. tematikus célkitüzésekben rajzolódtak ki, és az alábbi tizenegy pontban foglalta össze a Bizottság a tagállamok kötelezettségét, melyet érvényesíteniük szükséges a teljes programozási időszak folyamán:

1. Kutatásfejlesztés és innováció $(\mathrm{K}+\mathrm{F}+\mathrm{I})$

2. Információs és kommunikációs technológiák (IKT)

3. Kis- és középvállalatok (KKV-k) versenyképessége 
4. Haladás az alacsony széndioxid-kibocsátású gazdasági modell felé

5. Klímaváltozással kapcsolatos átállás, továbbá kockázatmegelőzés és -kezelés

6. Környezetvédelem és eröforrás-hatékonyság

7. Fenntartható közlekedés/szállítás, továbbá megoldások a föbb hálózati infrastruktúrák szük keresztmetszeteire

8. Foglalkoztatás fejlesztése, és a munkaerő mobilitásának támogatása

9. A szegénység elleni küzdelem, és társadalmi felzárkóztatás

10. Oktatás, készségfejlesztés és élethosszig tartó tanulás

11. Intézményi képességek és a hatékony közszolgálat fejlesztése

A fenti tematikus célkitűzésekhez összetett forrásallokációs arányosítás is társul, ugyanakkor ennek kötöttsége és bonyolultsága akkor válik kézzel foghatóvá, amikor egy tagállam hét éves felhasználási dokumentumában, a partnerségi megállapodásban és az azt alkotó operatív programjaiban számszerüen látjuk.

Fontos adaléka a programozás folyamatának továbbá, hogy a hosszas alkudozás a jogszabályi keretrendszer véglegesítésében is nagy késedelmet hozott, szintén a fejlesztéspolitika történetében az eddigi legkésőbbi hatályba lépést eredményezve. A szabályozó rendeletben újdonságként (és eredetileg a könnyítés szándékával megalkotott módosítás) megjelenő $\mathrm{n}+3$-as felhasználási határidő ugyan egy évvel meghosszabbítja a felhasználás határidejét, de a késedelmes jogszabályalkotásból származó csúszással de facto nem történik változás a felhasználásra rendelkezésre álló időtartam tekintetében. Jóllehet a 2007-2013 programozási periódusban csak két tagországnak - Romániának és Szlovákiának - engedélyezett $n+3$-as felhasználási határidő így valamennyi tagország számára elérhetővé vált, és indokoltsága számos tagország abszorpciós mutatói ismeretében valós igény lenne, de a tagállami programalkotásnak elengedhetetlen előfeltétele a hatályos uniós jogszabályok megléte, mely eddig sosem „nyúlt be” ilyen mértékig az érintett periódus felhasználási idejébe (Győriné [2015]). Hazánk esetében - ahogyan az már korábban említésre került - az Unió Bizottsága 2014. augusztusában fogadta el a Partnerségi Megállapodás szövegét, melyet 2014. szeptemberében írtak alá Budapesten. Az operatív programokat 2014. év végével nyújtottuk be, és 2015. februárban hagyta jóvá Brüsszel az operatív programok döntő többségét (a korábban külön 
eljárásrendben kezelt és külön alapokat jelentő vidékfejlesztési és halgazdálkodási program, valamint a közigazgatást és közszolgáltatást érintő programok bizottsági jóváhagyása vált el időben a többi programtól).

A fent bemutatott - eredetileg - hatékonyság-fókuszú jogszabályi változások a tagországok intézményi és programozási feladatainál nemcsak késedelmes, de erős szük keresztmetszeteket adtak, melyet a magyarországi intézményi és a 2014-2020as programozási feladatok bemutatásával teszek kézzelfoghatóvá.

\subsection{Az új hét éves forráskeret hazai felhasználásának programterve}

Az uniós szintű tematikus célkitűzésekhez társított tagállami vállalások összevetését foglalja össze a következő két ábra (4. és 5. ábra). Az ún. EU 2020 célkitüzések, vagyis elvárások (4. ábra) magyarországi teljesítésének számszerü vállalásait, vagyis kötelezettségeit (5. ábra) mutatja be e két

A 20-64 évesek legalább $75 \%$-ának munkahellyel kell rendelkeznie

Az EU GDP-jének $3 \%$-át a K+F-re kell fordítani

Az üvegház hatású gázok kibocsátásának $20 \%$-os csökkentése

Energiahatékonyság 20\%-os növelése

Megújuló energia részarányának 20\%-os növelése

Az iskolából kimaradók aránya maximum $10 \%$

A felsőfokú végzettségúek aránya minimum $40 \%$

A szegénység kockázatának kitett lakosok számát 20 millióval kell

4.ábra: EU 2020 CÉLKITÜZÉSEK ábra.

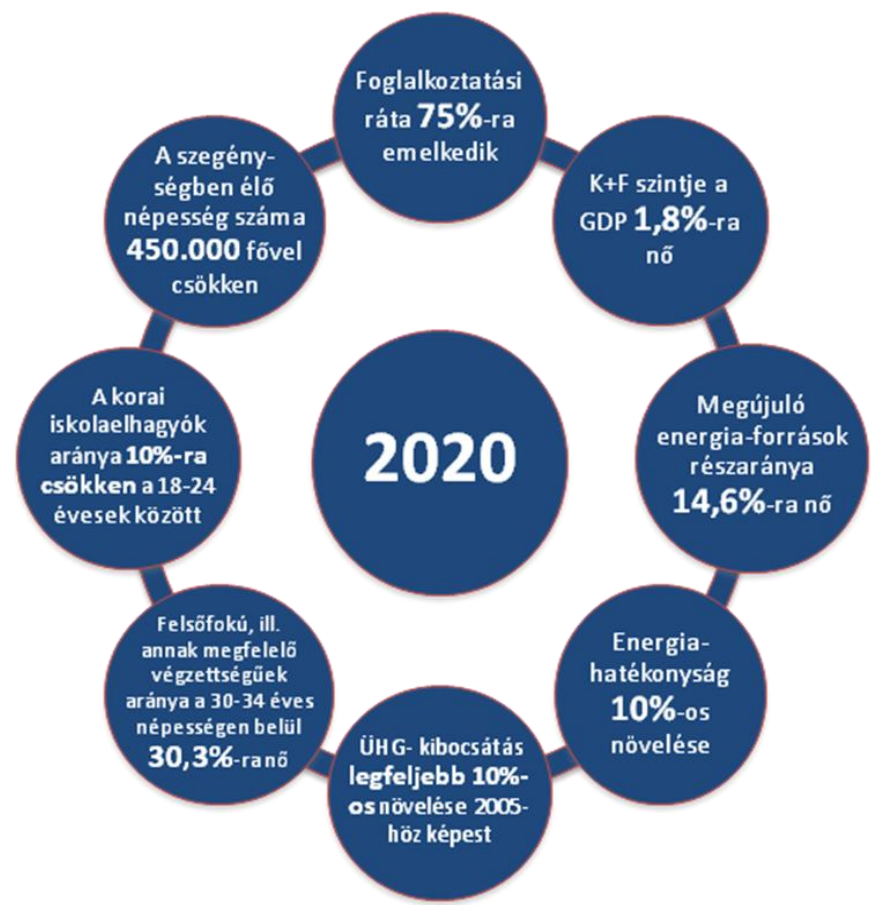

5.ábra: Magyarország vállalásai a Partnerségi Megállapodás szerint 
Forrás: EP és ET [2013 a,b,c,d,e,f,g] és Magyarország Partnerségi Megállapodása a 2014-2020-as fejlesztési időszakra; http://palyazat.gov.hu/szechenyi 2020 Lekérdezve: 2015. 08.28.

Jól látható, hogy az oktatási, foglalkoztatási és szociális mutatókban szinte teljes igazodást vállalt Magyarország, míg az energiahatékonyság és kutatás-fejlesztés területén óvatosabb - és reálisabb - számok jelenítik meg a hazai kötelezettségeket. A programozási folyamat és megvalósítás során a fenti sarokszámok programokon átívelő teljesülését kell biztosítani annak érdekében, hogy a félidei eredményességi felülvizsgálat és a 2019-es tartalék-felhasználás ne eredményezzen forrásvesztést. Ennek további megkötését mutatja a 2. számú táblázat, mely összefoglalja a tematikus koncentráció pontos megoszlási arányait az alapok (Európai Szociális Alap - ESZA és Európai Regionális Fejlesztési Alap - ERFA) tekintetében, valamint a tagállamon belüli eltérő fejlettségü régiók vonatkozásában, végül össz-program szinten is.

1. táblázat: A magyarországi forrásallokációs programalkotási arányok a 20142020-as programozási periódusban

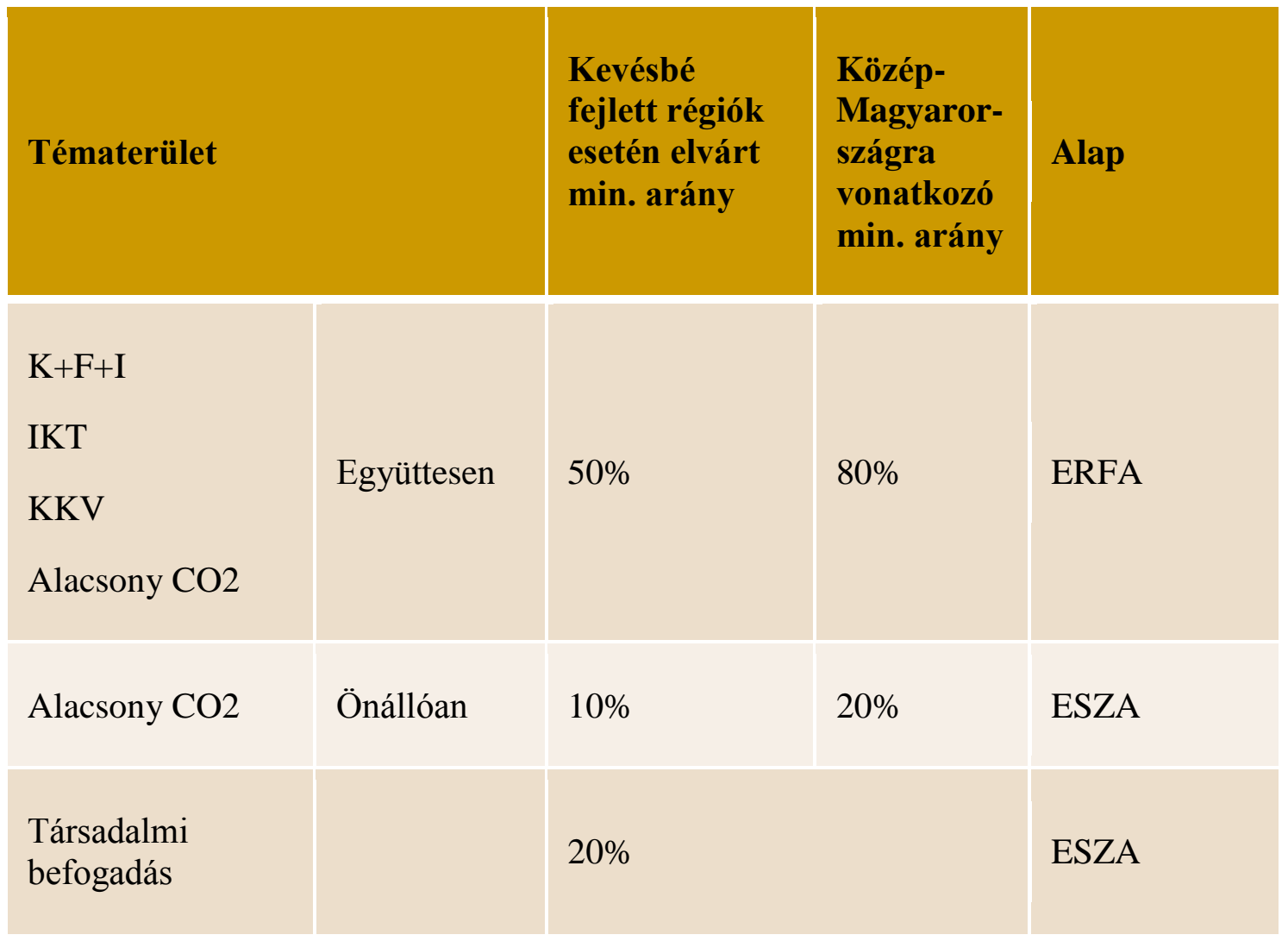


Foglalkoztatás

Társ. befogadás

és szegénység

$20-25 \%$

$45-50 \%$

$\mathrm{ERFA+ESZA}$

Oktatás

Városrehabilitáció

$5 \%$

ERFA

Forrás: ET [2013]: A TANÁCS 1311/2013/EU, EURATOM RENDELETE (2013. december 2.) a 2014-2020-as időszakra vonatkozó többéves pénzügyi keretről.

A 2. számú táblázatban látható aránypárok, és az ún. EU-2020 célkitüzések vállalásai (4. és 5. ábra), valamint az egyes operatív programok önálló szabályozás-rendszere egy közel négy-dimenziós mátrix-rendszerü tervezési kihívás elé állította a tagállamokat, melyek egyszerre néztek szembe a 2007-2013-as programozási periódus $\mathrm{n}+1$. évben (2014-ben) annak abszorpciós, és tartalmi vállalásainak teljesítésével, valamint az új időszak késedelmes, még koncentráltabb, kötött, és sok esetben nem véglegesedett elöírásaival a programalkotás idején. E nehezített körülmények között hazánk a regionális tervezés szintjeinek teljes átalakításával az alulról történő igény-meghatározáskor valamennyi megyének lehetőséget adott az ismét megerősített fejlesztési szinten területfejlesztési programalkotásra. A 2014. és 2023. között megvalósítani kívánt operatív programokat annak tükrében részletezem, hogyan találkozott a két alapelv - adekvát szubszidiaritás és legitim partnerség teljesülésének hiányával a térségfejlesztés új legalsó szintjén, a megyéknél.

4.4.1 A hazai operatív programok és az új területfejlesztési alapegység egymásra épülésének kérdései

Az Európai Parlament és Tanács az új fejlesztéspolitikai szabályozási keretrendszerről (EP és ET [2013a,b,c,d,e,f,g]) minden eddigi programozási időszakkal összehasonlítva legkésőbb, a fejlesztési periódus időbeni vonatkozása előtt alig két héttel, 2013. december 17-i dátummal döntött. Ez a rendeletalkotási 
késedelem is hozzájárult a tagállamok - köztük hazánk - programalkotási dokumentumainak elhúzódó készítéséhez, a magyar operatív programok döntő hányada 2015. márciusában vált véglegessé. A megyei területfejlesztési folyamat a 2012-től indult új decentralizált szintre delegált tevékenységekkel így nevezhető párhuzamosnak a 2014-2020-ra vonatkozó uniós szabályozási keretek kialakításának időszakával, de míg a megyei programalkotások döntő hányada 2013-ban zajlott, az időben utolsóként készült és jelen vizsgálatban hivatkozott - Jász-Nagykun-Szolnok Megyei Területfejlesztési Program - dokumentum Magyarország Partnerségi Megállapodásának Európai Bizottság általi jóváhagyásával esett azonos hónapra, 2014. augusztusra. Így jóllehet az operatív programok tervezési alapját képezhetik a megyei stratégiák, de a tényleges tartalomfejlesztés - az operatív programok tartalmának végső kialakítása - a fenti megyei területfejlesztési dokumentumok véglegesítését követően történt. A megyei területfejlesztési dokumentumok a partnerség elvének jegyében a társadalmasítás keretében szolgáltak inputként az ágazati operatív programok és a TOP esetében is. A helyzetfeltárásra épülő koncepció és ennek alapjaira készült megyei Területfejlesztési Programra az jellemző, hogy valamennyi ágazati program fejlesztéseit érinti, de eltérő súllyal. A program prioritásait alkotó témák jóllehet ágazati megközelítést adnak, nem azonosíthatóak a 2014-2020-as fejlesztési időszakra jóváhagyott operatív programok lehatárolásaival. Ez nem is volt teljes mértékig elvárható, hiszen időben megelőzte azokat, ugyanakkor jelentős hangsúlyeltolódások is láthatóak például a turisztika, a közútfejlesztés és más települési alap-infrastruktúra fejlesztési igény irányába a megyei dokumentumokban. Az első két téma azért is érzékeny, mert a brüsszeli jogszabályalkotás és tagállami tárgyalások jelentős restrikciót okoztak mindkettő forrásallokációjában. A helyzetfeltárást, koncepciókészítést és az ezekre épülő programalkotást kísérő partnerségi folyamatban megszólított és elért szereplők elemzése nem mellőzhető az értékelés komplexitásának igénye esetén. Jóllehet a mind szélesebb körü bevonás szándéka megjelent, ugyanakkor a mérvadó inputnak tekinthető térségi visszajelzések kizárólag az önkormányzati szereplök részéről valósultak meg. Ennek okai visszavezethetőek az intézményváltozások okozta átláthatatlan tervezési helyzetre, vagyis a megyék eddigi súlytalan szerepére a 2004től indult fejlesztési támogatások lehívásában. Kiemelkedően gyenge a vállalkozói és civil szereplők igénymegjelenítése. További következmény azonosítható szintén az elmúlt tíz év uniós pályázati megoldások „válaszreakciójaként”, vagyis a nyílt, 
országosan kiírt, versenyszempontú pályázatkezelési rendszer gyakorlatának köszönhetően. A vállalkozások érdemi megszólítása és elérése nem következett be, különösen a ,soft” lehetőségeket és a $\mathrm{K}+\mathrm{F}$ tartalmakat illetően, valamint a foglalkoztatási megközelítésű, de szociális eredetü vonatkozások tekintetében.

Nem jelent meg továbbá a számottevő ágazati inputot jelentő, de megyei igényeket, jellemzőket azonosító térségi szereplők - jellemzően állami intézményi keretek között müködő - térségi szereplők integrálása, mint pl. a munkaügyi központok, szociális és egészségügyi ellátórendszerek eredményformáló véleménye sem. Ez szintén visszavezethető arra a tényre, hogy a területfejlesztési rendszer korábbi regionális megközelítése megszünt, és a most már szaktárcákhoz rendelt ágazati müködés dominanciája még erősebb, és a nevesített szereplők fejlesztési „referálása” az adott minisztériumhoz történik.

A megszólítás nehézségén túl további hátrányt jelentett, hogy a szereplök számára igazodási alapot a 2007-2013-as programozási időszak regionális tartalma jelentett, az új lehetőségekkel, esetleg egyfajta menü-rendszer megközelítésben sem találkoztak. Ez már az önkormányzati szektor esetében is megállapítható. A komplexitás a funkcióbővítő és szociális város-rehabilitációs szintjéig/módszertanáig megtörtént, ugyanakkor a téma szempontjából egyik meghatározó példa a CLLD tervezés kísérleti alkalmazása, valamint a szélesebb tartalmi igény hiánya az TOP 5. prioritás tartalmában is jól nyomon követhető. Utóbbira példa a települési szinten készítendő foglalkoztatási paktumok, melyek módszertanát az első magyarországi programozási időszakban alkalmazták, most a TOP-ban átfogó fejlesztési szándékként jelenítenek meg, ugyanakkor ez eddig hazánkban nem általánosan, hanem kísérleti jelleggel jelent meg egy évtizede és a települések 10\%-át érintette. Ennek integrált és programszintü kezelése szükséges lesz, azonban a megyei program-alkotásban ez a megközelítés - jóllehet a legnagyobb részvételi arányt felmutató önkormányzati szférát érintő lehetőség - nem jelent meg. Összegzésként elmondható, hogy az intézményi és tartalmi igazodási nehézségek következményeként a szubszidiaritás elvének adekvát alkalmazási szándéka a tervezés eddigi szakaszában nem érvényesült olyan mértékben, mely a szaktárca szándéka szerint szükséges és elégséges lett volna, így a megyei fejlesztési dokumentumok tartalma is erősen korlátozott volt a mélyebb és konkrétabb specifikus tervezéshez. 
4.4.2 Magyarország operatív programjainak bemutatása egy megyei területfejlesztési stratégia tükrében

A Partnerségi Megállapodás tíz operatív programot rögzített, Magyarország 2023-ig 12000 milliárd forint fejlesztési forrást használhat fel az Európai Unió és a hazai költségvetés támogatásával, melynek forrásarányait a következő (6. ábra) mutatja be:

6.ábra: Magyarország egyes operatív programjainak forrásarányos megoszlása

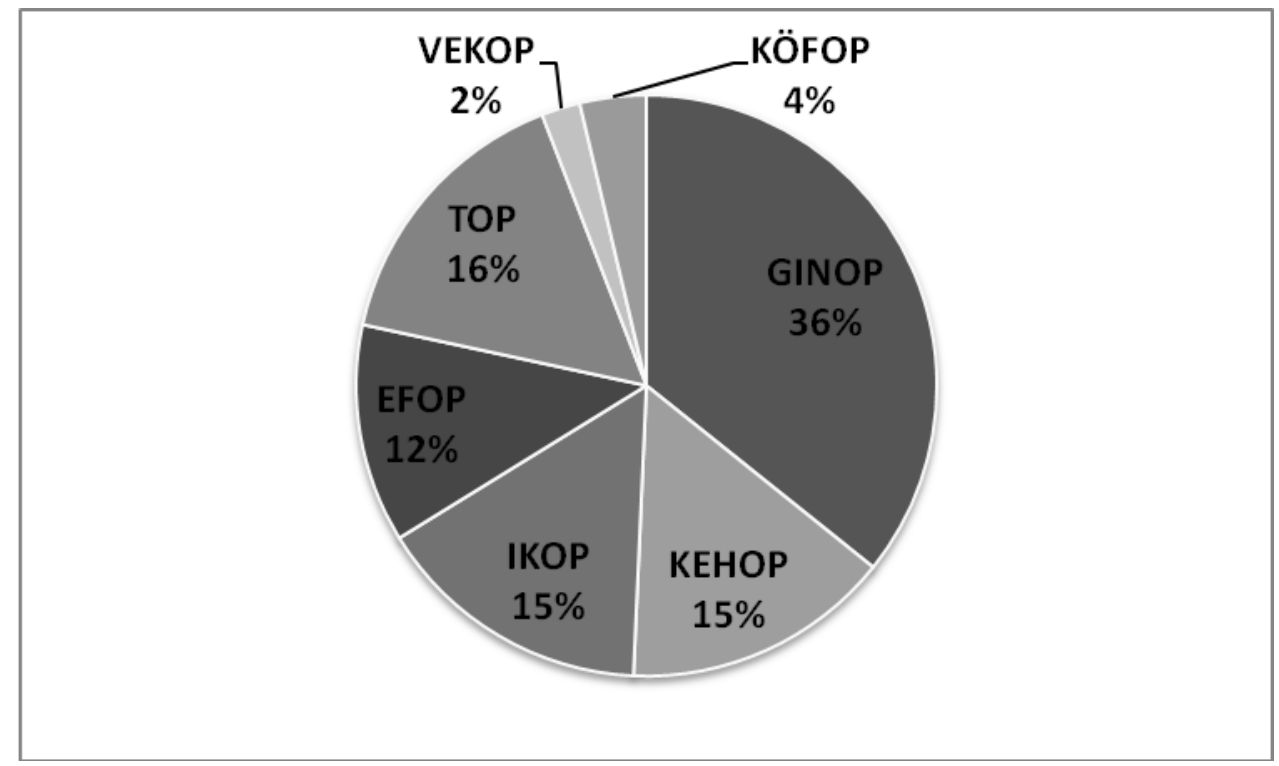

Forrás: Magyarország Kormánya: Az Európai Bizottság által elfogadott operatív programok 2014-2020;

http://palyazat.gov.hu/az europai bizottsag_altal elfogadott operativ_programok $2014 \quad 20$ Lekérdezve: 2015. augusztus 28.

A korábbi programozásban a GVOP, GOP elnevezést viselö programok jelenlegi megfelelöje a Gazdaságfejlesztési és Innovációs Operatív Program (GINOP). Sajátossága, hogy a korábbi időszakoktól eltérően duál-fund rendszerben itt jelenik meg a gazdaságfejlesztést érintő, ESZA keretében finanszírozható humán erőforrás fejlesztése is, pl. a vállalati képzések, munkaerő piaci re-integrációt jelentő programok. Ezeket a korábbi időszakainkban elkülönült alap kezelte. Ez a tény is alátámasztani kívánja azt a szándékot, miszerint a transzferek 60\%-a gazdaságfejlesztést fog szolgálni. Érdemi változást ugyan alig jelent, a 
nagyságrendek is hasonlóak, de a nevesített cél programjához rendelve már a 60\%hoz érdemi hozzájárulást mutat. A megyei programban is első fejlesztési területeként a gazdaságfejlesztést nevesítette. A projektlisták, projektcsomagok és a ténylegesen elért szereplők köréből az látható, hogy a nem agrár-alapú gazdaságfejlesztés szereplöit- különös tekintettel a KKV-kra - marginálisan érte el a közel két évig tartó területfejlesztési-tervezési időszak. Az alábbi ábra (7. ábra) jól szemlélteti a megyei projektcsomagokban számos esetben megjelenő lehatárolási kérdését, ami a Vidékfejlesztési Program (továbbiakban VP) és a GINOP közötti érdemi gazdaságfejlesztési kérdést jelent:

7.ábra: Élelmiszeripari támogatások lehatárolási szabály-rendszere

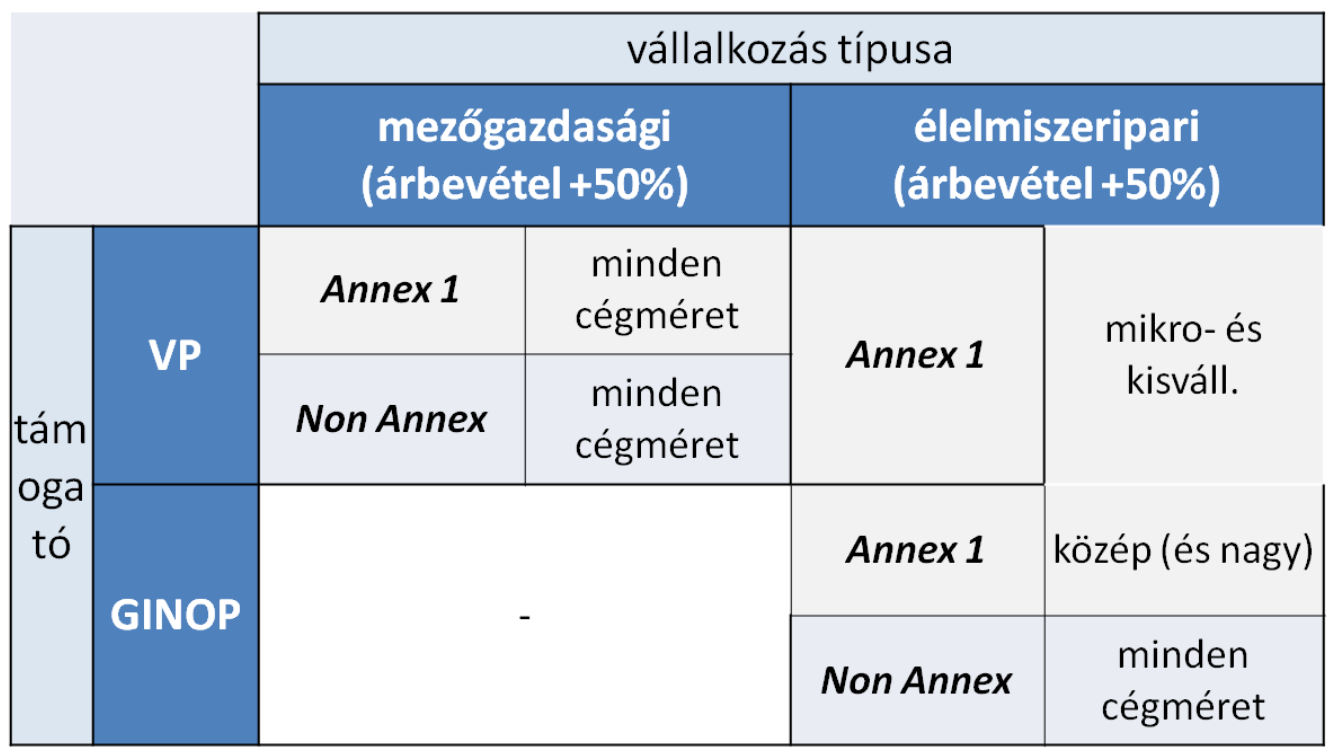

Forrás: Annex I.: az EK Szerzödés 32. cikkében hivatkozott lista

A Gazdaságfejlesztés még más programokban is megjelenik - hozzájárulva a kívánatos 60\%-os arányhoz. A Terület- és Településfejlesztési Operatív Program (továbbiakban TOP) első prioritásában megjelenő gazdaságfejlesztési lehetőségek az önkormányzati tulajdonú, a vállalkozási környezet ösztönzését jelentő fejlesztéseket támogatja (pl. ipari park vagy agrár-logisztikai park), míg a VP kizárólag vállalkozások egyedi vagy csoportos telephely fejlesztését támogatja, de agrárvonatkozásban. Az egyik legjobb hatékonysággal és felhasználási tapasztalatokkal rendelkező program újdonsága, hogy a korábbiakkal ellentétben itt kapott helyet a turizmus, mely már nem kiemelt támogatási terület uniós szinten, így a 
foglalkoztatás-növelés és egyéb gazdaságfejlesztési aspektus teljesítésével hozható helyzetbe ez a szolgáltató iparág. További jelentős újdonság, hogy a nyolcadik prioritás finanszírozhatja a más operatív programokból támogatást elnyert projektek saját forrását, és /vagy támogatás előfinanszírozási lehetőséget is ad kedvező kamatozású konstrukciók keretében. A lehetőség mind az önkormányzati, mind a for-profit szféra részére fennáll majd, mely elsősorban energetikai és egyéb infrastrukturális fejlesztések kiegészítő finanszírozására ad lehetőséget.

A gazdaságfejlesztést követően a második legnagyobb forráskerettel rendelkező, korábban hat önálló regionális operatív programban megfogalmazott tervezési egységet jelenti a Terület- és Településfejlesztési Operatív Program (továbbiakban TOP). A 2007-2013-as periódusban hat önálló regionális operatív programot alkotó fejlesztési program számos tervezési változás terhes következményét viseli, melynek intézményi vonatkozásai a tanulmány korábbi fejezetében kaptak helyet. A program tartalmát és forrásallokációját az alábbi felépítés szerint hagyta jóvá az Európai Unió Bizottsága:

1. Térségi gazdasági környezet fejlesztése a foglalkoztatás elösegítésére: Vállalkozásbarát, népességmegtartó településfejlesztés

2. Alacsony szén-dioxid kibocsátású gazdaságra való áttérés, kiemelten a városi területeken

3. A helyi közösségi szolgáltatások fejlesztése és a társadalmi együttműködés erősítése

4. Megyei és helyi emberi erőforrás fejlesztés, foglalkoztatás-ösztönzés és társadalmi együttműködés

5. Fenntartható városfejlesztés a megyei jogú városokban

6. Közösségi szinten irányított városi helyi fejlesztések (CLLD)

A prioritások a vállalt kötelezettségekre reagáltak, valamint arra a tervezési változásra, mely a megyéket nevesíti a fejlesztés alap-pilléreként. Ez nem csak önálló forráskereteket jelent, - az előző időszakban kiemelt projektek eljárásrendben szerepeltek a megye jogú városok fejlesztései - hanem a tervezési folyamatok első szintje is ez a közigazgatási szint. Itt került összegyüjtésre és nevesítésre az adott megye fejlesztési igénye, ezt követi a szaktárcában folyó országos szintü programalkotás. A VEKOP, vagyis a Versenyképes Közép-Magyarország Operatív Program azon ágazati fejlesztéseket is tartalmazza a fenti területfejlesztési tartalmon 
túl, ami fejlett gazdasági szintjére tekintettel nem szerepel(het) a most következő ágazati programokban. A Vidékfejlesztési Program (továbbiakban VP) meghatározó agrár-ágazati jellege mellett a 10.000 fő lakosságlétszám alatti települések TOP-pal közel azonos metodikában megjelenő helyi fejlesztési programjait tartalmazza, melynek jelentős ESZA tartalma is van, különösen a vidéki életminőség, azon belül is a szabadidős és kulturális fejlesztésekre különös tekintettel.

Ennek kiemelt területét „A helyi fejlesztés előmozdítása a vidéki térségekben” célrendszerben a LEADER helyi fejlesztések támogatása (CLLD - Közösségvezérelt helyi fejlesztés) adja. Megállapítható, hogy a TOP és VP kapcsolódnak legtöbb ponton egymáshoz. A TOP elsősorban a térség-központ funkciójú városok önkormányzati fejlesztéseire fókuszál, amely mellett a várostérségek vidékfejlesztést célzó intézkedések is megjelennek. Emellett a TOP ösztönzi az önkormányzati funkciók (közigazgatás, alapfokú egészségügyi ellátás, óvoda, stb.) energetikai fejlesztéseit is. A VP elsősorban a Helyi Akciócsoportok bevonása révén kapcsolódik a vidéki térségek munkaerő-piaci alkalmazkodásának elősegítésébe a helyi szintü foglalkoztatási paktumokban való részvételük által.

Végül van néhány olyan fejlesztési terület, amely egyaránt támogatható a TOP-ban és a VP-ben is. Ezek esetében területi-adminisztratív lehatárolást alkalmazzák: a VP finanszírozza a 6 . prioritáshoz definiált vidéki településeken megvalósuló fejlesztéseket (ld.VP 2.2 és 8.1 fejezet), a TOP pedig a nem vidéki településeken megvalósuló fejlesztéseket. Ezek az alábbiak:

• közétkeztetés infrastruktúrája,

- helyi piac,

- integrált fejlesztés (LEADER és TOP-CLLD)

A területfejlesztéssel szinte egyenlő fajsúlyú Környezeti és Energetikai Hatékonysági Operatív Programban (továbbiakban KEHOP-ban) számos analógia látható a korábbi időszak azonos programjának tartalmával, mely a környezeti derogációk, valamint az EU2020 energiahatékonysági kötelezettségeinek kettősségéből áll össze az alábbi megbontásban: 
1. A klímaváltozás hatásaihoz való alkalmazkodás

2. Települési vízellátás, szennyvízelvezetés és tisztítás, szennyvízkezelés

3. Települési hulladékgazdálkodással és kármentesítéssel kapcsolatos fejlesztések

4. Természetvédelmi és élővilág-védelmi fejlesztések

5. Energiahatékonyság növelése, megújuló energiaforrások alkalmazása

Sajnos a megyei projektlisták „kívánság lista” típusú megjelenítésén túl nem tartalmazott a szaktárcák számára egyéb szempontú megközelítést, meghagyva az egyes, az OP-k elözetes feltétel-rendszerének keretében kidolgozott ágazati stratégiákra alapozott projektszelekciót, tekintettel arra, hogy a beruházások nagy része a közszférát érinti, így nem nyílt, versenyeztetés alapú pályázati felhívások keretében történik meg a fejlesztések kijelölése.

A magyarországi vállalások három sarokpontját érinti ez a program, melyek az alábbi felépítésben használhatóak fel a következő években:

\section{Energiahatékonyság növelése}

A TOP vonatkozó intézkedései a kevésbé fejlett régiók valamennyi településén biztosítja az önkormányzati tulajdonú épületállomány energiahatékonyság központú rehabilitációját és az áttérést a megújuló energiaforrások alkalmazására. A kevésbé fejlett régiók megyei jogú városaiban területi korlátozás nélkül a TOP 6.5 intézkedése biztosít lehetőséget az önkormányzati tulajdonú épületállomány energiahatékonyság központú rehabilitációjára és a megújuló energiaforrások alkalmazására. Területi szükítés nélkül szintén a KEHOP 5. prioritás 2 intézkedése támogatja az állami (központi költségvetési) tulajdonú, az állami közfeladatot ellátó non-profit szektor, valamint a lakosság épületeinek energiahatékonysági, valamint megújuló energiaforrások alkalmazására irányuló fejlesztéseit. A GINOP 4. prioritása alatt a kevésbé fejlett régióban pedig a vállalkozások (kkv-k) épületenergetikai és megújuló energia felhasználás növelését célzó projektjei kapnak helyet.

Megújuló energiaforrások alkalmazása 
- KEHOP V. prioritás - 1., 2., 3. intézkedés: - Gazdasági társaságok mezőgazdasági üzemen kívüli, megújuló energetikai projektjei, hálózatra termelö, nem épülethez kötött zöldáram termelés; -. -Távhőszolgáltatók, távhőtermelő gazdasági társaságok, gazdasági társaságok távhő- és hőellátó rendszerek energetikai fejlesztése.

- TOP VI. prioritás: Önkormányzatok (kevésbé fejlett régióban) fejlesztései, önkormányzati többségi tulajdonú gazdasági társaságok fejlesztései (kevésbé fejlett régióban)

- GINOP II. /1.: az energetikai $\mathrm{K}+\mathrm{F}+\mathrm{I}$ fejlesztések

- GINOP IV. prioritás A gazdasági társaságok saját energiaigényük kielégítését szolgáló megújuló energia beruházásai

- GINOP VIII. prioritás A KEHOP V. prioritás és GINOP IV. prioritás intézkedéseihez kapcsolódó pénzügyi eszközök a kevésbé fejlett régióban

- VP, M1, M2:.: A mezőgazdasági üzemen belüli, megújuló energetikai projektek

- VP, M7. Megújuló alapú energiatermelés kisléptékü lokális rendszerek esetében

\section{$\underline{\text { Hulladékkezelés }}$}

- KEHOP III./1.,2.: Hulladékkezelési létesítmények hálózatának rendszerszerü fejlesztése; elkülönített gyüjtési és szállítási rendszerek fejlesztése

- KEHOP V./1.: villamos- és hőenergia előállítása az anyagában gazdaságosan nem hasznosítható hulladékokból (csak biológiailag lebomló)

- TOP II. és TOP VI.: hulladék anyagában történő hasznosítása érdekében hasznosítási kapacitások kiépítése önkormányzati többségi tulajdonú kedvezményezettek számára

- TOP II/2 és TOP VI.: Önkormányzatok kisléptékü környezetvédelmi infrastrukturális fejlesztései, lerakó rekultiváció 
- TOP II., TOP VI.: RDF termikus hasznosítása és települési maradék vegyesen gyüjtött hulladék égetéssel történő ártalmatlanítása

- GINOP VIII.: hulladék anyagában történő hasznosítása érdekében a hasznosítási kapacitások kiépítése KKV kedvezményezettek számára

A legnagyobb tartalmi változást a közlekedés-fejlesztés programjának (Integrált Közlekedésfejlesztési Operatív Program - IKOP) szükséges elviselnie. A kényszerítő kifejezés arra utal, hogy a 2007-2013-as programozási periódusban a két-és három számjegyü közútfejlesztések megvalósíthatóak voltak a Kohéziós Alap és az Európai Regionális Fejlesztési Alap forrásaiból, a jelen időszakban már csak az alábbi prioritások és tartalmi feltételekkel támogatható valamennyi közlekedésfejlesztés különös tekintettel az útfelújításokra:

1. Nemzetközi (TEN-T) közúti elérhetőség javítása

2. Nemzetközi (TEN-T) vasúti és vízi úti elérhetőség javítása

3. Fenntartható városi közlekedés fejlesztése és elővárosi vasúti elérhetőség javítása

4. TEN-T hálózat közúti elérhetőségének javítása

Ebben a kérdésben is tetten érhető a térségi igény megjelenítése kapcsán a korábbiakban jelzett problémák. A megyei programalkotók nem éltek a települési igény-listák kritikai megközelítésével, így egyfajta „kívánság listák” szerepelnek az egyes fejlesztés-típusok mellett. A túligénylést az a helyzet sem segítette elő, hogy a Partnerségi Megállapodás (továbbiakban PM) és a TOP Európai Bizottsággal zajló egyeztetése során a Bizottság kérésére rögzítésre került a PM-ben a közútfejlesztésre fordítható TOP források összegének maximális mértéke (összegszerüen hozzávetőlegesen 203 Millió EUR). Tekintettel arra, hogy a korábbi programozási időszak lehatárolási gyakorlatára túlnyomórészt a 2014-2020-as szabályozási keretrendszer is alapoz, a megyei koncepció jól azonosította a fejlesztési típusok ágazati besorolását. 
Az Emberi Erőforrás Fejlesztési Operatív Program (továbbiakban EFOP) elődei - az infrastrukturális és tartalmi fejlesztéseket az előző időszakban külön OP-k tartalmazták - az egyik legtöbb kritikát, megvalósítási nehézséget, összetettséget, ugyanakkor a szociális, egészségi, oktatási és kulturális téren kiemelkedő eredményeket felmutató programokként tarthatóak számon. A mono-fund rendszert megelőzően az első, csonka támogatási periódusban is ERFA és ESZA forrásokat egyaránt tartalmazó programmal rendelkeztünk, a Humán Erőforrás Fejlesztés Operatív Programjával. A fejlesztések „utódjai” ebben a hét éves periódusban a jogszabályi lehetőségeket kihasználva összevontan, az alábbi fókuszokkal kaptak bizottsági jóváhagyást:

1. Együttmüködő társadalom

2. Infrastrukturális beruházások a társadalmi együttmüködés erősítése érdekében

3. Gyarapodó tudástőke

4. Infrastrukturális beruházások a gyarapodó tudástőke érdekében

5. Pénzügyi eszközök alkalmazása a társadalmi együttmüködés erősítése érdekében, valamint társadalmi innováció és transznacionális együttmüködések

A marginális forráskerettel, 110450498 EUR, azaz 34,25 Mrd Ft keretösszeggel (310,1-es technikai Ft árfolyammal számolva) a Rászoruló Személyeket Támogató Operatív Program (továbbiakban RSZTOP) a többi programmal összehasonlítva elenyésző méretü, ugyanakkor újdonságtartalma miatt mindenképpen említésre méltó. Az RSZTOP elsődleges célja, hogy a leginkább rászoruló személyeket - a szegénységben élő gyermekeket, a hajléktalanokat, valamint a rendkívül alacsony jövedelmüeket- megfelelő étkezéshez és alapvető fogyasztási cikkekhez juttassa. A program azon EU 2020 célkitüzésre kíván reagálni, mely szerint „A szegénység kockázatának kitett lakosok számát 20 millióval kell csökkenteni”, és melyben hazánk a szegénységben élő népesség számának 450 ezer fővel történő csökkentését vállalta. 
A külön alapokat jelentő halászati és vidékfejlesztési programok, valamint a közigazgatási- és közszolgáltatás-fejlesztési program bizottsági jóváhagyása időben elvált a korábbi pontokban bemutatott tartalmaktól. Az agrár-fejlesztéseket, valamint az állami intézményi végrehajtás továbbfejlesztését finanszírozó operatív programok tartalma további közel fél éves egyeztetést követően véglegesedett, míg a halászati fejlesztési terv jóváhagyása tovább folytatódott. Fontos változás, hogy az egyik legnagyobb forráskerettel és eszköztárral rendelkező agrárprogram tekintetében a közös jogszabályi keretrendszer ide vonatkozóan - az ún. Friends of Better Spending javaslatának jóvoltából - kimondja, hogy „az európai strukturális és beruházási alapok müködésének összehangolása érdekében közös rendelkezéseket kell megállapítani az eddigi három alapon túl az Európai Mezőgazdasági Vidékfejlesztési Alap (EMVA), valamint az Európai Tengerügyi és Halászati Alap (ETHA) vonatkozásában is" [Hahn, 2013] és [EP és ET, 2013:320]. Ez egyfajta átláthatóságot és koherenciát jelenthet a kialakítandó tagállami szabályozásokban. A tavalyi évben elindult, és ebben az évben kiteljesedő folyamatokból az látható, hogy a korábban a Mezőgazdasági-és Vidékfejlesztési Hivatal gondozásában, és jogszabályi keretek között megjelent agrár pályázati kiírások felhasználói oldalról ugyanott, a kohéziós alapok fejlesztéseinek kiírásai mellett már nem jogszabályként, hanem pályázati felhívásként jelennek meg. Ez a változás már átláthatóbb, koherensebb és kevésbé nehézkes megoldást jelenthet az új programozási ciklusban.

\section{5 Összegzés}

A programozásban megfogalmazott új elvárások látszólag a minőségi költést is szolgálják, ugyanakkor a rugalmatlan, túlzott mértékü tematikus és pénzügyi elvárások és a programozási dokumentumok összhangba hozása a tagállami fejlesztési környezettel olyan mértékű kihívás elé állították az intézményrendszert, melynek csak úgy tudnak megfelelni az egyes szereplők, hogy a valódi, tartalmi tervezésre, újragondolásra alig maradt idő. Az abszorpciós szorítás, mely a tartalékképzés intézményével még kézzelfoghatóbbá vált, és az eredmény-orientált időközi számonkérés eltereli a figyelmet arról, hogy ésszerű felülvizsgálata történjék meg az eddigi folyamatoknak, valamint támogatott-szemszögü, szolgáltató-barát megközelítés sem mindig várható el az intézményrendszertől egy ilyen kiélezett, 
sarkított helyzetben. Ugyanakkor az intézményrendszer tagállamon belüli müködtetésében a Bizottság teljes tagállami szabadságot biztosít. Ez a túlzott mértékű „kilengésekhez” vezethet, mely csorbíthatja a hatékony és eredményes megvalósítást. Ez mind az intézményrendszeren belüli feladatmegosztás és a regionalitás kérdésében is helytálló. Sajnos Magyarország magán viseli mindkét típusú változás tekintetében a szélsőségeket. Egy megyei területfejlesztési program és a 2014-2020-as operatív programok találkoztatása során jól látható, hogy az újonnan megerősített megyei térségi szereplők nem képviselhették a megfelelö szubszidiaritási szintet. Ez a tervezés során megszólítottak körét és a programalkotók szakmai felkészültségét, kapacitását is mutatja, így nem szolgálhatott érdemi inputként a készülő OP-khoz, és nem testesítették meg a legitim partnerség kritériumának teljesítését. Jóllehet megjelenik az osztott-menedzsment fogalma jogszabályi szinten, ugyanakkor ebből a tagállamok másfél évvel a programozási időszak kezdetét követően még nem kaptak képet. Annak a veszélye az elmúlt évtized tapasztalati és az uniós tervezési folyamat ellentétes erőfeszítései ellenére is fennáll, hogy a fejlesztési források a támogatottak/kedvezményezettek szemszögéből ismét átláthatatlan és kevésbé illeszkedő módon kerülnek felhasználásra.

Az első részben megjelenő fejezetek az első hipotézis bizonyításához járulnak hozzá, miszerint az intézményrendszer kialakítását és müködését meghatározó jogszabályi rendszer determinálhat hatékonysági problémákat, megjelenítetve az uniós szintű és hazai szabályozás következményét is.

\section{II.RÉSZ}

\section{ESETTANULMÁNY ÉS ESETLEÍRÁSOK A HAZAI TÁMOGATÁS- FELHASZNÁLÁS ÉVTIZEDÉBÖL}

A második rész két fejezete a hazai támogatás-felhasználás egy évtizedet meghaladó történelmének része. Mindkét fejezet az adekvát szubszidiaritás és legitim partnerség 
hipotéziseinek bizonyításához kíván hozzájárulni. A téma relevanciája szerint a hipotézisek bizonyításának szempontjából legerösebb érvanyaggal rendelkező esetleírásokat dolgozom fel értekezésemben, lehetőség szerint nemzetközi összehasonlítással kiegészítve. Az átfogóbb esettanulmány kertében egy intézményi szereplő összehasonlító szintézisét dolgoztam ki a szakirodalomban erre vonatkozó javaslatok szempontrendszerével. A térségbe illesztett non-profit tanácsadó rendszert 2007-ben a Bizottság Regionális Főigazgatósága tagállami jó gyakorlatnak minősítette, a közel egy évtizedes munkájának elemzése az alábbi hipotéziseim bizonyításához járul hozzá:

H2a: Az intézményrendszer müködésében, müködési struktúrájában érvényesített adekvát szubszidiaritás és legitim partnerség javítja a hatékony felhasználást.

$\mathrm{H} 2 \mathrm{~b}$ : A programtervezés, projektgenerálás, projektkiválasztás során megjelenő adekvát szubszidiaritás és legitim partnerség javítja a hatékony felhasználást.

H2c: A projektmegvalósítás során alkalmazott adekvát szubszidiaritás és legitim partnerség javítja a hatékony felhasználást.

\section{FEJEZET}

\section{ILLUSZTRATÍV ESETTANULMÁNY: A PROGRAMSZINTÜ HATÉKONYSÁG JÓ GYAKORLATA - ELMÉLETI MODELL ÉS INTÉZMÉNYI SZEREPLŐ ÖSSZEHASONLÍTÁSA}

\subsection{Az elemzés alapjai}

A fejezetben egy tagállami jó gyakorlat hazai adaptációját mutatom be illusztratív esettanulmányként (CAPAM [2010]).

A szakirodalom az ír „tudás-transzfert” nevesíti a legjobb gyakorlatok között, ehhez hasonló Lengyelországban is kialakításra került Know-How Fund néven. A módszer lényege mindkét tagországban, hogy a kohéziós források felhasználásban olyan tudás-és tapasztalat-átadási láncot hozzanak létre, melyek elősegítik a támogatások szabályos, átlátható, gyors lehívását és az eredményes megvalósítást, összekapcsolva az intézményrendszeri oldalt a megvalósítás szereplőivel. Teszler B. István 2005- 
ben Az Európai Unió külsö fejlesztési alapjaiban való hatékony magyar részvétel az integráció-érettség tükrében címü doktori értekezésében kidolgozott egy javaslatot, egy rendszer szemléletű müködés-támogatási modellt az előcsatlakozási alapok és a HEFOP kezdeti tapasztalatai alapján (Teszler [2005]). Kutatása során rávilágított arra, hogy uniós tagságunk által elérhetővé váló kohéziós alapokkal nemcsak a források - és ezáltal a problémák - többszöröződnek meg, hanem egy minőségi váltás is bekövetkezik a programozás, pályáztatás, menedzsment területén mindhárom oldalon, vagyis az irányítói (államigazgatás), a felhasználói (vállalkozók, önkormányzatok, NGO-k) és az őket összekötő szakmai közvetítő-támogató oldalon. Teszler B. István disszertációjában rámutat arra, hogy a tudás kiszerződése hozza felszínre annak a tudásnak az integrált hiányát, ennek alapján a programozásvégrehajtás területén az alábbi kritikus területeket azonosította:

- Programozás, pályázat-előkészítés;

- Pályázati alapinformációk disszeminációja;

- Formailag (és tartalmilag) megfelelő pályázatok készítése;

- Pályázatok értékelése, az elöértékelés (assessment);

- Támogatott projektek menedzselése;

- Szerződésmódosítási kérdések;

- Belső beszerzések menedzselése;

- Pénzügyi menedzsment;

- A megszerzett menedzsmenttudás és tapasztalatok disszeminációja.

Teszler B. István rendszer-szemléletü müködés-támogatási modellje egy irányító hatósághoz rendelten került kidolgozásra egy „ISO-szerű minőségirányításminőségbiztosítás" alapú megközelítésben annak érdekében, hogy az Irányító Hatóság a „közhatalmi” felfogásból „közszolgálati” irányt vegyen. Javaslata alapján szükséges elmozdulni egy köztes irányba, mely objektíven mérhető teljesítményparaméterekkel közelíti az irányítási és megvalósítói oldalt. A szerző a fenti jelenség orvoslására az állami intervenciók erősítését írja elő információ-transzferrel, (belső és külső) tudás-transzferrel, kapacitásépítéssel, valamint javasolja egy horizontális, „peer-to-peer” típusú, rendszer-támogató tudás-és tapasztalat-átadó hálózat létrehozását, mely megközelítés az eddigiek során teljességgel hiányzott a hazai gyakorlatból. 
Kritikai észrevételként jelezni szükséges, hogy a kizárólag egy operatív programra kidolgozott javaslat - annak átfogó tartalma ellenére - nem kezeli a teljes, NSRK szinten azonosított és feltárt hiányosságokat. Ezek OP-k szinten ismételt kialakítása viszont sem költséghatékonyság, sem átláthatóság szempontjából nem segítette volna elő a megvalósítást. Ugyanakkor a disszertációban 2005-ben, vagyis az első hazai tört-időszaki programozási időszak alapján megalkotott elméleti modell és javaslatcsomag az elmúlt tíz év tapasztalatai tükrében figyelemre méltó megállapításokat és előrejelzéseket adott.

Így az esettanulmányomban vizsgálni kívánt intézményi szereplőt a Teszler-féle elméleti elvárások mentén elemzem a három, hazánk számára már tagországként megnyílt fejlesztési források programozási periódusaiban.

\subsection{Programszintű példa a hazai intézményrendszerben}

A tudás-transzfer hazai gyakorlatát megvalósító, a 2007-2013-as fejlesztési időszak Végrehajtás Operatív Program (továbbiakban: VOP) keretében müködtetett Nemzeti Fejlesztési Terv Kistérségi Tanácsadói Hálózatát az erről szóló 344/2007. (XII. 19.) Kormány rendelet hozta létre, rögzítve, hogy a Kormány az uniós fejlesztési források és a hazai területi alapú támogatások felhasználásának elősegítését, a kistérségek együttmüködési tevékenységének fejlesztését, a hátrányos helyzetü kistérségek felzárkózásának gyorsítását a Kistérségi Koordinációs Hálózat (a továbbiakban: Hálózat) müködtetésével látja el. A rendelet $5 \S$ (4) bekezdése nevesítette a feladatkört a Hálózat helyi munkatársai, - a kistérségi koordinátorok - számára, ezekből az alábbiak, az uniós fejlesztésekre vonatkozóak képezik a Teszler-féle elméleti javaslatok és szakaszok összevetésének alapját:

$5 \S$ (4) b) a Vidékfejlesztési Tanácsadói Hálózat szakembereivel közösen, egymással egyeztetett feladatmegosztásban közremüködik a fejlesztési projektek azonosításában, előkészítésében és megvalósításuk támogatásában;

c) a Vidékfejlesztési Tanácsadói Hálózat szakembereivel közösen, megfelelő rendszerességgel, ügyfélszolgálati napot tart; 
d) tájékoztatást ad a folyamatban levő hazai és közösségi pályázati lehetőségekről, a pályázatokkal összefüggő finanszírozási kérdésekről, a területfejlesztési kompetenciába tartozó elfogadott tervek tartalmáról;

e) külön felkérés alapján adatokat gyüjt a terület- és regionális fejlesztés megalapozásához, a fejlesztési elképzelések kidolgozásához;

f) a fejlesztések sikeres megvalósítása érdekében rendszeresen tájékoztatja a regionális hálózati igazgatót a kistérségi szereplőktől érkező javaslatokról, kezdeményezésekről, kérdésekről;

g) területfejlesztési szempontból figyelemmel kíséri és értékeli az Új Magyarország Fejlesztési Terv (a továbbiakban: ÚMFT) operatív programjainak megvalósulását, valamint a decentralizált területfejlesztési források felhasználását;

h) figyelemmel kíséri a kistérségben előkészítendő jelentősebb fejlesztési projekteket az ötlettől annak megvalósításáig, közremüködik a projektek kidolgozásának, szükség esetén a projektek átdolgozásának ösztönzésében, szervezési segítséget nyújt ezek kidolgozásához, pályázatok benyújtásához;

i) közremüködik a központi közigazgatási szervek, a többségi állami vagy önkormányzati tulajdonú, illetve fejlesztési tanács által alapított, fejlesztéssel foglalkozó gazdálkodó szervezetek, valamint nonprofit szervezetek, önkormányzati szövetségek, kamarák, országos kisebbségi önkormányzatok kistérséget érintő programjainak megvalósításában;

j) közremüködik a nemzetközi, hazai és kistérségi területfejlesztési források felkutatásában, azok koordinált felhasználásában, a kitüzött területfejlesztési célok szerinti hasznosításában;

Teszler B. István rendszer-szemléletű müködés-támogatási modelljében azonosított kritikus területek szerinti tanácsadó hálózati tevékenység bemutatása a 2007-2013-as programozási periódus tapasztalatai alapján. 
1.3 A Teszler-féle elmélet és hazai intézményi gyakorlat szintézise tagságunk első tíz évében

\subsubsection{Programozás, pályázat-előkészítés}

A kiindulási alapot az képezte elméleti modelljében, hogy az ugyanazon célért hatékony forrásfelhasználásért - dolgozó szereplők „nem egy nyelven beszélnek”, nem rendelkeznek rálátással és tapasztalatokkal a másik csoport munkáját illetően, vagyis a programirányítói oldal és a pályázói/kedvezményezetti oldal között szemléleti-kulturális probléma lép fel. A probléma feloldását háromféle eszközzel javasolta megtenni: egy felhasználó-barát időszaki visszajelző rendszerrel (kérdőíves, nyilvános konzultációk), terepmunka-rotációs rendszerrel és gyakornoki rendszerrel.

A Kistérségi Hálózat munkatársai alapfelállásukat tekintve a kiinduló problémára reagáltak, vagyis az irányító és a felhasználói oldal között elhelyezkedve, a Nemzeti Fejlesztési Ügynökségen belül egy önálló szervezeti egységként, ugyanakkor valamennyi kistérségben általában a Kistérségi Fejlesztési Társulásoknál irodát fenntartva tanácsadói szerepkörrel a pályázók és kedvezményezettek rendelkezésére állva kaptak visszajelzéseket a rendszer müködéséről. Ez történt irányított kérdőíves megkérdezésekkel vagy nyilvános tájékoztató napok keretében egy-egy célcsoporthoz (pl. vállalkozók vagy önkormányzatok), illetve témához (pl. pályázati kiírás, vagy tematika - pl. megújuló energiák) rendelten. A LAU I-es szint megfelelő méretü ahhoz, hogy a megkérdezések hatékonyak tudjanak lenni, értem ez alatt a megfelelö célcsoporti lefedettséget, érdemi szereplök megszólítását, azaz azon munkatársak bevonását, akiknek munkaköréhez tartozott a fejlesztési terület műszaki munkatársak, projektiroda dolgozói. A Hálózat munkatársai a visszajelzéseket feldolgozható és összesíthető formában juttatták vissza a központi irodába, akik az Irányító Hatóságok számára továbbították az információkat. A regionális szinten létrehozott központok véletlenszerü kiválasztással mérték, a pályázók és kedvezményezettek mennyire voltak elégedettek a kistérségi munkatársak munkájával, mennyiben segítette elő tájékozódásukat, problémamegoldásukat és az intézményrendszeri kommunikációt, átláthatóságot.

A modell további két javaslata, a rotációs rendszerü terepmunka és a gyakornoki program. Ezek szándékolt módon, vagyis feladatkör jellegüen nem valósultak meg, 
jóllehet volt esetenként átjárás a rendszerben mindkét irányban; kistérségi munkatárs szakmai előéletét tekintve rendelkezett egyéb intézményi - akár irányító hatósági, akár közremüködő szervezeti - tapasztalattal, és az intézményrendszer is „olvasztott magába” hálózati terepen dolgozó kollégát. A konkrét esetek azt mutatták, hogy mindkét irányú mozgásnak, tehát a Teszler-féle értelmezés szerint a terepmunkának és a gyakornoki programnak is jelentős pozitív hozadékai jelentkeztek, melyek a hatékonyságot segítették elő: a „miért-eket” segítették megérteni mindkét oldalon, empátiát keltett a másik oldal problémái iránt és növelte az ügyintézési gyorsaságot az illetékes intézményi kolléga közvetlen elérhetősége által. A párbeszéd fel tudott gyorsulni, kiiktatva a Help Desk típusú közvetítői megközelítést.

\subsubsection{Pályázati alapinformációk disszeminációja}

A Teszler-modell ebben a fejezetben két problémát azonosított; a pályázatok meghirdetése országos napilapokban és az internetes felület önmagában nem elégséges a megfelelő célcsoport eléréséhez és a pályázatok értelmezéséhez, ezért szükséges kialakítani és karbantartani egy disszeminációs tudásbázist a potenciális pályázókról és kedvezményezettekről és személyes/személyre szabott megkeresések és elérések formájában primér támogatási szintet kell létrehozni.

A Kistérségi Hálózat a fejezetben megfogalmazottakat teljes mértékben lefedi, jóllehet megfigyelhető egy átmeneti tanulási szakasz és tapasztalat-átadási metodika kifejlesztésének időszaka. A három célcsoport (vállalkozások, önkormányzatok és civil szervezetek) adatbázisa a két utóbbi csoportnál teljes körúen kialakult a 200713-as programozási időszakra, a vállalkozások esetében egyre jobb térségi beágyazódással a cégek adatbázisa folyamatosan bővült, jóllehet ennek karbantartása a szűkösen rendelkezésre álló kapacitásokat más, indokoltabb tevékenységektől vette el.

A célcsoportok elérése közvetlenné és azonnalivá vált, célzott e-mail-es értesítéseket kaptak a kizárólagosan őket érintő pályázati információkról általában még a megjelenés napján, melyeket továbbiak követték a kiírások módosulásakor. Gyakorlattá vált pl. a valamennyi önkormányzati vezetőt (polgármestert és/vagy jegyzőt, nagyobb városok esetében illetékes munkatársat) tömörítő Kistérségi Fejlesztési Társulások ülésein önálló napirendi pontként beszámolni a pályázati aktualitásokról. 
Az adatbázis létrehozása és a személyes elérések mellett a munkatársak felkészítését írta elő az elméleti modell az adekvát informálás érdekében. Ennek rendszere meglehetősen esetleges volt és személyfüggő, a gyakorlat e tekintetben (is) egy fejlődési ívet járt be a Teszler által is azonosított akadémikus uniós ismeretek oktatásától eljutva a konkrét jogszabály értelmezések és szakpolitikai irányelvek elsajátítását is igénylö háttérismeretek megszerzéséig. A tényleges müködés során kiforrott egy peer-to-peer típusú tudás-transzfer módszer a kollégák között, mely a különböző szakterületekre tömörítette az elöképzettséggel, tapasztalatokkal rendelkező munkatársakat, akik csoportokban feldolgozták a pályázati felhívások mögötti szakpolitikát, a használt fogalmakat definiálták, közérthetővé és átadhatóvá tették kollégáik számára, akik a saját kistérségükben élő célcsoportnak rendeztek tájékoztató fórumokat.

A müködéshez egy szoftver is kialakításra került, ahová lehetséges kedvezményezetti adatbázis feltöltése és régiós szintü adatkezelés is megvalósult, valamint a munkatársak tevékenységének monitoringja, amely lehetővé tette a Teszler által is preferált teljesítmény-alapú elszámolást. Ez utóbbi kritikája az adminisztráció túlzott aránya a tényleges szakmai munka rovására. Ennek kiváltásaként több személyes ellenőrzés, egyeztetett és elöre be nem jelentett módon is hatékonyabb megoldás lehet.

\subsubsection{Formailag (és tartalmilag) megfelelő pályázatok készítése}

A programozás-végrehajtás kritikus szakaszaként azonosított folyamatrészben a modell abból az alapproblémából indul ki, hogy az általános támogató eszközök (az útmutatók, a Help Desk szolgáltatások és az infonapok) elégtelen volta determinálja a beadandó anyagok minőségét, jóllehet szakmailag megfelelő elképzelésről lenne szó, de nem felel meg a formai elvárásoknak, vagy a pályázók nem megfelelően értelmezett kötelezettségeket vállalnak. Sajnos a pályázati útmutatók nagy hányada klasszikus, akadémikus tudást közvetít, elvonva az időt és figyelmet a pályázók számára lényegi részektől - vagyis a lehetőségektől és kötelezettségektől. Első megoldásként a szcenárió alapú pályázati útmutató alkalmazását írja elő Teszler, ami azt jelenti, hogy a pályázás-végrehajtás folyamatát követő kézikönyv a gyakorlatra jól átültethető, példákat felvonultató és a valós problémákkal összekapcsolható támogató eszközként jöjjön létre. 
Jóllehet az első Nemzeti Fejlesztési Tervhez képest történt elmozdulás 20072013-as programozási periódusra, de nem történt meg a modell szerinti újrastrukturálás; a pályázati útmutatók továbbra is akadémikus tudást és fogalomhasználatot tükröztek, a tagolása továbbra is tematikus ( $\mathrm{pl}$. pénzügyi, indikátorok) maradt, ezért a kezelhetőséget és átláthatóságot nem szolgálta. A Hálózat munkatársai azonban jelentős szerepet játszottak a modellben elöírtak megvalósításában. Amit nem változtattak a kiadványok szintjén, azt tőlük a gyakorlati közeg szükségszerüen elvárta, vagyis a kollégák úgy mutatták be tájékoztató napok keretében a pályázati kiírásokat, hogy feldolgozták az útmutatókat, sablonokat, mellékleteket és konkrét megvalósítási formákra ültették rá az elméleti elvárásokat. A tájékoztató napok résztvevői kikerülhetetlenül a saját projektjük szemszögéből kértek megoldási javaslatot, vagyis megvalósult a szcenárió alapú megközelítés. A kistérségi munka a korábbi pontokban leírtakhoz hasonlóan itt is proaktívan, saját kezdeményezésből alakult ki, vagyis nem - vagy ritkán - történt meg, hogy az illetékes közremüködő szervezet (KSZ) által előre elkészített előadás-sablonnal tudtak dolgozni a pályázati kiírások bemutatása kapcsán. Számos alkalommal a kollégák munkacsoportokba rendeződve saját kidolgozás keretében készítettek el egy-egy tájékoztató anyagot. Tapasztalható volt egy kétszintű munkamódszer, melynek első szakaszában a pályázati kiírás olyan típusú megközelítése történt meg, amely a pályázói érdeklődést kívánta felkelteni a pályázati kírás értelmezésével, majd a valós igények alapján egy magasabb szintü egyeztetés zajlott tényleges pályázati elképzelések végiggondolásával a formai, jogosultsági kritériumok tükrében. Megvalósult az elméleti modell elvárása, egy konkrét pályázati megoldáson végighaladva történt a résztvevők bevonása, vagyis minta alapján a teljes forgatókönyv szerinti pályázati bemutatás történt meg a kistérségi tájékoztatók keretében. Az alkalmakat olykor megelőzte egy budapesti, a közremüködő szervezet által rendezett infó-napon történő részvétel, ahol a kistérségi munkatárs sok olyan szakmai háttér információval is szembesült, mely elősegítette a kiírói szándék megértését.

A modell másik javaslata a fent nevezett problémára egy Private Consulting rendszer felvázolása volt. A magán tanácsadói szférából akkreditáció révén létrehozandó és ingyenesen, szakértői napok keretében lehívható „pályázatíró- és projektmenedzsment-pool" ötletének létjogosultságát a tényleges gyakorlat számos esetben igazolta. A magántanácsadói szféra munkájának heterogenitása 
következtében gyakorta a Hálózat munkatársaira „hárult” a menedzsment problémák kezelése tanácsadói piac felhígulása következtében. A munkatársak olykor „belecsöppentek” kész helyzetekbe, melyeket válság-menedzsment szinten orvosolni volt szükséges az elégtelen pályázatírói munka következtében. A tanácsadói szféra nagy hiányossága a helyismeret, szinergiák és hosszútávú gondolkodás elégtelen volta. Az adott feladaton sikerdíjért dolgozó tanácsadó cég sok esetben arra koncentrált, hogy megnyerje pályázatot, ugyanakkor olyan kötelezettségeket vállalt a megbízó nevében - pl. az indikátorok vagy horizontális elvárások szintjén-, amelyek teljesíthetetlensége csak a megvalósításkor vált világossá a kedvezményezett számára. Ekkor a térségi szereplővel kapcsolatban lévő térségi hálózati munkatársakat kérték, hogy közremüködjenek a vállalások enyhítésében, kiváltásában, hiszen a tanácsadó cég szerződése ekkorra már lejárt, teljesítésigazolással rendelkezett a cég, önkormányzat vagy NGO részéről. Az elméleti modellben felvetett javaslat a gyakorlatban is racionális hatékonysági kérdés, mely szerint a projekt keretében ingyenesen lehívhatóvá váljon egy minőségileg garantál projekt menedzsment tevékenység.

\subsection{4. Értékelés (assesment)}

A pályázatok bírálati szakaszára megfogalmazott elméleti javaslatok döntően megvalósultak, bírálói keretszerződések és szakértői napok igénybevétele áll a közremüködő szervezetek rendelkezésére, a két éves akciótervi időszakokra kidolgozott pályázati kiírások értékelése a ciklusok előre haladásával egyre gördülékenyebben történtek. E szakaszoz a Kistérségi Hálózat kapcsolódása ott mutatható ki a gyakorlati tapasztalatok alapján, hogy a munkatársak a döntést követően nyilvánossá váló bírálatot a pályázó számára kontrollálják és értelmezik. Ez az elutasított pályázatok esetében merült fel jelentős igényként a pályázók részéről, és történt olyan eset, amikor e tevékenység keretében az értékelés felülvizsgálatra került a panasz intézményrendszerén keresztül és támogatói határozattá módosult az elutasító döntés. E megtartandó gyakorlaton túl szükségesnek látok egy továbbfejlesztési lépést, mely a pályázati szakasz tájékoztatási munkáját segíti elő azzal, hogy az értékelők felkészítésébe tematikus jelleggel néhány hálózati kolléga bevonását valósítja meg. A módosítási javaslatom a hatékonyságot annyiban segíti elő, hogy az elvárások megismerése már az indulási szakaszban megtörténik és 
disszeminálhatóvá válik a kollégák között annak érdekében, hogy a pályázók felkészítését mindinkább a kiírások szellemében tegyék.

\subsubsection{Projekt végrehajtás}

A Teszler-modell készítésekor még az első hazai fejlesztési terv sem járt abban a szakaszban, hogy a végrehajtáshoz jelentős gyakorlati tapasztalatok társuljanak. Mégis megállapítható, hogy a megjósolt problémák valamennyi területen (a támogatott projektek menedzselése, szerződésmódosítási kérdések, belső beszerzések menedzselése és a pénzügyi menedzsment) tendenciálisan bekövetkeztek. A megvalósítás jelen szakaszának tükrében kijelenthető, hogy a szerző által javasolt innovatív elemek alkalmazása megelőzte volna az eredményességet is befolyásoló jelenségek kialakulását. A szerződés-szerü végrehajtásnak a modellben felvázolt eszköztárát a Kistérségi Hálózat munkájának fényében kívánom elemezni;

- szcenárió alapú projekt menedzsment útmutató létrehozása: a közremüködő szervezet kompetenciájaként, opcionálisan készített útmutató sok esetben tükrözte a pályázati útmutatók fejezetnél említett problémákat. Ugyanakkor a kedvezményezett és a közremüködő szervezet között ebben a szakaszban már ki tudott alakulni egy iteratív folyamat a megvalósítási problémákról, amennyiben azt az első fél kezdeményezte, így a kistérségi munkatársak bevonása ritkán történt meg. Jellemző volt azonban a lassú átfutási idő, mellyel a problémák túlhaladottá váltak, a megoldatlan helyzetek újabbakat generáltak. A rendszerbe javasolt lenne a hálózati munkatársak olyan mérvü bevonása, mely a pályázati szakaszban már kialakításra került, hiszen sok esetben a grant sheme-típusú projektek esetében nem egyedi problémák jelentkeznek a kedvezményezetteknél, így típus-példák és azok megoldási javaslatai elsajátíthatóak lennének, ez a közremüködő szervezet munkatársait is tehermentesítené a „rutin” feladatoktól. A hálózati kollégákat a KSZ-ek eltérő intenzitással vonták be, eset-jellegüen, és így a tényleges leszabályozás és munkamódszer kidolgozásának hiányában teljesen egyéni fejlődési pályát járt be.

- peer-to-peer támogató csoport: „azonos státuszúak” menedzsment csoportjaként azonosítja Teszler az eszközt, mellyel már a pályáztatási szakaszban is foglalkozott. A tudás-és tapasztalat-transzferen alapuló 
megoldás itt is a hálózat munkája lehet, akik a pályázati szakaszhoz hasonlóan, a KSZ-ek által felkészítetten helyi szinten tudnak tájékoztatókat szervezni a kedvezményezettek számára a jelölt témakörökben. Ennek gyakorlati megvalósítása a 2007-2013-as időszak második felére alakult ki, amikor a támogatási szerződések tömegessé válásával a problémák is hatványozottan jelentkeztek, és olykor már csak a helyszíni ellenőrzések folyamán derült fény.

- tanácsadó-banki szolgáltatás: szintén a pályázati szakaszhoz visszanyúlva írja elő Teszler a „szakértői pool”-ok léterhozásának rendszerét, a tenderek bonyolításához és az időszaki beszámolók készítéséhez. Míg az első feladat, vagyis a közbeszerzések területe valóban szakértőket igényel és jogos a felvetett megoldás, addig a beszámolók készítésének (előrehaladási- és zárójelentések) kérdése teljesen hozzárendelhető a hálózati munkához. Ide tartozik a támogatási szerződés módosításának és pénzügyi változásoknak a kérdése is, melyek nem egyértelmüen sorolhatóak be valamely kategóriába, tekintettel arra, hogy széles skálát járhat be a felmerült probléma. A megoldást abban látom, hogy a hálózati munkatárs a probléma értelmezését követően tudja eldönteni, hogy helyi szinten saját hatáskörében tudja-e a helyzetet orvosolni, vagy csak a probléma pontos leírását teszi meg és juttatja el a közreműködő szervezeti munkatárs részére.

- kockázat-elemző, kockázat-menedzselő rendszer létrehozása: „standardizált veszély-paraméterek" mentén korai jelzőrendszer kiépítése a projektvégrehajtás mentén. A 2007-2013-as időszakban az ellenörzés és monitoring a közreműködő szervezetek feladatkörébe tartozik, kockázatbesorolás alapján kategorizálva a látogatások rendszerességét és mélységét. Tekintettel azonban a projektek nagy számára elmondható, hogy az ellenőrzések legtöbb esetben már akkor történtek meg, amikor olyan fokú hiányosságot tártak fel, mellyel a projekt folytathatósága kérdésessé vált. A problémák elörejelzése a kedvezményezettek részéről több okból nem történt meg; adminisztratívan túlterhelt rendszerben nem futott át kérdés a helyszíni ellenőrzésig; félelem a hatósági magatartást tanúsító közremüködő szervezettől; szándékolt elrejtése a problémának. Az utolsótól eltekintve a hálózati munkatársak bevonása ebbe a szakaszba jelentősen segítené a hatékonyságot azzal, hogy rendszeres projektlátogatással ki tud alakulni egy 
bizalmi viszony és egy gyors jelzőrendszere a módosításoknak, vagyis nem a KSZ monitoring látogatása keretében derülne fény a szerződéstől eltérő teljesítésre, hanem még a változtatás megtörténte előtt, előre egyeztetett módon, a helyzetre gyorsan reagáló projekt-menedzsment zajlik a kistérségi munkatárs együttmüködésével. A munka szakmai hátterének elsajátításához és az ellenőrzések forgatókönyvének megismeréséhez szükséges lenne, hogy a helyi hálózati munkatárs meghívást kapjon a térségében zajló KSZellenőrzésekre is.

\section{3. 6. A megszerzett menedzsmenttudás és tapasztalatok disszeminációja}

Az elméleti modell tapasztalatcserén alapuló multiplikátor-képzéseket javasol az elearning eszközének bevonásával a korábbi fejezetekben leírt módon (szcenárióalapú, „peer-to-peer” típusú, stb.). A non-profit hálózat munkatársai már ebben az időszakban megvalósították a célcsoportok megfelelő elérését, gyakorlat-orientált felkészítését és folyamatba-épített, iteratív és adekvát ismeretátadását, melyhez az elearning eszközei is hozzájárultak, elsősorban a tudásfelmérések szintjén. Standardizált tudás azonban még nem tudott kialakulni, mert nem egy központosított képzés keretében történtek a hálózati munkatársak gyakorlat-orientált felkészítése, hanem munkacsoportokba szerveződve, maguk számára készítették el a tájékoztatókon átadni kívánt tudást, így ennek megfordítása és általánossá tétele valós igény lenne a Széchenyi programiroda keretében végzett tevékenység ellátásához 2014-2020-as időszakra.

A fejezet kitér a kommunikációra, mint a szakmai és társadalmi siker elérésének kihagyhatatlan eszközére, megkülönböztetve a funkcionális - vagyis a szakterület szereplőinek szóló - és a média-nyilvánosságot. A siker feltétele mind az első, vagyis az eredményességet mérő és az utóbbi, az eredményességet megítélő közeg megfelelő megszólítása. A 2007-2013-as időszakra e tekintetben is jelentős központi egységesítés zajlott le az ún. Arculati kézikönyvek és a szerződéses szabályozások szintjén. A gyakorlatban azonban az a tapasztalat, hogy a megjelenítésben a célcsoporti elérések és a kommunikációs tartalmak elcsúsztak, így jelentős beruházások és fejlesztések nem kerültek át a köztudatba, nem kapcsolták őket össze az uniós forrásokkal, áthelyeződött a hangsúly a problémás projektek 
médiaszereplésére, holott arányát tekintve ezek nem haladták meg a tagállami átlagokat.

A hálózati munkatársak eddigi tevékenységében egy helyi média-figyelő és visszajelző rendszer került kialakításra, melynek fenntartása indokolt, és kiegészítésre szorul a fenti problémák kezelése érekében. A hírek helyi beágyazottságának megítélésében - vagyis a célcsoporthoz leginkább illeszkedő médiafelület kiválasztásában - és a hirdetéstartalmak előzetes kontrolljával jelentősen hozzájárulnának a kommunikáció hatékonyságának, ezáltal a támogatások valós megítélésének elősegítéséhez. Szintén megfelelő kompetenciával rendelkeznek az ún. minta-projektek kiválasztásához, melyek országos megismertetése szintén a közvélemény kedvező megítélését szolgálják.

1.4 Széchenyi 2020 Ügyfélszolgálat - Fejlesztett megoldás az új programozási időszakra

A jelen programozási periódusban müködő non-profit tanácsadó hálózat kapcsán kvalitatív mélyinterjúk segítségével törekedtem a változtatások bemutatására. Kérdéseim fókusza a hatékonyság-központú változásokra, ezen jellemzők érvényesülésének alakulására vonatkoztak. Kétfajta interjút folytattam le ennek keretében: adott térségi munkatárssal, valamint a Nemzeti Fejlesztési Minisztériumból Bogáti János miniszteri biztossal, aki járási kormányhivatal vezetőként, és korábbi hálózati tanácsadóként is átfogó rálátással rendelkezik a folyamat alakulása tekintetében.

Különösen az 2007-2013-as időszakra megfogalmazott alábbi szempontok követése állt vizsgálatom fókuszában:

- intézményrendszeri (IH, KSZ) munkatárs terepmunkája a Hálózat keretében és a térségi tanácsadó (Széchenyi programiroda munkatársa) gyakornoki programja irányító hatóságnál, közremüködő szervezetnél;

- a hálózati tevékenység ellenőrzése kevesebb adminisztrációs terhet jelentsen több helyszíni ellenőrzéssel;

- az informatikai adatbázis-kezelésre hatékonyabb szoftver-fejlesztés ráépítése;

- „Szakértői pool”-ok - pályázatírás, projektmenedzsment, közbeszerzés - és a Hálózat munkatársainak feladat-és felelősségi kör lehatárolása; 
- pályázatértékelők felkészítésébe a Széchenyi programiroda munkatársak bevonása;

- a közremúködő szervezet munkatársaival szabályozott módon megvalósuló közvetítői tevékenység a projektmegvalósítás időszakában: általuk felkészítve megrendezett térségi tájékoztató rendezvények az érintett célcsoport részére; kedvezményezett módosítási szándékának közvetítése és a szabályos bonyolítás elősegítése;

- rendszeres helyszíni látogatások bevezetése a közremüködő szervezet monitoring munkáját elősegítendő, ehhez szakmai felkészítést jelent a helyszíni ellenőrzéseken történő részvétel;

- központosított, felülről lefelé irányuló képzések megvalósítása a közremüködő szervezetek bevonásával;

- integráltabb térségi kommunikációs tevékenység: célcsoporthoz illeszkedő médiafelület kiválasztása és a hirdetéstartalmak előzetes kontrollja a Széchenyi programiroda munkatársai által;

- ún. minta-projektek kiválasztásának feladata a későbbi tervezés és a megfelelő kommunikáció érdekében;

Mindkét interjú alapján jelentős elmozdulás azonosítható az eredeti szándéktól. A második fejlesztési periódus utolsó két évében jelentősen áthelyeződött a hangsúly a közremüködő szervezetek funkciójának megfelelő projektellenőrzésekre. Ez megjelent a fenti hatékonyságjavító intézkedések között, ugyanakkor sajnálatos módon nem a preventív és esetleges probléma-megoldás típusú monitoring látogatások gyakorlata alakult ki, hanem a megvalósult projektek utólagos helyszíni ellenőrzéseivel foglalkoztak a munkatársak. Ez a szerepváltás ugyan jól jött a KSZ költségeket és kapacitásokat kímélő humánerőforrás kihasználásának, de nem szolgálta a szervezet létrehozásának eredeti és leginkább szükséges célját. Az elmúlt két évben az utólagos ellenőrzésekkel elfoglalt munkatársak nem végezték a korábbi program indulásakor oly indokolt és szükséges tájékoztató munkát a lehetséges projekttartalmakról az operatív programok kialakításához, különös tekintettel a TOP tartalmára. Elsikkadt a korábban jellemző erős térségi kapcsolódás, ami köszönhető egyrészt a korábbi részben bemutatott területfejlesztés szintjeinek átalakulásának és a térségi területfejlesztési társaságok megszüntetésének, de a hálózati irányítás 
hangsúlyváltásának is. A tematikus képzések, felkészítések kifejezetten egy EFOP programra, a „Fiatalok vállalkozóvá válásának elősegítésére” koncentrálnak, mely a non-profit tanácsadó jelleget nem a támogatáspolitikai intézményi szereplők és a támogatottak közötti kapcsolat hatékonyság-központú megközelítésében látja, hanem kifejezetten egy program célcsoportjának mentorálásában, így létjogosultsága bizonytalan.

A non-profit tanácsadó program megtartása csak abban az esetben indokolt, ha az eredeti, a szakirodalom által is megerősített célokat szolgálja, erősebb térségi beágyazottsággal - akár a járási Kormányablakok szolgáltatásainak részeként -, erősebb tájékoztatási, monitorozási, visszajelzési inputok adva a 2014-2020-as periódus programjainak. Nem mellőzhető az a tény sem, hogy az elmúlt évtizedben kiépült szerteágazó pályázatíró/tanácsadó-szolgáltatási szféra csaknem kiváltja a feladatokat. Esetükben azonban sosem mellőzhető a profitorientáltság, melynek gyakorta tapasztalt jelenségei az információmonopólium és járadékvadászat, valamint az elnyert támogatás mértékével arányos sikerdíj okozta projekt-tartalom torzulások.

\subsection{Konklúzió, javaslatok}

Teszler a teljes program-és projektciklust átívelő rendszert-támogató modell megoldásaként egy országos lefedettségü, a célcsoportok számára ingyenesen rendelkezésre álló, megfelelő informatikai háttérbázissal rendelkező hálózat kialakítására tett javaslatot. Ez a második Nemzeti Fejlesztési Terv Kistérségi Hálózatával megvalósult, jelentős előrelépést téve a szolgáltató közigazgatás útján. Annak érdekében azonban, hogy ez az eszköz megtestesítse azt a disszeminációs tudás-transzfer hálózatot, mely a harmadik fejlesztési terv részeként a hatékonyságot szolgálhatja, szükséges a teljes intézményrendszer integránsabb részévé tenni, egyenlő partnereként az irányító hatóságoknak, közremüködő szervezeteknek, leszabályozott keretek között elöírni és megvalósítani a gyakorlatban kialakult folyamatokat. Az illusztratív, szakirodalmi szinergiát is vizsgáló esettanulmány a második hipotézis mindhárom alpontját bizonyítja, melyek eltérő mértékben már a korábbi programozás periódusban is érvényesültek, vagy a javaslatok alapján potenciálisan a 2014-2020-as időszak megvalósításának kialakításában szolgálhatják a hatékony felhasználást. 


\section{FEJEZET}

\section{HATÉKONYSÁG-KÖZPONTÚ ESETLEÍRÁSOK A HAZAI TÁMOGATÁS- FELHASZNÁLÁS TÍZ ÉVÉBÖL}

A fejezetben módszertanilag a projektszintü esetleírások eszközével élek, melyek többségében - a hazai megvalósítás több mint egy évtizedes, három programozási időszak gyakorlatából származnak. Az teljes programozásra jellemző képet adnak, általános problémát azonosítanak, és intézményi szinten adaptálható javaslatok fogalmazhatóak meg az értekezés második hipotézisének bizonyítása érdekében.

\subsection{Tartartalék-felhasználás szabályozásának változása a racionalitás jegyében}

A kiválasztott téma azért fontos, mert jól szemlélteti azt a fejlődési ívet, amit a hazai szabályozás e tekintetben bejárt, nem csak tartalmi értelemben, hanem intézmény müködési változásokhoz köthetően az első két programozási periódusban látható megoldások alapján. Míg az I. NFT időszakában - hasonlóan a jelenlegi működéshez - az adott irányító hatóságok miniszterelnöki hivatali koordinációval, de szaktárcákhoz rendelten müködtek, a tartalék-felhasználás szabályozási megoldásai teljesen heterogén és szélsőséges megoldásokat tartalmaztak az eltérö jogszabály értelmezések és a koordináció korlátozottsága okán. Egyes programok esetében tervezhető és „viszonylag” szabadon felhasználható részét képezték a projektnek, míg más operatív programok esetében a tervezhetősége sem volt engedélyezett, vagy felhasználásában jelentős megkötésekkel szembesültek a projektgazdák. Például egy iskola felújítás esetében a közbeszerzésből eredő költségmegtakarítást, mint projekttartalékot nem lehetett felhasználni a korábban nem tervezett, de indokolt iskolakerítés cseréjére. A 2006-ban a Nemzeti Fejlesztési Ügynökség létrehozásával elkezdődött központosítás egyik jelentős eredménye volt, hogy az ún. nevezetett „back office” szolgáltatásokat, mint például a jogi és pénzügyi területek koordinációja, elvonta az egyes irányító hatóságoktól és a teljes 2007-2013-as időszakra azonos, egységes szabályozássá alakította. A kezdeti nehézségeket 
követően e téren jelentős eredményt ért el a folyamatok egységesítése és a jogszabály-értelmezések területén is, beleértve a példaként említett tartalékfelhasználást. Ez rugalmasabb, a jogszabályok értelmezésében tágabb (és ésszerübb) projektmegvalósítást eredményezett. Erre látványos példa az a jászfényszarui ipari parki fejlesztés, melynek keretében nemcsak a vállalkozói ház és további területelőkészítés tudott megvalósulni, hanem az alábbi képen látható, a tartalékból felhasználható újabb, funkcionalitásában többletet és komplexebb megvalósítást eredményező $500 \mathrm{~nm}$ alapterületü csarnok megépítése. A multifunkciós csarnok igény esetén két részre osztható, alaprajzi elrendezése és a kialakítása lehetővé teszi, hogy párhuzamosan több típusú tevékenységhez szolgáljon helyszínül, úgy mint bemutatóterem, rendezvény és képzés. Az intézményrendszeri rugalmasság, valamint a támogatott proaktív magatartásának büszke eredménye ez az esetpélda, mely különösen értékes a program megvalósítás utolsó éveiben, hiszen a fel nem használt források újbóli kihelyezésére nincs/nem lett volna idő. A csarnok méltó avatását jelentette 2016. áprilisban a Thyssen-Krupp 33 milliárd Forintos zöld mezős beruházása a városban.
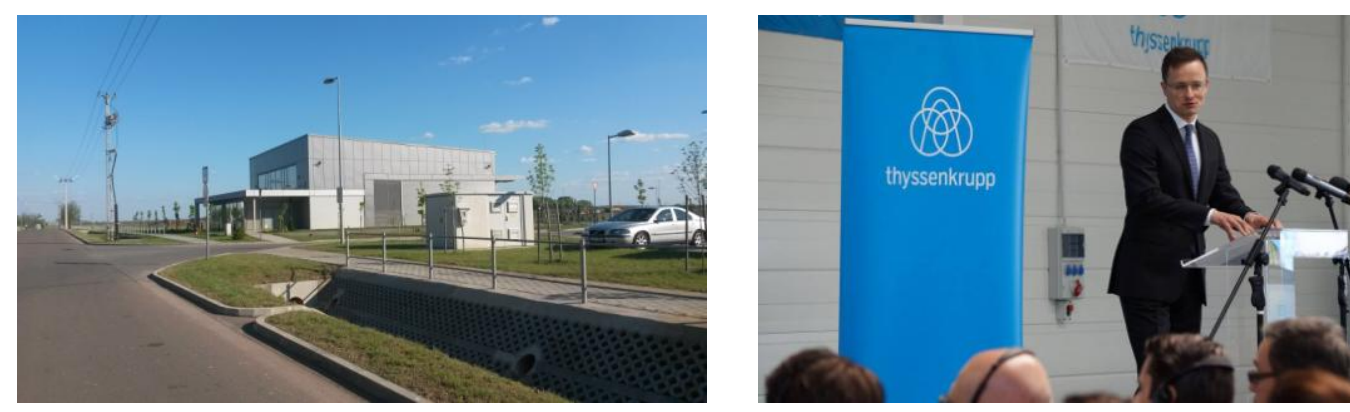

1. kép: Multifunkciós csarnok „használat közben” a jászfényszarui ipari parkban

\section{2 ÁFA, mint állami direktfinanszírozás: a nettó befizetők jogos kritikája}

$\mathrm{Az}$ esetleírás a második részben bemutatott nettó befizető és nettó haszonélvező tagállamok éles vitáinak tárgyát képező ÁFA-elszámolhatóság kérdését járja körbe. A nettó befizető tagállamok egyszerü költségvetési direkt-transzfernek tekintik az adótételt és a 2014-2020 programozási periódusra az elszámolhatóság eltörlését kívánták annak érdekében, hogy az így megtakarított összegek is valódi kihelyezést, fejlesztést tudjanak jelenteni. A képviselt reformjavaslat súlya érzékeltethetővé válik egy hazai valós példán 
keresztül. Egy középvállalat a Társadalmi Megújulás Operatív Program (továbbiakban TÁMOP) keretében „Munkahelyi képzések támogatása középvállalkozások számára a konvergencia régiókban” címü felhívásra pályázatot nyújtott be és közel 9 millió Forint 100\%-os támogatást nyert el dolgozói egészségfejlesztésére „Egészségre nevelő és szemléletformáló életmód programok - lokális színterek” kiírás keretében. Erre a célra gazdasági társaságok részére kettő milliárd Forint állt rendelkezésre országosan, a meghirdetett felhívásra 2557 db pályázat érkezett be 23,8 Mrd Forint forrásigénnyel, jóllehet ebben a darabszámban a non-profit szféra 3 Mrd-os keretre beadott ugyanezen pályázatai is szerepelnek -, ezért a meghirdetést követő néhány nap múlva a kiírást a Nemzeti Fejlesztési Ügynökség felfüggesztette. A cég számára - tekintettel arra, hogy tevékenységével nem szorosan összefüggő tevékenységekről volt szó, - az ÁFA szabályok értelmében ez az adó nem visszaigényelhető, így bruttó módon számolhatott el a projektben, vagyis a támogatás terhére elszámolható volt az ÁFA költsége. Ez az elnyert támogatást és a programra fordítható összeget közel 27\%-kal csökkentette, csak néhány képzés és szolgáltatás esetében állt fenn tárgyi vagy alanyi ÁFA-mentesség. A támogatásból elszámolt, a terhére befizetett ÁFA összege a projekt végelszámolásánál 1.270.297 Forintot jelentett, vagyis a támogatás 15\%-át. További forrásvesztést jelentett az a jogszabályi kötelezettség, hogy a külső szolgáltatótól igénybe vett szolgáltatások közül azok, melyeket közvetlenül a dolgozók számára vettek igénybe (pl. tréningek, úszásoktatás, egészségügyi szürés, stb.) az 1995. évi CXVII. tv. 70. § (1) értelmében „egyes meghatározott juttatásnak” minősültek, így az adott költségnél a céget terhelte a juttatás bruttó értékének 1,19-szeresére vetített $16 \%$ SZJA és 27\% EHO. A Közremüködő Szervezet állásfoglalása alapján a költségekhez tartozó járulékok szintén elszámolhatóak a projekt terhére. Ez a példaként kiemelt projekt esetében az úszótanfolyam, túrák, kerékpártúrák, kenutúra, közérzetjavító masszázs, főzőtanfolyam, dohányzás-leszoktatás, fogápolási és drog-prevenciós előadások, egészségnapok programjait érintette, összesen 1.449 .000 Ft.- értékben. A megbízási szerződés keretében, de bérjuttatással megvalósított programok esetében a bért terhelő munkáltatói járulékok 337.472 Forint költségterhet jelentettek a programban. Ez a három, az állami költségvetésbe visszafizetett tétel összesen 3.056.769 Forint volt, a megítélt és elnyert támogatás 35 százaléka. Ezzel az állami büdzsébe visszafizetett támogatással egyharmaddal több személyt - programnyelven indikátort - lehetett volna elérni, hiszen a pályázói aktivitás alapján lettek volna további potens felhasználók. Így még inkább sajnálatos, hogy a nettó befizető tagállamok reformjavaslata e tárgyban nem épült be a gyakorlatba a 2014-2020 közötti időszak felhasználásában sem. A programok 
hatékonysága szempontjából a reformjavaslat létjogosultsága elvitathatatlan volt a támogatások állami költségvetési direkttranszferré válásának elkerülése érdekében, jóllehet a nettó haszonélvező országok sikerként jellemezték javaslatuk „életben maradását”. A témában kiemelten érintett az ESZA alap programjai, ahol az ún. bruttó módon elszámoló civil szféra, és sok esetben önkormányzati szektor, valamint a kiemelt projektek intézményi szereplői, de a fenti példa alapján egyes fejlesztések esetében a gazdasági szektor is az ÁFA-val (és jellemzően bérköltségeket is) növelt projektköltséggel számol el. Ez alapján kijelenthető a teljes alap vonatkozásában, hogy hazánkban legalább 20\% -os mértékủ fejlesztési forrás kivonása történt meg az Európai Szociális Alap esetében. A kohéziós források infrastrukturális alapjainál is számottevő, de e terjedelmi korlátok között kevésbé egzakt módon határozható meg az állami és önkormányzati infrastrukturális projektek bruttó ÁFA-tartalma, mely a költségvetés adóbevételeit közvetlenül gyarapította a kihelyezhető támogatások rovására.

\subsection{Nyílt pályázati eljárásrend a három programozási periódusban}

Az utolsó esetleírások a hazai projektszelekciót a nemzetközi mérések tükrében vizsgálják, és igazolják vissza, melynek tanulsága beépíthető javaslatot jelenthet az új programozási periódus első harmadában.

Az első, tört-időszaki fejlesztési időszak két eljárásrendje - az egyfordulós nyílt, valamint a kiemelt eljárásrend - egyszerüséget sugallt, ugyanakkor ezen belül jelentek meg a közremúködő szervezetek által eltérő módon kezelt gyakorlatok. A 2007-2013-as programozási periódus projekt kiválasztási eljárásrendje már sokszínübben alakult, ennek összetettségét mutatja be a következő ábra (8. ábra)

8.ábra: A 2007-2013-as programozási periódus projekt kiválasztási eljárásrendje 


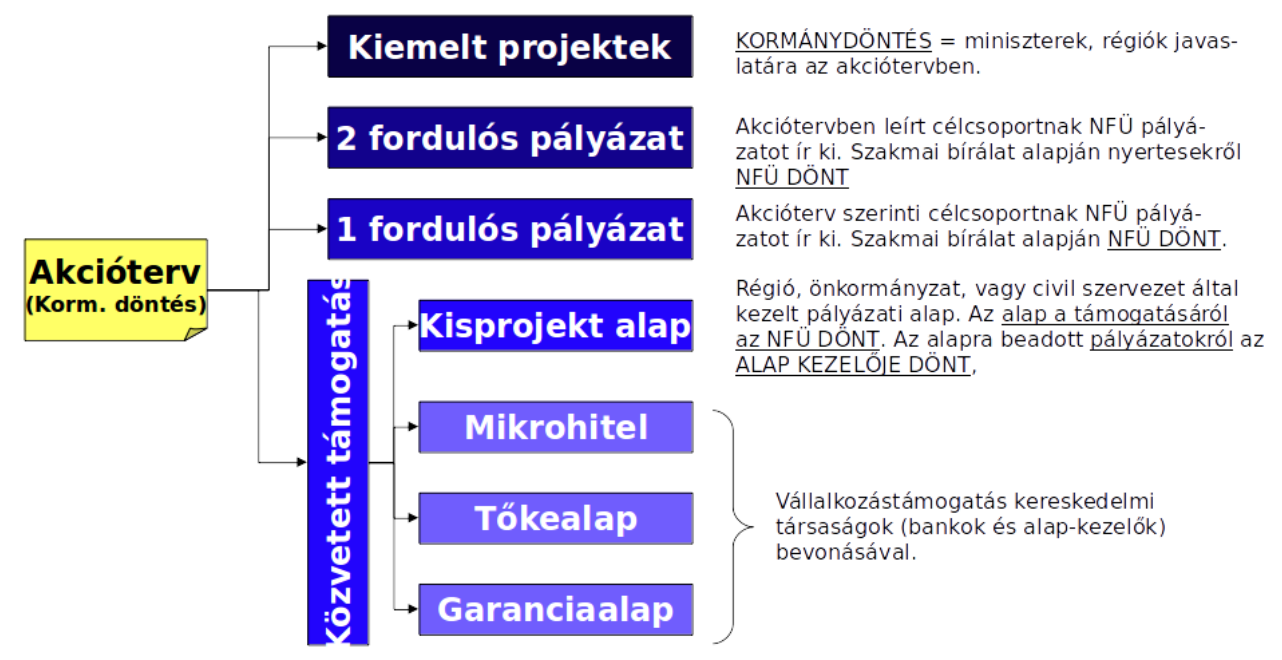

Forrás: Megakom Stratégiai Tanácsadó Iroda, Előadás az Észak-Alföldi Regionális Fejlesztési Non-profit Kft. munkatársai részére, 2007.09.24.

Bár valamennyi eljárásrendnél azonosíthatóak típushibák, a legnagyobb számban a nyílt (két-és egyfordulós) eljárással kiírt felhívásokra adtak be pályázatokat, mely a verseny-központú megközelítésben a beérkezési sorrend szerinti bírálatot vagy adott időszakban pontszám és beadás szerinti bírálatot jelentette. Az eljárásrendre vonatkozó alábbi esetleírások az eljárásrend olyan metamorfózisát mutatja be, mely szélsőséges eredményt hozott a minőségi kiválasztási szándékkal választott megoldásban. Előbbi esetében kísérőjelenség a közel egy évtizedes tapasztalatként jelentkező, a támogatások felhasználását kísérő túlszabályozottság, és az ehhez társuló ún. „szabályossági görcs” (Balás [2013]), melyen keresztül olykor elvész a józan ítélőképesség. Ez látható az alábbi példából, mely az egyik legelmaradottabb régió KKV-szektor pályázati tapasztalataiból származik. A Társadalmi Megújulás Operatív Program (továbbiakban TÁMOP) keretében „Munkahelyi képzések támogatása középvállalkozások számára a konvergencia régiókban" címü felhívásra egy közel 250 föt foglalkoztató, 21 éve müködő, magyar családi tulajdonban álló, exportra termelő beszállító cég is pályázatot nyújtott be. A közel 150 dolgozójának két éven át 21 szakmai és nyelvi képzését lehetővé tévő pályázat formai elutasítását 
az eredményezte, hogy a pályázatot (egy CD adathordozót és egyoldalas papír alapú nyilatkozatot) a vállalkozás ajánlott küldeményként és nem csomagként postázott a Támogató részére - ahogyan az útmutatóban szerepelt -, jóllehet párhuzamos kiírások A TÁMOP-ban ugyanekkor valamennyi feladási opciót lehetővé tették. A példa jól szemlélteti, hogy bár a célok megfelelőek, a szabályszerűség kifogástalan volt - ezt bizonyítja, hogy közremüködő szervezeti szintü és irányító hatósági felülvizsgálat is történt az ügyben, mely nem módosította a döntést - a megvalósítás mikéntjében elveszett 150 fö foglalkoztatott közel háromszáz képzés/fö fajlagos eredményt hozó két évi nyelvi és szakmai képzése.

A másik példa azt a hazai gyakorlatot mutatja be, mely az intézményi és szabályozási környezet eredményeként gyakorlattá vált a pályázatírók munkájában. Egy beadássorrendű döntést eredményező nyílt pályázati felhívásban az idő rövidségére való tekintettel csupán az elképzelés váza került beadásra, és a hiánypótlás szakaszára maradt a valódi tartalmi értékek benyújtása. Ez jelentett projekt-típustól függően önéletrajzokat, építési terveket és költségvetést, árajánlatokat, együttműködési megállapodásokat. Aki a kiírás eredeti szándéka szerint jól elkészített projektet kívánt beadni, de ezt - a munka természetes hozadékaként - az első beadási naphoz képest néhány napos késedelemben tette, ugyan szakmailag jobb tartalmú anyagot adott be, de forráshiányos elutasításban részesült. Ennek szélsőséges esete a civil szektort érintő, az ÁFA-elszámolhatóság esetében példaként említett konstrukció volt, ahol már az első napon beadott pályamüvek közül is csak az részesülhetett támogatásban, amely futárpostával és nem normál postai elsőbbségi feladványként került a közremüködő szervezethez. Ez számos ágazati és regionális program keretében tapasztalható volt. A disszertáció nemzetközi mérési gyakorlatai között szereplő holland mérési jelentésekben megjelenő javaslatot itthon is felülvizsgálni javasolt (EPRC[2014]p19 és Rekenkamer [2014]). A holland jelentés szerint a projektszelekció versenyszempontú megközelítése akkor javasolt, ha az a hatékonyság/eredményesség érdekében történik, és nem egyszerüen a beérkezési sorrend alapján történő döntést eredményezi. A hazai 2014-2020-as operatív programok ex-ante értékeléseiben fellelhető ilyen irányú szándék, különösen a TOP fejlesztéseit érintően, és a kutatási munkám utolsó, kontrafaktuális vizsgálaton alapuló elemzésemben is visszaigazolódik a megállapítás. A közszféra, mint projektgazda és közszolgáltatások egyenletes színvonalú, költséghatékony és racionális biztosítása érdekében a kiválasztásos projektcsatornák, vagy a szaktárca által koordinált, de iteratív megvalósítás szolgálja a hatékonyságot, és ennek következtében az eredményességet és 
hatásosságot is. Nagy Sándor Gyula a 2008-ban megvédett doktori disszertációjában bemutat egy 2000-2006-os portugál programozási gyakorlatot (Nagy [2008] p137), melyben az önkormányzati projektkiválasztás a Regionális Operatív Programok keretében egy LAU I-es szinten települések társulásaiként kimunkált beruházási programot készítettek, amely önálló intézkedésként jelent meg a ROP-okban. Ehhez hasonló eljárásrendről adott tájékoztatást kvalitatív mélyinterjú keretében dr. Debreczeni Ferenc, az Észak-Alföldi Regionális Fejlesztési Ügynökség igazgatója, akinek Franciaországban a 2000-2006-os programozási időszakban mutattak be számára ennek megfelelő projekt-kiválasztási gyakorlatot. A finanszírozás hozzárendelése program-, és nem projektalapon történt. Ez egy adott közösség, fejlesztési célcsoport költségkeretek közötti tervezését, „beosztó”, hosszútávra tervező megvalósítását eredményezi, melynek előfeltétele a partnerség és szubszidiaritás. A disszertáció következő részében egy ennek megfelelő eljárásrend kontrafaktuális vizsgálatát végzem el és elemzem.

\subsection{Konklúzió}

A tartalék-felhasználás példája azt mutatja, hogy a különböző irányító hatóságoknál eltérően értelmezett és ennek megfelelően nem egységesen alkalmazott uniós aqui-t a központi egységesítés jegyében a lehetséges mértékig felhasználóbarát megvalósítást és ennek megfelelően hatékony forráskihelyezést alakított ki az intézményrendszer (mely gyakorlat kívánatos a 2014-2020-as időszakra a szaktárcákhoz visszarendeződött irányító hatóságokkal is). Azonban analógia vonható nemzetközi megközelítésben is; vagyis indokolt lenne, hogy az egyes tagállamok között (például az ismét erös érdekképviseleti tevékenységet folytató Visegrád Négyek keretében) uniós végrehajtási szabályozások együttes értelmezése, és az esetleges kötelezettségszegési eljárások esetében is erösebb, közös érdekképviseletet alkotva kellene nemcsak szakpolitikai szinten, de a már-már operatív szinten is egyeztetéseket folytatni az ésszerű támogatásfelhasználás érdekében. Az idén elszámolási zárás szakaszába lépett 2007-2013-as támogatási periódusban számos esetben hatékonyabb, és a tagállamok számára kedvezőbb kimeneteket eredményezhetett volna más tagállamokban alkalmazott gyakorlatok összehangolásával, pl. az önkormányzati projekt saját erő, mint tagállami önerő kérdésében is. A további esetpéldák tipikusan azt a tématerületet adják, ahol más tagállamok végrehajtási tevékenységét szorosabb együttmüködések keretében lenne 
szükséges vizsgálni, ez az elöre egyeztetett módszer a későbbi bizottsági ellenérzések esetleges megjelenésekor is erösebb érdekképviseletet tud jelenteni.

A rövid esetpéldák a legitim partnerséget egy nemzetközi színtéren történö értelmezés feltételeként és jövőbeni javaslatával kiegészítve járulnak hozzá a disszertáció második hipotézisének valamennyi alpontja bizonyításához.

III.RÉSZ

KONTRAFAKTUÁLIS MIKROÖKONÓMIAI ÖSSZEHASONLÍTÓ VIZSGÁLAT PROGRAM-, ÉS PROJEKTSZINTEN

\section{FEJEZET}

KUTATÁSI KERETEK, FELTÉTELEK MEGHATÁROZÁSA

\subsection{Kutatási probléma megfogalmazása}

Ebben a részben a $\mathrm{H} 2 \mathrm{~b}$ hipotézist kívánom elsősorban bizonyítani, mely szerint a programtervezés, projektgenerálás, projektkiválasztás során megjelenő adekvát szubszidiaritás és legitim partnerség javítja a hatékony felhasználást. A következő pontban ábrázolt nemzetközi módszertan első hazai adaptációjával hasonlítok össze két változót. A 2007-2013-as tervezési periódusban az Észak-Alföldi Regionális Operatív Programon belül az „Oktatási-nevelési, egészségügyi, szociális és közösségi intézményfejlesztés” konstrukció keretében a közremüködő szervezet egy új eljárásrendet kívánt bevezetni, az alulról, önkormányzati, kistérségi szintről építkező térségi fejlesztési stratégiákra épülő projektlisták kiemelt eljárásrendjét. Ennek programtervezési, projektgenerálási és projekt-kiválasztási szakaszát az Észak-Alföldi Regionális Fejlesztési Ügynökség legitim módon lefolytatta 2007. év második félévére. Az Irányító Hatóság az eredmények ellenére nyílt, szabad versenyt képviselő pályázati rendszerü hét éves eljárásrend mellett döntött, és így valósította meg a hét éves programot. 
Kutatási munkámban a 2007-ben készült projektlisták és az n+2 év végére megvalósult beruházások összevetését kívánom megvalósítani azzal a hipotézissel, hogy a ténylegesen - megvalósult vagyis az adekvát szubszidiaritást és legitim partnerséget nélkülöző programozás, projektgenerálás és projektkiválasztás rendszerével - fejlesztések kevésbé hatékonyak, mint az érintett térségi szereplők bevonásával, konszenzusával létrehozott projektek, és térségi kimenetek.

A vizsgálatban mindkét szinten vizsgálni tudom a hatékonyságra megállapított jellemzők érvényesülését az alábbiak szerint:

Projekt szinten:

- egy adott fejlesztés megvalósítása miért szenvedett késedelmet (a programozási időszak végéhez közel eső megvalósítás időbeni elhúzódása abszorpciós veszélyeket hordoz, a megvalósítás során keletkező egyenetlen munkahullámok pedig intézményi kapacitásproblémákat, annak következtében az egyes projekteknél döntési és finanszírozási késedelmet, többlet-költségeket és bizonytalansági „humán-terhet”);

- a tervezett költségvetéshez képest hogyan alakult a tényleges megvalósítás során jelentkező forrásigény (ezen belül az önerő és támogatás mértékének/arányának alakulása);

- milyen járulékos költségek terhelték a fejlesztést (ezek létének és mértékének vizsgálata az intézményrendszer müködési problémáira, és jogszabályi előfeltételek túlzó vagy nem megfelelő kialakítására reflektál(hat));

- a tervezett tartalmon túl milyen többlet-tevékenységek valósultak meg kötelező vagy opcionális jelleggel.

Program szinten az alábbi kritériumok fémjelzik a hatékonyságot:

- előre-jelezhetőség

- rugalmasság

- jövő-orientált tervezés

- folyamat-közbeni monitorozás és értékelés 
- területi szinergia

- visszacsatolás lehetősége

Az Európai Bizottság Regionális Politikai Főigazgatóságának elismerésével müködő, a második fejezetben bemutatott EVALSED módszertani ajánlásai között szerepel annak a szempontnak a vizsgálata, hogy más eszközökkel jobb eredményt lehetett volna elérni. Ezt a kérdést e kontrafaktuális vizsgálatomban körbejárom, hiszen programszinten az is megállapíthatóvá válik, hogy a tervszinten maradt, eredeti projektszelekciós eszközzel jobb eredményt lehetett volna-e elérni.

1.2 Nemzetközi módszertani alapok áttekintése és a hazai adaptáció azonosítása

A fejezeti kapcsolódás miatt itt szeretném kifejezni a Szent-Györgyi Albert díjas Dr. Habil Hrubos Ildikónak, a Budapesti Corvinus Egyetem Társadalomtudományi Kar Szociológia és Társadalompolitikai Intézet professzor emeritájának segítő közremüködését a rendhagyó kutatási megoldás kiválasztásában és kialakításában.

$\mathrm{Az}$ értekezésem első részében mutattam be azt a német tagállami mikro-ökonómiai tényellentétes vizsgálatot, mely mérési gyakorlatot Olaszország és Csehország is alkalmazott a 2007-13-as időszakban, előbbi az ERFA finanszírozású ROP-okban, Csehország a humánerőforrásokat támogató ESZA ágazati programjában (Potluka, Bruha[2014] és Valenza et al [2011]). Ezeknek a módszereknek a hazai adaptációját valósítom meg kutatásomban, jóllehet a módszerem egy speciális Difference in difference (továbbiakban DID-módszer), mert összehasonlítja a kiemelt eljárás szerinti kimenetet (ez ugyan terv szinten maradt, de pontos projekttartalommal) a tényleges kimentettel, ami a nyílt projektszelekciós eljárás eredménye lett. Sajnos a klasszikus DID eljárás azon része esetemben kizárható, hogy a tervezett fejlesztések az uniós forrás nélkül is, saját forrásból megvalósultak volna, így nem a klasszikus támogatott-nem támogatott vizsgálati módszer kerül alkalmazásra.

Nagy Sándor Gyula a 2008-ban megvédett doktori disszertációjában bemutat egy 2000-2006-os portugál programozási gyakorlatot (Nagy [2008] p137), melyben az önkormányzati projektkiválasztás a Regionális Operatív Programok keretében egy LAU I-es szinten települések társulásaiként kimunkált beruházási programot készítettek, amely önálló intézkedésként jelent meg a ROP-okban. A finanszírozás 
hozzárendelése program-, és nem projektalapon történt. Ez a példa adaptálódott a 2007-es ÉAOP-4.2.1 tervezési szintjén, bár a kettő közötti kapcsolat - az ÉARFÜ vezetőjével történt interjú alapján - nem volt kimutatható.

A Hétfa Kutatási Intézet Kohéziós területi jelentése (Balás [2013] pp202-203.) megemlít egy szlovák példát, egy projektcsomagok néven megvalósított eljárásrendi gyakorlatot. Ez Magyarországon a megvalósult két programozási időszakban egyetlen operatív programban sem került alkalmazásra, és tervezési szinten is csak ebben az Észak-Alföldi, az egyik leghátrányosabb régióban jelent meg, (utólag megállapítva) kísérleti stádiumban maradva.

Vizsgálatom módszere a fentiek alapján elmélet-alapú elemzést jelent, mert nem csak a két vizsgált állapot közötti különbséget mutatom ki, hanem a hogyan kérdésre kapunk választ. Ennek hipotézise megítélésem szerint az adekvát partnerséget és szubszidiaritást nélkülöző eljárással lefolytatott tényleges projektszelekció, valamint a további, nem hatékonyság-orientált megvalósítás hozadéka.

A különlegessége, hogy nem a klasszikus terv-tény összehasonlítás, jóllehet a tárgya azonos a két vizsgált időpontban. A szakirodalom alapján (Babbie [2003] p.118) kutatásom longitudinálisnak tekinthető, mert egy teljes programozási időszakon keresztül történt intézményi és megvalósítási eseményeket ölel fel, a teljes $n+2$ időszak figyelembe vételével. A vizsgálat ezen belül panelvizsgálat kategóriájába tartozik (Babbie [2003]p.119), mert a vizsgálat tárgya mindig azonos: adott település adott humán infrastrukturális objektuma (iskola, egészségház, házi orvosi rendelö, közösségi ház). A vizsgálat típusának oka a nyomon követés szándéka, mely szerint a terv szerinti projektszelekciós eljárással megvalósítani kívánt beruházások helyett a nyílt pályázati rendszerben megvalósított projektszelekció milyen különbségeket eredményezett és milyen okok álltak a különbségek hátterében. A két eljárásrend szerinti megoldásbeli különbségek vizsgálják az intézményi oldali megvalósítási gyakorlat, és a jogszabályi keretrendszer különbözöségét, valamint - jogosultsági szempontból azonos önkormányzati - kedvezményezetti oldal két eljárásrendben azonosítható pályázati attitüdjeit, különbségeit.

A kutatás ugyanakkor hordozza a keresztmetszeti vizsgálatok egyes sajátosságait is, a két - a programozás szempontjából meghatározó - időpontban végzett összehasonlító elemzés módszere. 
A kontrollcsoportos vizsgálat szükségességét F.J.Roethlisberger és W.J. Dickson vizsgálatsorozata bizonyította a társadalomtudományokban (Roethlisberger Dickson [1939]), ez alapján két kistérséget választok ki, két-két 2007-es és 2015-ös adatsort hasonlítok össze.

Ugyan a kutatásom nem tekinthető kísérletnek, azonban ez a kvázi-illesztés módszere a kísérletek kategóriájába tartozik, és erre vonatkozó érvényességi kritériumokat a szakirodalom alapján megvizsgáltam, és alávetettem módszerem az alábbiak szerint (Campbell - Stanley [1963]: és Campbell - Cook [1979]):

1. Történelmi érvénytelenség elkerülése érdekében a két adatfelvételi időpont között, a pályázati rendszeren kívül, de a kimenetelt befolyásoló tényezők (pl. helyhatósági választások 2010-ben, jogszabályi változások) megismerésére a vizsgálat kitér oly módon, hogy a 2015-ös adatok kvalitatív értékelése során rákérdezek a változás okának azonosíthatóságára, ez a jogszabályi és helyhatósági választások okozta érvénytelenséget kiolthatja.

2. Az adatok mérésének két időpontja közötti " érés" problémája: azáltal, hogy a vizsgálat tárgya nem természetes személy, hanem infrastrukturális beavatkozási pontok (pl. iskola, házi orvosi rendelő) az adatok egzakt módon mérhetőek az EMIR adatai alapján.

3. A két időpontban keletkező adatok ugyan eltérő adatbázisból jönnek létre, de mindkettő autentikus, legitim és összevethető adatsorokat képez: a 2015-ös adatok esetében a második pontban nevesített informatikai adatbázis, míg a 2007-es adatfelvétel során az Észak-Alföldi Regionális Fejlesztési Tanács által jóváhagyott projektlisták adják a kiindulási alapot.

4. Kísérleti "elhalálozás" jelen kutatás esetében valós jelenség lehet, az alanyok "kilépése" a 2015-ös kimenetek egyik valós alternatívája. A tervprojekt után a beruházás megvalósulásának elmaradása vizsgálandó, mely adódhat jogosultsági okokból (pl. minimális projektméret növekedése, vagy bizonyos településméretek kizárása a tényleges pályázás során), vagy más támogatási alap nyújtotta versenyhelyzetből. Ennek vizsgálata szintén a kvalitatív mélyinterjú keretében azonosíthatóvá válik. 
5. A kiegyenlítő versengés problematikája kutatásomban nem fordul elő, mert a versengés a forrásokért mindkét eljárás során érvényesült a szereplőknél, csupán eltérő eljárásrendi körülmények között valósult meg.

6. A demoralizálódási érvénytelenségi jelenség szintén kizárható a folyamatból, mert az első pontban említett helyhatósági választások rákényszerítik az eredményekre a térségi szereplőket a fejlesztésekre, ugyanakkor az valós félelem, hogy a nem megfelelő felhasználás kiábrándította a projektgazdákat, pályázókat. Ez utóbbi érvénytelenségi kérdést az első pontban nevesített alkalommal, a kvalitatív elemzés során szintén figyelembe veszem.

\section{3 Kutatás tárgyának kijelölése}

Az Észak-Alföldi Regionális Fejlesztési Ügynökség minden kistérségben felkérte a kistérségi tanácsok elnökeit és tagjait, hogy a regionális akcióterv ÉAOP- 4.2.1. „Oktatási-nevelési, egészségügyi, szociális és közösségi intézményfejlesztés” konstrukciójához kapcsolódóan készítse el hét évre a kistérségnek a humán közszolgáltatások fejlesztésére vonatkozó tervét. Ez az alábbi dokumentumokból állt:

- helyzetfeltárás, amelyben a kistérség bemutatja, hogy milyen egyenőtlenségek, hiányosságok vannak az oktatás, egészségügy, szociális ellátás és a közösségi infrastruktúra területén, milyen az ellátás színvonala, szerkezete, milyen a kistérség demográfiai helyzete;

- stratégia, amelyben a kistérség bemutatja, hogy melyek a fó megoldandó feladatok, és megindokolja, hogy a tervezett fejlesztések miként járulnak hozzá a kistérségi egyenletes színvonalú ellátás megteremtéséhez, a humán közszolgáltatások optimális térségi szerkezetének kialakulásához;

- projektlista, amely tartalmazza a stratégiában felvázolt feladatok teljesítéséhez szükséges fejlesztések bemutatását (projektgazda, leírás, tervezett költségvetés, időütemezés stb.).

A konstrukció keretében kistérségenként meghatározásra került egy hétéves indikatív tervezési forráskeret, amely pénzügyi keretül szolgált a kistérségi tervezés számára. A forráskeret meghatározása KSH mutatókból képzett komplex indikátorrendszer 
segítségével történt. Ebben az indikátorrendszerben megjelentek azok az indikátorok, amelyek a kistérségenként elvégzendő feladatok volumenére utalnak, így figyelembe lett véve a fejlesztendő intézmények és feladatellátó-helyek száma, a kihasználtság mértéke, az igénybevevő lakosság számának várható jövőbeni alakulása (pl. oktatási infrastruktúra esetén a gyereklétszám változása), a kistérségen belül a települések száma, a kistérség településeinek lakosságszáma.

A kistérségi tervezési munka célja az volt, hogy az egyeztetések során kistérségi, illetve mikrotérségi funkciókban gondolkodva, kistérségi konszenzussal tegyenek javaslatot az elkövetkező évek fejlesztési forrásainak felhasználására. Ez komoly együttmüködést, és összefogást igényelt a kistérséget alkotó önkormányzatok részéről, a kistérségi vagy mikrotérségi érdekek teljesülése érdekében számos esetben saját, települési érdekek feladását kívánta. Egyben magában hordozta a mikrotérségi összefogás és közös gondolkodás lehetöségét, amely során települési funkciómegosztással lehetett javaslatot tenni a közös fejlesztésekre. A helyzetfeltárást és stratégiai indoklást is tartalmazó projektlistát az országos tervezési folyamatokhoz és határidőkhöz igazodva 2007. február 20-ig kellett eljuttatni az Ügynökséghez a kistérségi társulási tanács elfogadó határozatával, ami biztosítéka és legitimációja volt a kistérségi konszenzusnak. A teljes eljárásrend, a Regionális Fejlesztési Tanácsok határozatai, a 28 térség adatsorai, helyzetértékelései és stratégiával alátámasztott projekt-adatbázisa a elektronikus adathordozón az értekezés függelékében rendelkezésre áll.

Az összehasonlító vizsgálat másik adatsorát (az n+2 időszakának zárására utalóan 2015-ös adatsorként említve) ugyanazon humán közszolgáltatási infrastrukturális fejlesztési forrásokból megvalósított települési fejlesztési beruházások képezik, különös tekintettel azokra az infrastruktúrákra, melyek 2007-ben nevesítésre kerültek.

A beruházások tárgyát a nyilvánosan hozzáférhető elektronikus Egységes Monitoring és Információs Rendszer (továbbiakban EMIR) legitim és kizárólagos adatbázisán keresztül azonosítom, vagyis megnézem, hogy a programozási periódusban ténylegesen megtörtént-e a fejlesztés, a 2007-ben jóváhagyott projektlista szerinti adatokhoz képest milyen különbségekkel a költségvetés, tartalom, ütemezés 
tekintetében. Ezek kvantitív módon mérhető különbségek, míg a mélyebb megértéshez szükség szerint egyedi interjúk történtek a projektgazdákkal.

A két időpillanat azért döntő jelentőségü, mert az első a teljes időszak első éve, amikor az intézményi forrásallokáció kialakulóban van, az Operatív Program szint alatti akciótervi kialakítás tartalmi része történik, ez a tervezés és projektkiválasztás szakasza. A második időpont ugyanazon programozási időszak n+2. évének záró éve, amikor már valamennyi forrás kihelyezésre került, és valamennyi 2007-2013-as időszak humán infrastruktúra projektjének megvalósítása megtörtént.

Valamennyi adat nyilvános és legitim forrásból származik, az első időpont forrásanyagai az Észak-Alföldi Regionális Fejlesztési Tanács jegyzőkönyvben rögzített döntései, a programzárás adatai az Egységes Monitoring és Információs Rendszerből kinyerhető projektadatok, melyek jelzik a projekt méretét, megvalósítás ütemezését, a projekttartalmat.

Kutatásom egy modellezéshez is hasonlítható, amikor hipotézisemet tesztelem, hogy van-e az elméletemre bizonyíték. Az én kutatásom erőssége, hogy ez egy "élő" modellezés, vagyis az első szakasz 2007-ben a térségi projektszelekciós eljárás volt, majd végbement a hét éves programozási periódus is az $n+2$ időszakával, ami a második szakasz "adatfelvételét" adja.

A célom a Max Weber által, a kutatás tevékenységére használt "verstehen" megvalósítása, vagyis a két időpontban látott projekt - pl. egy település általános iskolája - közötti különbség és ezáltal a két kiválasztási eljárás közötti különbség megértése, nem mellőzve a két időpont között végbement, a projektszelekción kívüli intézményi, jogszabályi változásokat is.

Babbie szerint az összehasonlító kutatás során összefüggéseket kell találni a vizsgálat tárgyát leíró nagyszámú részlet között, ez a Weber által ideáltípusok alkotását jelenti (Babbie [2003] p.378). Elemzésemben a két ideáltipikus projektszelekciós eljárás a szubszidiaritással és partnerséggel megvalósított programmegvalósítás, a másik a ténylegesen a 2007-2013-as programozási időszakban alkalmazott nyílt pályázati eljárásrend, mely nem a szubszidiaritás és legitim partnerség, hanem a versenyközpontú és pályázati tanácsadók igénybevételét feltételező megvalósítást jelentette. 
Ez tekinthető beavatkozás nélküli módszernek, és a megismétléssel kezeltem a munkám érvényességi problémáját, vagyis két kistérségben is összehasonlítást végeztem a 2007-es és 2015-ös projektjei között.

A kutatásom erőssége, hogy a szakirodalom definíciója alapján természetesnek nevezhető, vagyis valós környezetben zajlott a 2007-es "előzetes" projektszelekció, és valós környezetben zajlott a 2015-ös utólagos adatvizsgálat is; a tényleges intézményrendszeri szabályozási és müködési környezetben, a valós térségi szereplőkkel. A 2007-ben meghatározott fejlesztési tervekről a döntéseket a térségi szinten legitim szereplők hozták meg (vagyis egy adott iskolafejlesztésről az adott település polgármestere szavazott a Kistérségi Fejlesztési Társulások keretében, aki a képviselő testület felhatalmazását bírta). Később ugyanezen településvezető és testülete dönthetett arról, hogy pályázik-e az iskolafejlesztésre a nyílt pályázati rendszer keretében), ezért nélkülöz minden mesterséges feltételezést, szükítést, lehatárolást.

\section{FEJEZET}

\section{AZ EMPIRIKUS MUNKA MEGVALÓSÍTÁSA}

\subsection{A terv-tény projektpárok vizsgálata}

Az Észak-Alföldi Regionális Fejlesztési Ügynökség rendelkezésemre bocsátotta a Régió mind a 26 kistérségben, 2007-ben elkészült stratégiát, helyzetértékelést, projektlisták ütemezését és főbb adatait tartalmazó projekt adatlapokat. Két kistérséget jelöltem ki (a második a kontrollcsoportot jelenti), melyek kiválasztásában fontos szempont volt, hogy ne megye székhelyt tartalmazó és ne leghátrányosabb, ún. LHH térség legyen, mert azok speciális, kiemelt helyzete a dedikált források alapján eredménytorzító hatással bírnak. Célom volt két különböző térségi és gazdasági adottságú térség kiválasztása annak megítélése érdekében, hogy a mindkettőben levont következtetések összehasonlítása, és ezáltal a hipotézis bizonyítása megtörténhessen. A választásom a Jászberényi és Kisvárdai kistérségre esett, mert egyik sem tartozott a fent nevezett, torzítást jelentő besorolásokkal, de az eltérő gazdasági és térszerkezetü adottságaik jó alapot képeznek a megállapítások 
ellenőrzéséhez, hiszen az uniós transzferek allokációja országosan egységes eljárásrendben és jogszabályi környezetben zajlott/zajlik.

A két térségben 2007-ben az alábbi számú fejlesztési projekteket dolgozták ki.

3.táblázat: A Jászberényi és Kisvárdai kistérség település-és projektszámai

\begin{tabular}{|l|r|l|r|r|}
\hline $\begin{array}{l}\text { Terv/Tény: } \\
\text { Kistérségek }\end{array}$ & $\begin{array}{l}\text { TERV } \\
\text { (DB) }\end{array}$ & $\begin{array}{l}\text { TÉNY } \\
\text { (DB) }\end{array}$ & $\begin{array}{c}\text { TERV } \\
\text { (összes támogatás HUF) }\end{array}$ & $\begin{array}{c}\text { TÉNY * } \\
\text { (összes támogatás HUF) }\end{array}$ \\
\hline $\begin{array}{l}\text { Jászberényi: } \\
18 \text { település }\end{array}$ & 58 & 16 & 2201285 & 2300000 \\
\hline $\begin{array}{l}\text { Kisvárdai: } \\
\text { 29 település }\end{array}$ & 35 & 22 & 2242465 & 2350000 \\
\hline
\end{tabular}

Forrás: saját készítés az ÉARFÜ és az EMIR adatai alapján.

*Az EMIR rendszer adati a megítélt támogatásra vonatkozó adatokat tették közzé, melytől elmaradhat kis mértékben a ténylegesen lehívott támogatás.

Az összehasonlításból látható, hogy a kevesebb településsel rendelkező Jászságban jellemzően több fejlesztés is tartozott egy településhez, míg az aprófalvas térszerkezeti jellemzőkkel rendelkező Kisvárdai térségben - a térségközpont kivételével - szinte kizárólag egy-egy fejlesztést határoztak meg településszinten.

Látható továbbá, hogy a tervezett és tényleges forrásallokáció mindkét térségben közel megegyező volt, vagyis egy teljesen eltérő megvalósítási környezetben is sikeres LAU I-es szintü abszorpció valósult meg, a mennyiségi felhasználást kizárólag minőségi tényezők „csorbíthatják”.

Fontos megállapítás, hogy a teljes programozási ciklus tekintetében minden településen történt volna a lakossági közszolgáltatások területén, a település által leginkább szükségesnek itélt intézmény esetében fejlesztés az alábbi négy választható terület valamelyikéhez kapcsolódóan:

- alapfokú oktatási infrastruktúra, beleértve az óvodai intézményeket is

- egészségügyi alapellátást magában foglaló házi-és gyermekorvosi, védőnői és fogorvosi szolgáltatásoknak helyt adó épületek 
- szociális alapszolgáltatások keretében a bölcsődék, idősek nappali ellátása

- közösségi célú infrastruktúra, melyek - az előbbiekkel ellentétben jogszabályi lehatárolás hiányában döntően müvelődési házakat, sportcsarnokokat, klubhelyiségeket vagy intézményi konyhákat jelentettek.

A 2016-os, a programozási időszak végén rendelkezésre álló adatsort a Kormány elektronikus adatbázisa (Egységes Monitoring és Információs Rendszer, továbbiakban EMIR) biztosította, mely a statikus adatok kinyerését teszi lehetővé, vagyis a projekt megvalósulásának idejét, összegét, szűk tartalmát. Az adatbázisból nyert információk alapján a programozási periódus $n+2$. évének zárását követően a humán-infrastruktúra keretében az alábbi átlagos projektméretű fejlesztések valósultak meg ugyanazon fejlesztési cél mentén a két térségben, melyhez a 2007-es tervadatokat is feltüntetem.

4.táblázat: A két térség terv/tényadatai a humán infrastruktúra fejlesztése forráskeretben

\begin{tabular}{|l|c|r|}
\hline $\begin{array}{l}\text { Humán infra } \\
\text { tervezett/megvalósult projektek }\end{array}$ & $\begin{array}{c}\text { TERV (M Ft.-) } \\
\text { Átlagos projektméret }\end{array}$ & $\begin{array}{l}\text { TÉNY ( M Ft,-) } \\
\text { Átlagos projektméret }\end{array}$ \\
\hline Jászberényi & 38 & 139 \\
\hline Kisvárdai & 64 & 107 \\
\hline
\end{tabular}

Forrás: saját készítés az ÉARFÜ és az EMIR adatai alapján.

A fenti összehasonlításból az látható, hogy a forráskeretből a nyílt eljárásrenddel átlagosan fele annyi fejlesztés sem valósult meg, ez a fajlagos projektméretet a Kisvárdaiban másfél, a Jászberényiben közel négyszeresére növelte. Ez alátámasztotta azt a programirányítási szándékot, hogy a projektek elaprózódását megakadályozzák, mely a 2007-es térségi tervezés egyik legerősebb ellenérve volt.

A projekt-elaprózódás azonban sajnos mégis bekövetkezett a más célelőirányzatok forráskereteiből (KEOP - energetika és ÉAOP - akadálymentesítés) az e támogatáskeretből elmaradt, de ebbe a kategóriába tartozó intézmények fejlesztései 
helyett, igen szélsőséges mértékben, három és hat millió Forintos részleges felújítás is történt a potens épületeken.

Terjedelmi korlátok miatt a teljes, településenkénti terv-tény összehasonlítást elektronikus adathordozón a disszertáció függelékében bocsájtottam rendelkezésre. Ez két járás összesen 47 településének megközelítőleg kilencven fejlesztését vizsgálja az első teljes hazai fejlesztési időszak lezárásakor látható tényleges beruházásokkal történő összevetésben. A rendelkezésre álló információk későbbi, település-fókuszú további vizsgálatok kiindulási alapjaként is szolgálhat az értekezés megállapításainak mélyebb megértése és ellenőrizhetősége mellett.

A projektazonosság a térségi szelekciós eljárás és a nyílt eljárásrend között összesen a Jászságban 5, és a Kisvárdai kistérségben 4 esetben volt vizsgálható, vagyis a térségi szinten leginkább szükségesnek itélt feilesztések negved része sem valósult $\underline{\text { meg. }}$. Ahol a fejlesztés tárgya egyező volt a terv és tényadatok tekintetében, az alábbi megállapítások tehetőek a projektpárok összehasonlítását követően:

- A tényleges projektméret mindig elérte vagy meghaladta a tervezett méretet.

- A tényleges projektméret egyik költségnövekményét a járulékos költségek okozták, mintegy 5-15\%-ban. Ez jelentette az elszámolható előkészítési költségeket, az építészeti tervdokumentációkat, közbeszerzési, müszaki ellenőri, nyilvánosság biztosítása szolgáltatást, projekt menedzsment költségeit, továbbá kötelező módon előírt teljes körü akadálymentesítés többletköltségeit. A pályázati kiírás kifejezetten tiltotta a pályázatírás költségének elszámolhatóságát, azonban az általános gyakorlat azt mutatta, hogy ezek a költségek beépíthetőek és összevonhatóak voltak a járulékos költségek valamelyikével. A megvalósíthatósági tanulmány ezekben a kiírásokban nem volt elszámolható, azonban jellemzően más típusú fejlesztéseknél ez fedezte a tanácsadói költségeket. Az itt vizsgált projektekben számos esetben a megoldást az jelentette, hogy a tanácsadók részére elszámolt projektmenedzsment munka jelentős részét a cégek átterhelték az önkormányzat munkatársai részére. 
- A tényleges projektméret meghatározó költségnövekményét a többlet műszaki tartalom jelentette. Ez származott a jogszabályi kötelezettségből eredő, teljes körü akadálymentesítést elöíró müszaki megoldásokból, de leginkább az eltérő költségtervezési megfontolásból, mely a két eljárásrend közötti lényegi különbséget jelentette. Míg 2007-ben a térségi tervezéssel történt projektszelekció során az dominált, hogy a szükséges és elégséges fejlesztés megvalósulhasson, és más települési fejlesztések is részét képezhessék a közel egy évtizednyi településfejlesztési időszaknak, addig a nyílt pályázati eljárás során a bírálati szempontokban jelentős többletpontszámot és/vagy jelentős tanácsadói hátteret magáénak tudó települések egy, a költséghatékonyság helyett számára maximálisan elnyerhető forráshoz közelítették a projekttartalmat és a költségterveket. Lásd. az alábbiakban:

○ Jászkiséren az iskola 110 millió Ft-os tervezett beruházásértéke végül 534 millió Ft tényleges projektméretet jelentett

○ Jászladányban a 2007-ben tervezett 27 millió Ft helyett 81 M Ft-os költségvetéssel valósult meg az orvosi rendelő fejlesztése

○ Jászboldogházán az egészségház felújítása a 2007-ben 14 millió Ft-ra tervezett beruházási érték helyett 43 millió Ft-ért valósult meg

○ Gyulaháza iskolafejlesztése kétszeres projektköltségvetéssel valósult meg

- A térségi tervezéssel - tekintettel a településenként meghatározott költségkorlátokra - jelentős önerő hozzájárulásokat tartalmaztak a fejlesztések, míg a nyílt pályázati eljárásrend fent említett maximális elnyerhető forráslehetőségeit kimerítve az önerők eltüntek a fejlesztésekből. Például a jászfényszarui iskolafejlesztéshez az önkormányzat közel 40\%-os saját forrást vállalt 2007-ben, majd az elnyert pályázatban a kötelező 10\%-os önerő szerepelt, és másfélszeres projektméret a tervezetthez képest. 
- Költségvetés azonosság azokban az esetekben látható, ahol a 2007-es projektszelekció során a település egy későbbi - leginkább a harmadik akciótervi - időszakra sorolta a fejlesztést, mert valóban csak becsült költségszintet tudott még megadni.

- A projektmegvalósítások nem egy elöre meghatározott ütemezés szerint történtek, hanem a nyílt pályázati kiírások dinamikája szerint, melyekben egy legalább fél éves pályáztatási időszak, majd egy több hónapos szerződéselőkészítési időszak előzte meg a beruházást. Ez különösen az alapfokú egészségügy ellátást érintő fejlesztések esetében még n+1-es (2014. évi) támogatási szerződéskötést is jelentett. Ez a megvalósítási mód az intézményrendszer részéről is hullámzó megterhelést jelentett.

- A nyílt pályázati eljárásrendben a projektmegvalósítások elöre-jelezhetősége kiszámíthatatlanná vált. Ugyan a pályázati honlapon „partnerség” elnevezésű menüpontban lehetett látni a közeljövőben várható pályázati kiírás tervezetet társadalmasítás céljából, azonban számos esetben lényegi tartalomváltozás és kiszámíthatatlan ütemezés miatt a tényleges kiírásig csupán óvatos tervezések történtek. Számos településvezető megerösítette a 2007-es, tervszinten maradt ütemezett megvalósítás erre vonatkozó előnyeit, mely nemcsak a beruházás müszaki előkészítésének, hanem az épületek multi-funkcionalitása miatt hatékonyabb település-müködtetést eredményezett volna. Például egy települési közkonyhaként is müködő iskolakonyha felújítása esetében a szociális alapellátást nyújtó intézmény konyhája átvette volna átmenetileg az ellátási területet - ha nem éppen ott is ebből a fejlesztési keretből párhuzamos felújítás történik (ez középvárosi méretnél volt jelzett probléma mindkét térségben).

\subsection{Vizsgálati scope kiterjesztése a komplexitás érdekében}

A kontrafaktuális vizsgálatomat a kevés számú projektegyezőség miatt és programszinten a hatékonyságot fémjelző komplex területi szinergia értékelése érdekében kiterjesztettem arra vonatkozóan is, hogy településenként megnéztem milyen terv és milyen megvalósult fejlesztési térkép látható az alábbiak érdekében: 
- térség és települési szinteken hogyan alakultak a humán közösségi infrastrukturális fejlesztések egy évtized alatt, hiszen kijelenthető, hogy a hazai forrású célelőirányzatok teljességében megszüntek, így az itt jelentkező transzferek jelentették a területfejlesztés kizárólagos forrását a célterületen (minimális fejlesztési eredmény a Darányi Ignác Terv, vagyis az EMVA vidékfejlesztési pilléréből is megjelent, de az eredményre vonatkozóan nem szignifikáns hozadékkal)

- hogyan alakult a fejlesztések térségen belüli megoszlása

- a programciklus végére ténylegesen megvalósult, de a 2007-es felmérések során nem tervezett fejlesztések hátterének bemutatása

Mindkét térségre nézve kijelenthető, hogy a megvalósult projektek és ennek következtében a fejlesztési források allokációjának megoszlása erősen hektikus lett a tervezett egyenletesebb forráskihelyezés helyett. Az alábbi táblázat azt mutatja be, hogy mely településeken milyen realizált forrásabszorpció történt.

5.táblázat: Abszorpció szerinti település megoszlások

\begin{tabular}{|c|c|c|c|c|}
\hline Abszorpciós egyenleg & $\begin{array}{c}\text { Jászberényi } \\
\text { kistérségben } \\
\text { (település szám) }\end{array}$ & $\begin{array}{c}\text { Kisvárdai } \\
\text { kistérségben } \\
\text { (település szám) }\end{array}$ & $\begin{array}{l}\text { Jászberényi } \\
\text { kistérségben } \\
\text { (települések } \\
\text { aránya) }\end{array}$ & $\begin{array}{l}\text { Kisvárdai } \\
\text { kistérségben } \\
\text { (települések } \\
\text { aránya) }\end{array}$ \\
\hline $\begin{array}{l}\text { Térségi tervezés keretét } \\
\text { meghaladó forrásszerzés }\end{array}$ & 2 & 7 & $11 \%$ & $24 \%$ \\
\hline Nulla forráskihelyezés & 9 & 8 & $50 \%$ & $28 \%$ \\
\hline Kérdéses megítélésü & 4 & 3 & $14 \%$ & $10 \%$ \\
\hline Alig & 1 & 4 & $6 \%$ & $14 \%$ \\
\hline Torz & 2 & 7 & $11 \%$ & $24 \%$ \\
\hline
\end{tabular}

Forrás: saját készítés az ÉARFÜ és az EMIR adatai alapján. 
A kategóriák számaiból az olvasható ki, hogy a 2007-ben tervezettekkel ellentétben a lakossági alapszolgáltatásokat összefogó forráskeretből nem történt minden településen fejlesztés, ellenkezőleg a Jászságban a települések felében, a Kisvárdai kistérségben a települések közel egyharmadában semmilyen fejlesztés nem történt az elmúlt étvizedben. Amennyiben ehhez az értékhez hozzáadjuk a „torz” és az „alig” kifejezésekkel fémjelzett szintén negatív kategóriákat, a számadatokból az látható, hogy mindkét térségben eléri a kétharmadot azon települések száma, ahol kedvezötlen folyamatok történtek.

A „torz” jelzővel illetett kategóriába azokat a településeket soroltam, ahol a település által leginkább sürgető és indokolt célok egyáltalán nem, vagy részleges (energetikai - KEOP vagy akadálymentesítés - ÉAOP forrásból) mértékig valósultak meg, helyette azonban nyert el olyan épületre jelentős fejlesztési forrást, melyet nem akutnak ítélt. Ez nemcsak településvezetés, de talán lakossági szemszögböl még inkább rontja a racionális forrásfelhasználás megítélését. A példákat a teljesség igénye és a terjedelmi korlátok szűk keresztmetszetéből válaszottam:

- Mándok község önkormányzata 2007-ben egy 175 férőhelyes óvoda rekonstrukcióját tartotta a legszükségesebb fejlesztési igénynek, teljes rendelkezésre álló 150 millió Ft-os forráskeretét erre koncentrálva. A tíz év alatt egy részleges, kizárólag energetikai célú fejlesztés történt 49 millió Ft értékben az épületen, helyette azonban az orvosi rendelő komplex felújítására nyertek el és valósítottak meg 69 M Ft-ban fejlesztést.

- Tiszabezdéd község önkormányzata egy 300 adagos konyha felújítására és ezzel együtt egy 100 fős étkezde kialakítására 90 M Ft-ot nevesített 2007-ben, majd a fejlesztésből egy 16 millió Ft-os energetikai beruházás valósult meg, helyette a korábban nem jelzett orvosi rendelőt 36 millió Ftos költségvetéssel újították fel.

- Jászárokszállás városa két iskolafejlesztést is tervezett a 2007-es igényfelmérés során, azonban iskolafejlesztésre egyáltalán nem nyert el fejlesztési forrást (a két óvodára részlegesen igen), helyette azonban a 
fejlesztendőnek nem tartott egészségügyi alapellátásra 2013-ban 60 millió Ft.- vissza-nem-térítendő támogatást nyert el.

- Az időközben önálló járásközponttá vált Záhony város 200 millió Ft értékben tervezett forráskeretéből iskolai tornaterem építést, melyből semmi nem valósult meg, helyette ugyanezen forráskeretből a szociális alapellátás fejlesztésre nyert el 51 millió Ft-ot.

- A 27 ezer lakosú Jászberény több iskolája felújítását, két óvodafelújítást, és két ütemben kulturális negyed kialakítását jelölte meg 2007-ben a forráskerete terhére. A programciklus zárását követően azt látjuk, hogy egyetlen iskolája sem nyert fejlesztési támogatást, a két óvodafejlesztés helyett egy jobb indikátoradatokat felmutatni tudó óvodaközpont épült meg, valamint 2013-ban egészségház felújítás történt, és a kulturális fejlesztések egyike önerőből, a másik turisztikai célú kiúrás keretében valósult meg (utóbbi jogosultsága a turisztikai megfelelőség tekintetében vitatható).

Az „alig” kategóriába azokat a településeket soroltam, ahol a fejlesztendő intézmények a humán infrastrukturális fejlesztési forrásból semmit, helyette egy részleges (energetikai - KEOP vagy akadálymentesítési - ÉAOP) célra nyertek el marginális támogatást. Néhány példa a teljesség igénye nélkül:

- Pap községben a 115 millió Ft-osra tervezett iskolafejlesztés elmaradt, helyette egy energetikai 20 millió Ft értékü fejlesztést valósíthatott meg az iskola és óvoda együttes kezelésében az önkormányzat.

- Újkenéz község önkormányzata egy 55 M Ft-os tornaterem bővítés helyett az óvodára nyert el egy 15 millió Ft-os energetikai fejlesztést.

- Szabolcsveresmart 89 millió Ft-os, étkezdebővítéssel kiegészített iskola felújítást tervezett 2007-ben a saját forráskeretéből. Ebből a teljes 20072015-ig tartó időszakban semmit nem realizált. A programciklusban két akadálymentesítést nyert el 6-6 millió Ft.- értékben az óvodára és az egészségházra. 
A táblázatban nevesített további települések a függelékben elektronikus adathordozón rendelkezésre bocsájtott elemzésekben olvashatóak.

A „kérdéses” jelzőt kiérdemlő települések közül valamennyiről elmondható, hogy közel annyit, vagy többletforrást realizált a 2007-ben tervezettekről, ugyanakkor a fejlesztés nem az általa leginkább szükségesnek ítélt intézményen valósult meg. Ennek kirívó példája az egészségügyi alapellátás fejlesztésére kiírt pályázatok helyzete.

Az alábbi táblázatban összegeztem, mely települések érintettek az egészségügyi alapellátás fejlesztésével, és a lehetséges három kategóriába soroltam a beruházásokat.

6.táblázat: A két térség egészségügyi alapellátásra vonatkozó fejlesztéseinek alakulása

\begin{tabular}{|c|c|c|c|c|}
\hline & \begin{tabular}{|c|}
$\begin{array}{c}\text { Tervezett és megvalósult } \\
\text { (millió Forint) }\end{array}$ \\
\end{tabular} & $\begin{array}{c}\text { Tervezett és } \\
\text { nem nyert }\end{array}$ & $\begin{array}{l}\text { Nem tervezett, } \\
\text { de lett (millió Ft) }\end{array}$ & $\begin{array}{c}\begin{array}{c}\text { Ebböl 2013-ban } \\
\text { (millió Forint) }\end{array} \\
\end{array}$ \\
\hline Jászberényi & $\begin{array}{c}\text { Jászkisér, (53/69) } \\
\text { Jánoshida, (24/66) } \\
\text { Jászladány,(25/81) } \\
\text { Jászboldogháza(14/43) }\end{array}$ & $\begin{array}{c}\text { Jászágó (13) } \\
\text { Pusztamonostor (23) } \\
\text { Jászfelsőszentgyörgy } \\
(15)\end{array}$ & $\begin{array}{c}\text { Jásztelek (27) } \\
\text { Jászárokszállás } \\
(60) \\
\text { Jászberény (66) } \\
\text { Jászberény (66) } \\
\text { Jászfényszaru } \\
\text { 69M }\end{array}$ & $\begin{array}{c}\text { Jászfényszaru } \\
(69) \\
\text { Jászárokszállás } \\
(60) \\
\text { Jászberény (66) } \\
\text { Jászboldogháza } \\
(14 / 43)\end{array}$ \\
\hline Kisvárdai & - & $\begin{array}{c}\text { Döge (39) } \\
\text { Szabolcsbáka (11) } \\
\text { Anarcs(14) }\end{array}$ & $\begin{array}{c}\text { Mándok (69) } \\
\text { Kisvárda 59M } \\
\text { Tuzsér (47) } \\
\text { Ajak (60M) } \\
\text { Tiszamogyorós } \\
(58) \\
\text { Pátroha (69) } \\
\text { Nyírlövoó (55) } \\
\text { Mezőladány (58) } \\
\text { Kécske (60M) } \\
\text { Tiszabezdéd (36) }\end{array}$ & $\begin{array}{c}\text { Mándok (69) } \\
\text { Kisvárda (59) } \\
\text { Tuzsér (47) } \\
\text { Ajak (60M) } \\
\text { Pátroha (69) } \\
\text { Nyírlövő (55) } \\
\text { Mezőladány } \\
\text { (58) } \\
\text { Kécske (60M) }\end{array}$ \\
\hline
\end{tabular}

Forrás: saját készítés az ÉARFÜ és az EMIR adatai alapján.

A táblázatból jól látható, hogy négy olyan település van, ahol a település által 2007ben nevesített és később a nyílt eljárásrendben meg is valósult fejlesztés történt. A 
korábban említett költségnövekményt mindegyik esetben látjuk a zárójeles terv/tény adatokban. Másfélszer ennyi település esetében a jelzett igény ellenére nem valósult meg egészségház felújítás, ez származhat pályázási hiányból és elutasított pályázatból is. Mindkét esetben vizsgálható, hogy ez a szándék változásából, vagy az intézményrendszer és/vagy az eljárásrend következménye. Látható azonban, hogy kiemelkedő azoknak a beruházásoknak a száma, melyeket a települések nem tartottak a tíz év alatt fejlesztendőnek (vagy leginkább fejlesztendőnek), de mégis jelentős forrásokat nyertek el hozzá. Külön kiemelésre méltónak tartottam a 2013-ban megjelent pályázati kiíráson elnyert 12 projektet, melyek jelentős arányban közelítettek a maximális projektmérethez (mely egyben a realizálható 100\%-os támogatatás intenzitásnak köszönhetően az elnyert támogatás is volt.). Az is kiderült, hogy az egészségházak fejlesztésének számos korábban nem tervezett beruházására 2013-ban azért is pályáztak a települések, mert ekkorra látható volt, hogy a tervezett negyedik cél, a közösségi célú infrastruktúra feljesztési lehetőség az operatív program tartalma ellenére nem kap forráskeretet. Sajnos így számos olyan fejlesztés maradt el, mely egy település lakossága számára valódi jóléti beruházást jelentett volna pl. a tornacsarnokok megépítésével, klubhelyiségek kialakításával, müvelődési házak felújításával, térségközpontban pedig ún. kulturális negyed ütemezett fejlesztésével nem számolhattak a települések. Utóbbi esetében a beruházás turisztikai célú attrakciófejlesztés keretében részlegesen megtörtént, de annak turisztikai jellege kevésbé indokolt, mint a lakossági igény.

Az egészségházak megújításának témájában egy települést kiemelésre méltónak tartok, mert jól szemlélteti a két eljárásrend közötti különbséget. Jászboldogháza 2007-ben a dedikált forráskeretek alapján közel 49 millió Forint felhasználásáról dönthetett volna az induló programozás ciklus elején. Egyeztetett képviselő testületi döntéssel három fejlesztési területet jelöltek meg, a települési tornacsarnok felújítását 16,6 millió Forint, az iskola-óvoda felújítását 26 millió Forint, az egészségház felújítását 14,85 millió Forint összköltségben. A nyílt pályázati eljárás keretében csak az egészségház felújítására nyert el pályázatot,de első körben 2010-ben a pályázat elutasításra került formai okokból, majd 2013-as kiírás során nyert el végül támogatást. 


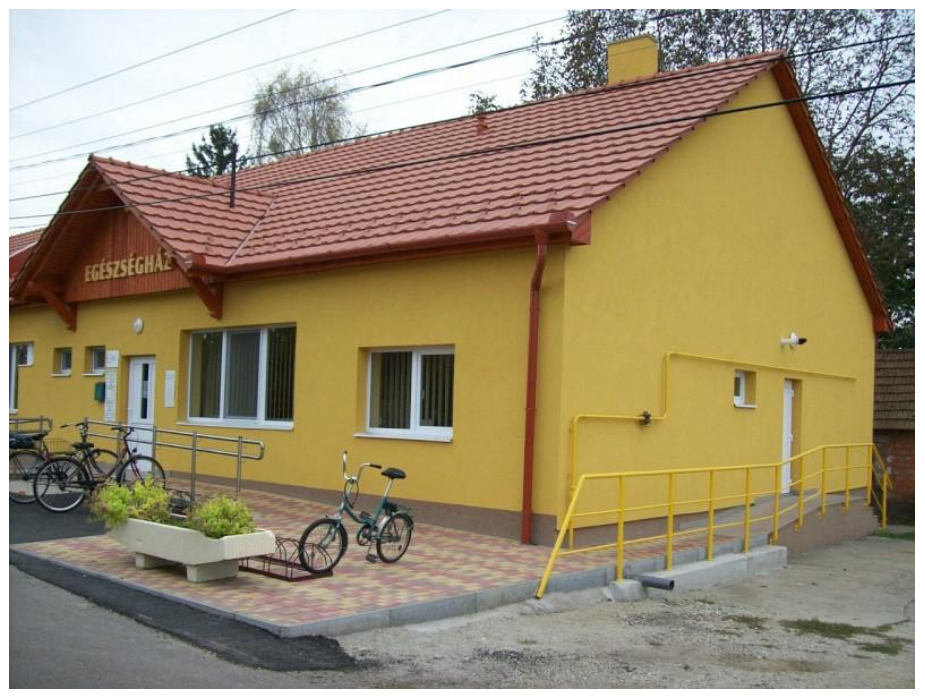

2. kép: Jászboldogháza felújított egészségháza 2014ben

Forrás:

Jászboldogháza honlapja: http://www.jaszboldoghaza.h $\underline{\text { u/egeszseghaz-fejlesztese- }}$ jaszboldoghazan/590

A projekt összértéke a három időszakban az alábbiak szerint alakult:

7. táblázat: Jászboldogháza egészségház felújításának pályázati története

\begin{tabular}{|c|c|c|c|}
\hline $\begin{array}{c}\text { Községi } \\
\text { Önkormányzat } \\
\text { Jászboldogháza }\end{array}$ & $\begin{array}{c}\text { 2007." Beosztó" } \\
\text { forrásfelhasználás }\end{array}$ & $\begin{array}{c}\text { 2010. Nyílt } \\
\text { pályázás } \\
\text { elutasító döntés }\end{array}$ & $\begin{array}{c}\text { 2013. Nyílt pályázás } \\
\text { támogató döntés }\end{array}$ \\
\hline $\begin{array}{c}\text { Egészségház projekt } \\
\text { összértéke ( M Ft.-) }\end{array}$ & 14,85 & 29 & 43 \\
\hline
\end{tabular}

Forrás: saját készítés ÉARFÜ és EMIR adatbázis, és projektmenedzseri mélyinterjú

Jól látható, hogy a programozási ciklus végére a község közel megegyező mértékủ támogatást kapott és használt fel, mint a 2007-ben tervezési rendelkezésre álló kerete, azonban a másik két nevesített cél (mindkettőt fontosabbnak ítélte a megvalósulttól a testület) teljesülése elmaradt. A fenti tények képzeték a folyamat besorolásának „kérdéses” kategóriáját.

A biztosan kedvező települési megítélésű tíz évként értékelt területfejlesztési folyamatot tud felmutatni mindkét térségben egy-egy település, melyek kirívóan nagy forrást nyertek el méretük és térségi szerepükhöz képest. A Jászságban ez 
Jászkisér (mely időközben nyert el városi rangot), míg a Kisvárdai térségben Kécske község.

Jászkisér egy közel 6000 fős település, ezzel lakosságarányát tekintve az ötödik legnagyobb település a Jászságban. Forráskeretét a térségi tervezés során két épületre nevesítette: az általános iskolája 110 millió Ft-os értékü felújítását és egy 60 millió egészségház rekonstrukciót. Utóbbi azon kevés beruházás egyike, mely a tervek szerint megvalósult 2014-ben. A közoktatás fejlesztésében a nyílt pályázati kiírás során látható volt, hogy a jelentős többletpontszámot eredményező SNI-indikátor (sajátos nevelési igényű gyermek) miatt a maximális támogatásra is igen kedvező eséllyel pályázhat (jelentős a cigány lakosság aránya), így intézmény-összevonással és jó indikátoradatokkal 534 millió Ft-os beruházást valósított meg. Ez jelentette a tanmedence megújítása mellett hat - vagyis valamennyi - közoktatási intézmény épület megújítását óvoda és iskolai szinten egyaránt.

Kécske egy 1500 lelkes település a Kisvárdai járásban, mely 2007-ben a müvelődési háza felújítását nevesítette 45millió Ft-os forráskeretéből. A számára kedvező nyílt eljárásrendi pályázati körülményekből az elmúlt évtizedben 14-szeres forrást realizált: 447 millió Forint költségvetésü közoktatási infrastruktúra fejlesztést valósított meg, mellette pedig a 2013-ban népszerü és általában 60 millió Ft-os projektértékü egészségház megújítására is lehetőséget nyert. A kiugró adatokat tovább árnyaljuk, ha figyelembe vesszük, hogy a térségben a kétszeres lakosságszámú Pátroha 2007-ben jelzett és tervezett egy 240 M Ft-os iskola felújítást tornaterem építéssel, melyből egy 21 millió Ft-os energetikai beruházás valósult meg csupán, hasonlóan Pap községhez. Ráadásul a térségi kötődésű fejlesztéspolitikai szaktárca munkatársa a kvalitatív mélyinterjú során Kécske kapcsán már müködési nehézségeket jelzett.

A településvezetőkkel tervezett, újabb kvalitatív mélyinterjúkat (a 2007-es térségi tervezési eljárás kapcsán az akkori munkám jóvoltából megvalósítottam) nem folytattam le, az objektivitást jelentősen korlátozó alábbi tényezők miatt:

- amennyiben településvezető váltás történt, akkor a folyamat megítélését személyes/szubjektív szempontok is befolyásolják 
- a 2007-2015-ig párhuzamosan zajló fejlesztési folyamatokat „enyhítő körülményként" értékelték a térségi szereplők (pl. városok esetében a főtérprogramként összegzett funkcióbővítő város-rehabilitációk, a kisebb településeken a szennyvíz-belvíz-ivóvízminőség javító programok beruházásai). Ez azonban nem helyettesíti természetesen az adott fejlesztési célt és az egyes projektek hatékonysági elvárásait.

a. A tényellentétes vizsgálat következtetései a hatékonyság definíciós kritériumai alapján és a hipotézisek bizonyítása

A fejezetben kiemelten a második hipotézis első két alpontját bizonyítom:

H2a: Az intézményrendszer müködésében, müködési struktúrájában érvényesített adekvát szubszidiaritás és legitim partnerség javítja a hatékony felhasználást.

$\mathrm{H} 2 \mathrm{~b}$ : A programtervezés, projektgenerálás, projektkiválasztás során megjelenő adekvát szubszidiaritás és legitim partnerség javítja a hatékony felhasználást.

A térségi szinten lefolytatott - vagyis az adekvát szubszidiaritást és legitim partnerséget képviselő - 2007-es humán erőforrás fejlesztésének forrásait felhasználó megoldás helyett a nyílt pályázati kiírások rendszerében:

- projektazonosságoknál (nagyon kevés eset): időben 2-3 év csúszás, nagyobb projektméret (akkor nem, ha a második felére esett a periódusnak, és becsült költséggel), amit az intézményrendszeri járulékos költségek és a kiterjedtebb müszaki tartalom okoztak

- a nagyobb müszaki tartalom a magasabb támogatás intenzitás és maximálisan nagyobb támogatási összeg lehetősége miatt alakult, nem feltétlenül a szükségesség okán

- a programszinten elvárt területi szinergia súlyosan sérült a megvalósulás teljes képét áttekintve: egyharmadnyi település közel elfogadható kimenete mellett jelentős számú, mindkét irányban azonosított kiugró 
forrásallokációt mutatott, ugyanakkor mindkét térségben közel azonos terv/tény abszorpcióval

- az átláthatóság projekt és program szinten is kevésbé érvényesült a nyílt pályázati eljárással megvalósított projektszelekció során, ez növelhette az információmonopólium és járadékvadászat veszélyét a heterogén tanácsadói szolgáltató piac következményeként

- partnerség - iterativitásra is érvényes az előző megállapítás

- a kimentek tükrében az adekvát szubszidiaritás hiánya eredményezte a projekt és programszintű problémákat

- saját erő vállalása: 2007-ben a kötelező 10\%-ot mindenki hozzárendelte, sőt jelentős túlvállalások is láthatóak voltak a nagy adóerővel rendelkező települések részéről a települési forráskeret beosztó felhasználása érdekében. A tényleges megvalósulásnál kihasználva az akár 100\%-os támogatás-intenzitásokat, valamint a nagyobb maximális támogatás összegét, szinte eltünt a saját erő a programból

- Ütemezés: általánosan kimutatható egy minimum 2 éves csúszás, de volt 2014-ben aláírt támogatási szerződés pl. egészségházak esetében $(n+1$ !), ez jelentős abszorpciós veszélyeket hordoz

- szélsőséges terv/tény projektméretek: az intézményrendszer részéről az elaprózottságtól való félelem a megvalósult projektkiválasztással valóban nem valósult meg, de a legjobb fajlagos költségráfordítás sem. A szintén megjelent kiegészítő forrásokban a projektméret és részlegesség is problémát jelentett (ÉAOP - akadálymentesítés és KEOP - energetika)

- a helyi döntéshozók által legszükségesebbnek ítélt fejlesztések közel negyede valósult csak meg

A fentiek tükrében bizonyítottnak látom a két hipotézisemet, ahol az adekvát szubszidiaritás kérdését még egy további tény is erősíti.

Különös adaléka a feltárt helyzetnek, hogy a 2014-2020-as fejlesztési periódus Terület-és Településfejlesztési Operatív Programjában ismét zajlott egy helyi szintet 
bevonó tervezési munka. A jelen vizsgálatom első adatsorát szolgáltató 2007-es, alulról építkező eljárásrendhez hasonló tervezés indult el országosan, elsősorban az önkormányzati fejlesztéseket illetően a Megyei Területfejlesztési Ügynökségek koordinálásával a Partnerségi Megállapodás társadalmasításával párhuzamosan. A megyei szinten allokált forrásokkal is rendelkező tervezési munka feltételezhette volna az eredményes kimenetet, de ismét nyílt eljárásrendszerü pályázati megvalósítás irányába mozdult el a végleges megoldás. Okai között a második részben feltárt hazai intézményi változások is szerepelnek, vagyis a megyei szinten megjelenő területfejlesztési szervezetek nem rendelkeznek a 2007-2013-as programozási időszak tapasztalataival, térségi szintű területfejlesztési információik és az ehhez szükséges humán erőforrás kapacitásuk nem állt rendelkezésre, így az új időszak OP-jaihoz lehetéses inputot adó Megyei Területfejlesztési dokumentumok =helyzetfeltárás, stratégia, program) több esetben általánosító, kívánság-lista típusú és nem racionális döntés-előkészítést lehetővé tévő dokumentumok. Továbbá nem jelentette az adekvát szubszidiaritás szintjét sem, a kistérség/járás szintü területfejlesztés megszüntetésével megnőtt a távolság a települések és megyei szint között. Ez a korlátozott humán kapacitás és az elmúlt egy évtized eltérő gyakorlata miatt nem kapcsolódhatott össze. A szaktárca számára a fenti problémák miatt kétségesen védhető megoldássá vált az ehhez szükséges forrás-kihelyezési eljárásrend engedélyezése, ahogy ezt a kvalitatív interjúk során megtudtam.

A félig strukturált interjú kvalitatív kutatási technikának számít; célja, hogy az interjúalany életvilágáról (valóságfelfogásáról) gyüjtött információt, az interjúalany által elbeszélt jelenségeket a kutatási kérdés szempontjai szerint interpretálja [Csite,Szepesi 2008.]. Az interjúk az értékelésben egyrészt az adatelemzésben feltárt folyamatok validálására és értelmezésére szolgálnak, másrészről a fejlesztéspolitika helyi és központi szintü alakításában résztvevők döntései mögötti motivációkat, percepciókat tárják fel, harmadrészt ezek segítségével tárom fel azoknak a koordinációs, programszintű mechanizmusoknak a valós müködését, amelyeket a fejlesztéspolitika hozott létre az eddigi hazai regionális politika érvényesítése érdekében.

Félig strukturált interjút folytattam le a regionális szinten a 2007-2013-as programozási periódusban a térségi tervezés kulcsszereplöjének tekinthető 
Regionális Fejlesztési Ügynökség Nonprofit Kft. akkori vezetőjével, dr. Debreczeni Ferenccel, aki elmondta, hogy - bár személyesen Ö is volt olyan tagállami tanulmányúton, ahol a 2007-es térségi módszer szerinti forrásallokáció történt - az intézményrendszer nem kívánt egy ismeretlen, újabb projektszelekciós eljárást bevezetni, magasabbnak ítélte a kockázatát, mintsem a pozitív hozadékait. Ez visszavezethető az intézményrendszeri partnerség elégtelen voltára.

Az Európai Bizottság Regionális Politikai Főigazgatóságának elismerésével müködő, a második részben bemutatott EVALSED módszertani ajánlásai között szerepel annak a szempontnak a vizsgálata a hatékonyság égisze alatt, hogy más eszközökkel jobb eredményt lehetett volna elérni. A vizsgálat konklúziójaként a programszintü definíció kritériumait vizsgálva is kijelenthető, hogy a tervszinten maradt térségi együttmüködéssel kialakított projektszelekciós eszközzel hatékonyabb, és talán eredményesebb területfejlesztést lehetett volna elérni. Utóbbi megítéléséhez összesített indikátoradatokra lett volna szükség a megvalósult fejlesztések kapcsán, bár szintén vizsgálat tárgyát képezheti, hogy azok valóban a célnak legmegfelelőbb indikátorok voltak-e (pl. SNI indikátorok okozta torzulások). Az Európai Unió számára kiemelten fontos nyilvánosság biztosítása érdekében a minél nagyobb tájékoztató táblák, és olykor túlzó rendezvények helyett jobb, ha a fejlesztések önmagukért beszélnek, mert racionális igény, nem pazarló kivitelezés és hosszú-távú elképzelések mentén született elképzelések, melyek nemcsak tervszinten maradnak. A helyi tervezés és dedikált forráskeret meghatározása mellett még egy érv szól: a döntés felelössége nem terhelhető át másra, egy kiszámíthatatlan intézményi bonyolításra, esetleges járadékvadász pályázatírókra, a fejlesztéspolitika szaktárcára. A helyi önkormányzatiság lényege valósul meg annak minden lehetséges negatív, és pozitív hozadékával, de helyi lakosság általi számon kérhetőség mellett. 


\section{KÖVETKEZTETÉSEK}

A gazdasági válsággal is terhelt 2007-2013-as költségvetési periódus tapasztalatai alapján mind tartalmi, mind abszorpciós teljesítést tekintve egyaránt szigorúbb szabályozási rendszert alakított ki az Európai Unió Bizottsága a 2014-2020-as fejlesztéspolitikai forráskeret tekintetében egy 25 hónapos tagállami érdekegyeztetési folyamat eredményeként. A hatékonyabb felhasználás igénye - melyet a 2009-ben kiadott ún. Barca-jelentés a minőségi költés fogalmával újradefiniált - mind a nettó befizető tagállamok egyre élesedő elvárásait tükrözte, és abból a tényből is származott, hogy a teljes kohéziós fejlesztéspolitika során most szembesülhettünk először a korábbiaktól kisebb forráskeret létrehozásával [Barca 2009]. A csökkentésnek nem annyira mértéke, mint maga a tendencia megfordulása beszédes egy bővülő/bővülés lehetőségét nem kizáró közösségben.

A 2014-2020-as kohéziós fejlesztéspolitikában megfogalmazott új elvárások látszólag a minőségi költést szolgálják, ugyanakkor a rugalmatlan, túlzott mértékü tematikus és pénzügyi elvárások és a programozási dokumentumok összhangba hozása a tagállami fejlesztési környezettel olyan mértékü kihívás elé állították az intézményrendszert, melynek csak úgy tudnak megfelelni az egyes szereplök, hogy a valódi, tartalmi tervezésre, újragondolásra alig maradt idő.

Az értekezésben bemutatott - eredetileg - hatékonyság-fókuszú jogszabályi változások a tagországok intézményi és programozási feladatainál nemcsak késedelmes, de erős szük keresztmetszeteket adtak. A tematikus koncentrációban megtestesülő forrásarányos allokációs előírások, és az ún. EU2020 célkitüzések vállalásai, valamint az egyes operatív programok önálló szabályozás-rendszere egy közel négy-dimenziós mátrix-rendszerü tervezési kihívás elé állította a tagállamokat, melyek egyszerre néztek szembe a 2007-2013-as programozási periódus n+1. évben (2014-ben) annak abszorpciós, és tartalmi vállalásainak teljesítésével, valamint az új időszak késedelmes, még koncentráltabb, kötött, és sok esetben nem véglegesedett elöírásaival a programalkotás idején. 
Az első részben végzett intézményi és szabályozási környezet szintetizáló munka eredményeként bizonyított a H1 hipotézis, vagyis az intézményrendszer kialakítását és müködését meghatározó jogszabályi rendszer determinál hatékonysági problémákat. Az első részben ez uniós szinten, majd a második és harmadik részben tagállami szinten is bemutatásra került.

A tartalmi kötelezettségek mellett a határozottabb számonkérés is megjelenik az új programozási periódusban, ennek kiemelt területe a minőségi költés, vagyis a hatékony felhasználás, jóllehet a fogalmat sem uniós, sem tagállamok szintjén nem definiálták egységesen és mérik összehasonlítható módon.

Kutatásom épít Kengyel Ákos habilitációs értekezésében bizonyított harmadik hipotézisre, mely szerint az EU kohéziós politikájának szabályozási kereteit elemezve megállapította, hogy a támogatási rendszer nem egy jóléti transzfermechanizmus, hanem nagyon szigorú feltételrendszer alapján müködő fejlesztéspolitika. Disszertációm abban egészíti ki munkásságát, hogy a hazai fejlesztéspolitikai dokumentumokon keresztül láttatja a szintén itt jelzett problémát, hogy az Európa 2020 stratégia tematikus célkitüzéseihez való kapcsolódás túl sok tevékenység támogatását teszi lehetővé (írja elő), ezáltal a kívánatos koncentráció helyett éppen ellentétes irányú folyamat következik be (Kengyel [2015b]).

A nemzetközi és magyar szakirodalmi és kutatási környezet széleskörü vizsgálata további két eredményt is hozott a teoretikai kérdések mellett. Különösen a brit példára tekintettel azt láthatjuk, hogy egy különálló intézmény felel - és a Parlament Alsóházának jelent - a támogatások felhasználásáról, annak koordinált ellenőrzésével és az uniós előírásokon túli belső igény vezérelte iránymutatással. Második pozitív externáliaként azonosítottam azokat a további tagállami vizsgálati gyakorlatokat, melyekkel a transzferek felhasználását értékelik. Mindkét eredmény hazai adaptációja vizsgálandó és az értekezés átfogó céljához járul hozzá.

A tagállami mérési gyakorlatok összegzéseként, valamint a hatékonyság-fókuszú szakirodalom eddigi eredményei alapján projekt-és programszinten egyaránt is igyekezett pótolni a fogalomalkotást.

A projektszintủ definíció így foglalható össze: 
A helyes célt, a legjobb fajlagos költség ráfordítással és ütemezéssel, egy megfelelő intézményrendszerben megvalósító felhasználás tekinthető hatékonynak. A megfelelő intézményrendszer paraméterei az alábbi feltételek mentén teljesülnek:

1. szubszidiaritás

2. partnerség/ügyfél-barát megközelítés (beépíthető visszacsatolás)

3. rugalmasság

4. elöre-jelezhetőség

5. átláthatóság

6. állandóság

7. minimalizált járadékvadászat és információmonopólium

A programszintű hatékonyság számos tagállami példája egységes uniós szabályozás hiányában nem megalkotott, jóllehet valamennyi tagállam nevesíti elvárásként ezt a szempontot a forrásfelhasználás során. Az értékelési gyakorlatok szintézise alapján programszinten az alábbi feltételek teljesülésével tekinthető hatékonynak a kohéziós források felhasználása:

Program szinten az alábbi kritériumok fémjelzik a hatékonyságot:

1. elöre-jelezhetőség

2. rugalmasság

3. jövő-orientált tervezés

4. folyamat-közbeni monitorozás és értékelés

5. területi szinergia,

6. visszacsatolás lehetősége

Fontos megjegyezni, hogy a projektszinten megfogalmazott hatékonysági kritériumokat programszinten is biztosítani szükséges, illetve megfordítva: a programszintű hatékonyság szükséges, de nem elégséges feltétele a projektszintü hatékonyság érvényesülése. 
Az első részben bemutatott - eredetileg - hatékonyság-fókuszú uniós jogszabályi változások a tagországok intézményi és programozási feladatainál nemcsak késedelmes, de erős szük keresztmetszeteket adtak, melyet a magyarországi intézményi és a 2014-2020-as programozási feladatok bemutatásával tettem kézzelfoghatóvá. E nehezített körülmények között hazánk a regionális tervezés szintjeinek teljes átalakításával az alulról történő igény-meghatározáskor valamennyi megyének lehetőséget adott az ismét megerösített fejlesztési szinten területfejlesztési programalkotásra. A 2014. és 2023. között megvalósítani kívánt operatív programokat annak tükrében elemeztem, hogyan találkozott a két alapelv - adekvát szubszidiaritás és legitim partnerség - teljesülésének hiányával a térségfejlesztés új legalsó szintjén, a megyéknél. Az elemzésből megállapítható, hogy a 2012-ben végrehajtott intézményi és térségfejlesztési átalakítás nem tudott jó válaszokat adni az azt követő két fontos évben a visszajelzéseket váró intézményrendszernek. Egy megyei területfejlesztési program és a 2014-2020-as operatív programok találkoztatása során jól látható, hogy az újonnan megerösített megyei térségi szereplők nem képviselhették a megfelelő szubszidiaritási szintet. Ez a tervezés során megszólítottak körét és a programalkotók szakmai felkészültségét, kapacitását is mutatja, mely így nem szolgálhatott érdemi inputként a készülő OP-khoz, és nem testesítették meg a legitim partnerség kritériumának teljesítését.

\section{Annak a veszélye az elmúlt évtized tapasztalati és az uniós tervezési folyamat ellentétes eröfeszítései ellenére is fennáll, hogy a fejlesztési források a támogatottak/kedvezményezettek szemszögéböl ismét átláthatatlan és kevésbé illeszkedö módon kerülnek felhasználásra.}

A disszertáció második részét alkotó illusztratív esettanulmány, és a kisebb esetleírások, valamint a harmadik részben kimunkált kontrafaktuális összehasonlító vizsgálat a második hipotézis mindhárom részét bizonyítják, és arra is rávilágítanak, hogy a tagállamok közötti érdemi, operatív egyeztetés nemcsak a forráskeretek kialakítása során indokolt, hanem a megvalósítás éveiben is jogos igény. Az együttmüködés a végrehajtási közösségi rendeletek értelmezésében, hatékony és erősebb érdekképviseletében - ezáltal kevesebb kötelezettségszegési eljárást eredményezve - nyilvánulhatnak meg. A lehetséges további kutatási téma ezen együttmüködések feltárásának lehetőségeit, valamint a nemzetközi gyakorlatok során feltárt koncentrált, koordinált hatékonyságvizsgálatok szükségességét jelöli ki hazai 
adaptáció érdekében. Utóbbi nem csak az uniós elöírások teljesítése miatt, hanem (sokkal inkább) egy belső igény vezérlete felülvizsgálat céljából.

Kutatásom célját igyekeztem teljesíteni azáltal, hogy a kohéziós támogatások hatékony felhasználását javaslatokkal segítsem elö a hazai és bizottsági intézményrendszeri szabályozás szintjein, valamint a hatékonyságot eredményezö beavatkozási lépéseket azonosítsam a tagállami tervezési és megvalósítási szakaszokban egyaránt.

Az Európai Bizottság Regionális Politikai Főigazgatóságának elismerésével müködő, a második részben bemutatott EVALSED módszertani ajánlásai között szerepel annak a szempontnak a vizsgálata a hatékonyság égisze alatt, hogy más eszközökkel jobb eredményt lehetett volna elérni. Ezt a kérdést a harmadik részben bemutatott kontrafaktuális összehasonlítás kertében megvizsgáltam. A vizsgálatban két járás összesen 47 településének terv-tény elemzését végeztem el, a teljes adatbázis és a számítások eredményét alátámasztó anyag a függelékben elektronikus adathordozón a disszertáció részét képezi. Ez a településenkénti terv-tény összehasonlítás megközelítőleg kilencven tervezett fejlesztés történetét vizsgálja az első teljes hazai fejlesztési időszak lezárásakor látható tényleges beruházásokkal történő összevetésben. A rendelkezésre álló információk későbbi, település-fókuszú további vizsgálatok kiindulási alapjaként is szolgálhat az értekezés megállapításainak mélyebb megértése és ellenőrizhetősége mellett.

A munka konklúziójaként programszinten az is kijelenthetö, hogy a tervszinten maradt térségi együttmüködéssel kialakított projektszelekciós eszközzel hatékonyabb, és talán eredményesebb területfejlesztést lehetett volna elérni. Utóbbi megítéléséhez összesített indikátoradatokra lett volna szükség a megvalósult fejlesztések kapcsán, bár szintén vizsgálat tárgyát képezheti, hogy azok valóban a célnak legmegfelelőbb indikátorok voltak-e. Az Európai Unió számára kiemelten fontos nyilvánosság biztosítása érdekében a minél nagyobb tájékoztató táblák és olykor túlzó rendezvények helyett jobb, ha a fejlesztések önmagukért beszélnek, mert racionális helyi igény, nem pazarló kivitelezés és az előrelátó gondolkodás mentén született elképzeléseken alapulnak, melyek nemcsak tervszinten maradnak. A helyi tervezés és dedikált forráskeret meghatározása mellett még egy érv szól: a döntés felelőssége nem terhelhető át másra, egy kiszámíthatatlan intézményi 
bonyolításra, esetleges járadékvadász pályázatírókra, a fejlesztéspolitikai szaktárcára. A helyi önkormányzatiság lényege valósul meg annak minden lehetséges negatív, és pozitív hozadékával, de a helyi lakosság általi számon kérhetőség mellett.

Hipotéziseim bizonyitásával láthatóvá vált, hogy a szubszidiaritással és partnerséggel meghatározott fejlesztések hatékonyabbak az ezt nélkülözö megoldásoktól, kimenetektől. A két alapelv érvényre jutását meghatározza az intézményrendszer és annak elözményeként létrehozott jogszabályi környezet mind uniós, mind tagállami szinten egyaránt.

A hipotézisek bizonyítására használt módszerek arra is rávilágítanak, hogy $\boldsymbol{a}$ tagállamok közötti érdemi, operatív egyeztetés nemcsak a forráskeretek kialakítása során indokolt, hanem a megvalósítás éveiben is jogos igény. A nemzetközi együttmüködés a végrehajtási közösségi rendeletek értelmezésében, hatékony és erősebb érdekképviseletében - ezáltal kevesebb kötelezettségszegési eljárást eredményezve - nyilvánulhatnak meg. A lehetséges további kutatási téma ezen együttmüködések feltárásának lehetőségeit, valamint a nemzetközi gyakorlatok során feltárt koncentrált, koordinált hatékonyságvizsgálatok szükségességét jelöli ki a hazai adaptáció érdekében. Utóbbi nem csak az uniós elöírások teljesítése miatt, hanem sokkal inkább egy belsö igény vezérlete felülvizsgálat céljából. Az ismét virágkorát élő Visegrádi Négyek együttmüködéseinek lehetséges területe lehetne a megvalósítási tapasztalatok, és megfelelő végrehajtási rendeletértelmezések egyeztetése, közös bizottsági érdekképviselete.

A disszertációban feltárt, fenti eredményeket hozó dokumentum-elemzések, az intézményrendszeri sajátosságok bemutatása - kiemelten a külön fejezetként bemutatott esettanulmányra -, az évtizedes hazai felhasználási gyakorlat tematizált esetleírásai, valamint a kontrafaktuális összehasonlító elemzés empirikus kutatási munkája egy komplex kérdésre adott komplex válasz szándékával készült. A disszertáció valódi és hosszú-távú haszna mindazon javaslatok, melyet hazánk a későbbi fejlesztés-politika, intézmény-kialakítás, szabályozás, mérés és monitorozás területén alkalmazni tud a szakirodalmi hiánypótláson, bővítésen és tovább kutatási területek nevesítésén túlmenően. A cél hazánkban is mind jobban alkalmazni a mottóként hivatkozott Brit Audit Hatóság jelmondatát: 
„Küldetésünk: segíteni a nemzetet bölcsen költeni (NAO [2009]).” 
HIVATKOZÁSOK JEGYZÉKE

XI. Pius pápa [1931]: Quadragesimo anno, enciklika, Vatikán, Róma. http://lexikon.katolikus.hu/Q/Quadragesimo\%20anno.html Lekérdezve: 2015. június 29.

Ahnborg et al [2012]: Friends of Better Spending (AT,DE, FR, FI; IT;NL,SE); http://www.europolitics.info/pdf/gratuit_en/313262-en.pdf ; Lekérdezve: 2013. június 5.

Állami Számvevőszék [2013]: „Jelentés a 2007-től uniós finanszírozással megvalósuló, kormányzati döntésen alapuló beruházási projektek pályáztatási, tervezési és előkészítési tapasztalatainak értékelése ellenőrzéséröl”. $\quad$ http://www.asz.hu/jelentes/1281/jelentes-a-2007-tol-uniosfinanszirozassal-megvalosulo-kormanyzati-dontesen-alapulo-beruhazasiprojektek-palyaztatasi-tervezesi-es-elokeszitesi-tapasztalatainak-ertekeleseellenorzeserol/1281j000.pdf; Lekérdezve: 2014. szeptember 21.

Babbie [2003]: A társadalomtudományi kutatás gyakorlata, 2003. Hatodik kiadás, Balassi Kiadó, Budapest

Balás [2013]: „Az EU-s támogatások területi kohézióra gyakorolt hatásainak értékelése." Hétfa Kutatóintézet; http://hetfa.hu/2013/08/az-eu-stamogatasok-teruleti-koheziora-gyakorolt-hatasainak-ertekelese/ Lekérdezve:2015. február 14.

Barca [2009]: AN AGENDA FOR A REFORMED COHESION POLICY. A place-based approach to meeting European Union challenges and expectations. Independent Report prepared at the request of Danuta Hübner, Commissioner for RegionalPolicy. European Comission. http://ec.europa.eu/regional_policy/archive/policy/future/barca_en.htm; Lekérdezve:2012.09.16.

Berky [2013]: „Intézményi kapacitásfejlesztés és a közigazgatás modernizációja” in: Nagy-Heil (szerk.) A kohéziós politika elmélete és gyakorlata. Budapest; Akadémiai Kiadó 
BMWE - Bundesministerium für Wirtschaft und Energie [2013 a]: Evaluierung der Gemeinschaftsaufgabe "Verbesserung der regionalen Wirtschaftsstruktur" (GRW) durch einzelbetriebliche Erfolgskontrolle 2013, Németország, http://bmwi.de/BMWi/Redaktion/PDF/Publikationen/evaluierunggemeinschaftsaufgabe, property $=$ pdf, bereich $=$ bmwi2012, sprache $=$ de,, $\mathrm{rwb}=$ true .pdf Lekérdezve: 2015. június 8.

BMWE - Bundesministerium für Wirtschaft und Energie [2013b]: Bedeutung und Wirksamkeit der Förderung größerer Unternehmen durch den gewerblichen Investitionszuschuss im Rahmen der Gemeinschaftsaufgabe "Verbesserung der regionalen Wirtschaftsstruktur" (GRW); Németország, http://www.bmwi.de/BMWi/Redaktion/PDF/G/grwfolgestudie, property=pdf, bereich=bmwi2012, sprache $=$ de,, $\mathrm{rwb}=$ true.pdf Lekérdezve: 2015. július 15.

Bradley [2006]: „Evaluating the Impact of European Union Cohesion Policy in Lessdeveloped Countries and Regions.” Regional Studies, Vol. 40. No. 2. p.189199. DOI:10.1080/00343404.2013.859666

BruxInfo [2011]: Erősebb Európai Szociális Alapot akar Andor László. BruxInfo, 2011.március 21. Brüsszel http://www.bruxinfo.hu/cikk/20110321-erosebbeuropai-szocialis-alapot-akar-andor-laszlo.html; Lekérdezve: 2013. 08.06.

BruxInfo [2012]: „Tollat ragadtak a kohézió barátai.” BruxInfo, 2012. február 16. Brüsszel. http://www.bruxinfo.hu/cikk/20120216-tollat-ragadtak-a-koheziobaratai.html; Lekérdezve: 2013. július 3.

BruxInfo [2013]: „Nem lesz 95\%-os uniós társfinanszírozás a magyar programoknál.” BruxInfo, 2013. november 24. Brüsszel; http://www.bruxinfo.hu/cikk/20131124-nem-lesz-95-os-uniostarsfinanszirozas-a-magyar-programoknal.html; Lekérdezve: 2014. január 4.

Burnside - Dollar [2000]: „Aid, Policies and Growth.” American Economic Review Vol.90 (No.4 Sept.): 847-868. ; DOI: 10.1257/aer.90.4.806 http://www.hec.unil.ch/ocadot/SECODEVdocs/Articles/Burnside-Dollar.pdf ; Lekérdezve: 2010.11.12. 
Campbell - Stanley [1963]: Experimental and Quasi-Experimental Designs for Research, Chicago, Rand McNally; p.5-6

Campbell - Cook [1979]: Quasi-Experimantation: Design and Analysis Issues for Field Settings, Chicago, Rnad McNally 1979. p.51-55

CAPAM [2010]: Overview of Case Study Models and Methodology; Commonwealth Association for Public Administration and Management http://www.capam.org/_documents/reportoncasestudymethodologies.pdf; Lekérdezve:2014. május 9.

Charron - Lapuente - Dijkstra [2012]: Regional Governance Matters:A Study on Regional Variation in Quality of Government within the EU, Working Paper - A series of short papers on regional research and indicators produced by the Directorate-General for Regional Policy. European Comission. 01/2012. http://ec.europa.eu/regional_policy/sources/docgener/work/2012_02_governa nce.pdf Lekérdezve: 2013.05.06.

CMRP [2012]: Common Position of 13 Cohesion Countries; The Conference of Peripheral Maritime Regions of Europe http://www.crpm.org/pub/agenda/1905_common_position_13_cohesion_cou ntries.pdf ; Lekérdezve: 2013. június 06.

Csite - Szepesi [2008]: Versengés a fejlesztési forrásokért - az I. NFT kistérségi hatásainak vizsgálata $A z I$. NFT eredményei és hatásai 10 kistérségben HBFHungaricum, Kecskemét; http://www.tokaj.hu/dl/media/group_47ce7dc01a102/group_47ce7dfa98eb2/it em_2225.pdf; Lekérdezve: 2014. október 6.

Czuriga [2009]: Az Európai Unió regionális politikája és eredményei Portugáliában - Konvergencia és divergencia a gyakorlatban. Doktori értekezés, BCE Nemzetközi Kapcsolatok Doktori Iskola, 2009. http://phd.lib.unicorvinus.hu/395/01/czuriga_eszter.pdf

Döbrönte - Vida [2014]: „A regionális politika és intézményrendszer szerepe Magyarországon.” Tér és Társadalom, Észak-Amerika, 18, aug. 2011. 
http://tet.rkk.hu/index.php/TeT/article/view/968/1933. Lekérdezve:

2014.március 24.

EC [2013]: Evaluation Guidance - Evalsed Guide and Sourcebook 2013;

http://ec.europa.eu/regional_policy/en/newsroom/news/2013/11/evaluationguidance-evalsed-guide-and-sourcebook-updates Lekérdezve: 2015. 06.17.

Ederveen - Groot -Nahuis [2006]: „Fertile Soil for Structural Funds?” A Panel Data Analysis of the Conditional Effectiveness of European Cohesion Policy. Kyklos, Greece Vol. 59.(No. 1.): 17-42.

EP és ET [2013a]: AZ EURÓPAI PARLAMENT ÉS A TANÁCS 1299/2013/EU RENDELETE (2013. december 17.) az Európai Regionális Fejlesztési Alap által az európai területi együttmüködési célkitüzésnek nyújtott támogatásra vonatkozó egyedi rendelkezésekről. Az Európai Unió Hivatalos Lapja , L 347/259, 2013.12.20. $\quad$ http://eur-lex.europa.eu/legalcontent/HU/TXT/PDF/?uri=CELEX:32013R1299\&from=HU

EP és ET [2013b]: EURÓPAI PARLAMENT ÉS A TANÁCS 1300/2013/EU RENDELETE (2013. december 17.) a Kohéziós Alapról, és az 1084/2006/EK tanácsi rendelet hatályon kívül helyezéséröl. Az Európai Unió Hivatalos Lapja, L 347/281, 2013.12.20. $\quad$ http://eur-lex.europa.eu/legalcontent/HU/TXT/PDF/?uri=CELEX:32013R1300\&from=HU

EP és ET [2013c]: AZ EURÓPAI PARLAMENT ÉS A TANÁCS 1301/2013/EU RENDELETE (2013. december 17.) az Európai Regionális Fejlesztési Alapról és a „Beruházás a növekedésbe és munkahelyteremtésbe"célkitüzésről szóló egyedi rendelkezésekről, valamint az 1080/2006/EK rendelet hatályon kívül helyezéséröl. Az Európai Unió Hivatalos Lapja , L 347/289, 2013.12.20. http://eur-lex.europa.eu/legalcontent/HU/TXT/PDF/?uri=CELEX:32013R1301\&from=HU

EP és ET [2013d]: AZ EURÓPAI PARLAMENT ÉS A TANÁCS 1302/2013/EU RENDELETE (2013. december 17.) az európai területi együttmüködési csoportosulásról szóló 1082/2006/EK rendeletnek a csoportosulások létrehozásának és müködésének egyértelművé tétele, egyszerüsítése és javítása tekintetében történő módosításáról. Az Európai Unió Hivatalos

Lapja, L 347/303, 2013.12.20. http://eur-lex.europa.eu/legalcontent/HU/TXT/PDF/?uri=CELEX:32013R1302\&from=HU 
EP és ET [2013e] AZ EURÓPAI PARLAMENT ÉS A TANÁCS 1303/2013/EU RENDELETE (2013. december 17.) az Európai Regionális Fejlesztési Alapra, az Európai Szociális Alapra, a Kohéziós Alapra, az Európai Mezőgazdasági Vidékfejlesztési Alapra és az Európai Tengerügyi és Halászati Alapra vonatkozó közös rendelkezések megállapításáról, az Európai Regionális Fejlesztési Alapra, az Európai Szociális Alapra és a Kohéziós Alapra és az Európai Tengerügyi és Halászati Alapra vonatkozó általános rendelkezések megállapításáról és az 1083/2006/EK tanácsi rendelet hatályon kívül helyezéséről. Az Európai Unió Hivatalos Lapja L 347/320 2013.12.20. http://eurlex.europa.eu/legalcontent/HU/TXT/PDF/?uri=CELEX:32013R1303\&from=HU

EP és ET [2013f] AZ EURÓPAI PARLAMENT ÉS A TANÁCS 1304/2013/EU RENDELETE (2013. december 17-én) az Európai Szociális Alapról és az 1081/2006/EK tanácsi rendelet hatályon kívül helyezéséről. Az Európai Unió Hivatalos Lapja, L 347/470, 2013.12.20. http://eur-lex.europa.eu/legalcontent/HU/TXT/PDF/?uri=CELEX:32013R1304\&from=HU

EP és ET[2013g]: AZ EURÓPAI PARLAMENT ÉS A TANÁCS 1305/2013/EU RENDELETE (2013. december 17.) az Európai Mezőgazdasági Vidékfejlesztési Alapból (EMVA) nyújtandó vidékfejlesztési támogatásról és az 1698/2005/EK tanácsi rendelet hatályon kívül helyezéséről. Az Európai Unió Hivatalos Lapja ,L 347/487,2013.12.20. http://eur-lex.europa.eu/legalcontent/HU/TXT/PDF/?uri=CELEX:32013R1305\&from=HU

EPRC - European Policies Research Centre [2014]: „Evaluating the Effectiveness of Regional Policy” EoRPA Paper 14/6 September 2014; http://www.eprc.strath.ac.uk/eorpa/Documents/EoRPA_14_Conf/EoRPA_Pa per_14-6_Final.pdf Lekérdezve: 2015. 01.16.

Ernst \& Young [2015]: „EX-ANTE Értékelő Jelentés az Emberi Erőforrás Fejlesztési Operatív Program 2015. január 6-án elkészült, az Európai Bizottságnak elfogadásra benyújtott változatáról”. Budapest, 2015. 03.25. http://palyazat.gov.hu/2014_2020_as_operativ_programok_tarsadalmi_egyezt etese Lekérdezve: 2015. május 5.

ET [2013]: A TANÁCS 1311/2013/EU, EURATOM RENDELETE (2013. december 2.) a 2014-2020-as időszakra vonatkozó többéves pénzügyi keretről. Az 
Európai Unió Hivatalos Lapja, L 347/884, 2013.12.20. http://eur$\underline{\text { lex.europa.eu/LexUriServ/LexUriServ.do?uri=OJ:L:2013:347:0884:0891:HU }}$ :PDF

EVALSED [2013]: GUIDE to the evaluation of Socioeconomic Development; The resource for the evaluation of Socio-Economic Development; 2013 http://ec.europa.eu/regional_policy/sources/docgener/evaluation/guide/guide evalsed.pdf Lekérdezve: 2015. június 4.

Farole - Rodrígues-Pose -Storper [2011]: „Cohesion Policy in the European Union: Growth, Geography, Intstitutions". Journal of Common Market Studies, 2011.Volume 49. Number 5. p1103-1104; DOI: 10.1111/j.14685965.2010.02161.x).

Győriné [2014]: „Bravúrra lesz szükség a támogatások lehívásához”. BruxInfo, Brüsszel. 2014.április 23. http://bruxinfo.eu/cikk/20140423-szorit-a-jovo-evvegi-hatarido-az-unios-penzek-maradektalan-elkoltesehez.html Lekérdezve: 2015. szeptember 21.

Győriné [2015]: „A 2014-2020-as kohéziós források felhasználásának hazai vállalásai az uniós kötelezettségek szorításában” Köz-Gazdaság 2015/4.

Hahn [2013]: Refocusing EU Cohesion Policy for Maximum Impact on Growth and Jobs: The Reform in 10 points. European Commission. http://europa.eu/rapid/press-release_MEMO-13-878_en.htm ; Lekérdezve: 2014. február 13.

Kengyel [2008]: Kohézió és finanszirozás. Az Európai Unió regionális politikája és költségvetése. Akadémiai Kiadó, Budapest.

Kengyel [2012]: „Az Európai Unió kohéziós politikájának integrációs jelentősége és szabályozásának jövője.” Közgazdasági Szemle, LI X. évf., 2012. március (311-332. o.)

Kengyel [2015a]: „Szubszidiaritás az EU és tagállamai regionális politikájában.” Prosperitas, II. évf. (2015/1) (20-36. o.)

Kengyel [2015b]: „Kohéziós politika és felzárkózás az Európai Unióban”; habilitációs értekezés, Budapest, Corvinus Egyetem 
Kozak [2006]: „Managing European regional policy in Poland in the initial period after the accession"; Regional and Local Studies - special issue 2007; http://www.euroreg.uw.edu.pl/dane/web_euroreg_publications_files/1220/20 07_5_kozak.pdf Lekérdezve: 2014.március 31.

Krajowa Jednostka Ewaluacji [2009]: Lengyel Értékelési Egység honlapja; https://www.ewaluacja.gov.pl/english/strony/evaluation.aspx; Lekérdezve: 2014. május 13.

Kullmann [2013]: „Stratégia, programok és projektfejlesztés” in: Nagy-Heil (szerk.) A kohéziós politika elmélete és gyakorlata. Budapest; Akadémiai Kiadó

Magyarország Kormánya [2012] - Magyary Program (2012.) A területfejlesztésről és területrendezésről szóló 1996. évi XXI. törvény 2012. január 1-én hatályba lépett módosításának utólagos hatásvizsgálata; Projekt kódszám: ÁROP1.1.19 Fejlesztéspolitika/Területfejlesztési projekt hatásvizsgálat; http://magyaryprogram.kormany.hu/download/8/bf/70000/Hat\%C3\%A1svizs g\%C3\%A1lat_Ter\%C3\%BClelfejleszt\%C3\%A9s_02.pdf; Lekérdezve: 2014. május 16.

Mezei - Schmidt [2013]: „A lengyel regionális politika és intézményei.” Tér és Társadalom, Észak-Amerika, 27, aug. 2013. http://tet.rkk.hu/index.php/TeT/article/view/2477/4685. Lekérdezve: 2014. március 23.

Mohl-Hagen [2010]: „Do EU structural funds promote regional growth? New evidence from various panel data approaches." Regional Science and Urban Economics ; Vol 40, Issue 5, September 2010, Pages 353-365 ;

DOI:10.1016/j.regsciurbeco.2010.03.005

Molle [2008]: „Enhancing the Efficiency of the EU Funds through Better Coordination." Society and Economy, Vol. 30. No. 2. p.275-292. DOI: $10.1080 / 03085140120042262$

Nagy [2008]: „Az európai uniós támogatások hatékonysága és hatásossága közötti különbség a ROP 1.2 intézkedésnél.” Európai Tükör, 2008. június p.102-111.

Nagy [2010]: „A kohéziós politika hatékonysága.” Köz-Gazdaság 2010/4 117-135. 
NAO - National Audit Office [2009]: Nemzeti Audit Hivatal hivatalos weboldala http://www.nao.org.uk/wp-content/uploads/2014/12/NAO-Strategy-2015-162017-18-Infographic.pdf; Letöltés: 2015. május 28.

NAO - National Audit Office [2012]: „Regionális Növekedési Alap” http://www.nao.org.uk/wp-content/uploads/2012/05/121317.pdf; Lekérdezve: 2015. május 28.

NAO - National Audit Office [2015]: Nagy-Britannia, http://www.nao.org.uk/wpcontent/uploads/2014/12/NAO-Strategy-2015-16-2017-18-Infographic.pdf Lekérdezve: 2015. május 28.

Nyikos [2011]: How to deliver an integrated territorial approach to increase the effectiveness of public interventions, Panel Debate at High-level Conference Integrated Approach to Development - a Key to Smart, Sustainable and Inclusive Europe, 24. November 2011. Poznan

Nyikos [2013]: „A közfinanszírozásból megvalósított fejlesztések hatásai, különös tekintettel az EU kohéziós politikára”. Pénzügyi Szemle 2013/2 p.165185 p.175-178 http://www.asz.hu/penzugyi-szemle-cikkek/2013/akozfinanszirozasbol-megvalositott-fejlesztesek-hatasai-kulonos-tekintettel-azeu-kohezios-politikara/165-185-nyikosgyorgyi-2013-2.pdf

Pálné Kovács [2003]: A területfejlesztés irányitása. Pécsi Tudományegyetem Közgazdaságtudományi Kar, Regionális Politika és Gazdaságtan Doktori Iskola, Pécs

Perger [2010]: „Az EU kohéziós politika kormányzati irányításának magyar sajátosságai.", Tér és Társadalom 24. évf. 2010/1. p.119-136, http://tet.rkk.hu/index.php/TeT/article/view/1299/2594;

Lekérdezve: 2014.05.09.

Potluka-Brůha [2014]: „EU Cohesion Policy attribution to employment: a case of the Czech Republic"; http://www.ecpr.eu/Filestore/PaperProposal/e13a36964251-4f98-8800-d72e79c343ba.pdf Letöltés: 2015. június 10. 
Rekenkamer [2014]: „EU Trendrapport 2014”; Hollandia. http://www.rekenkamer.nl/Publicaties/Onderzoeksrapporten/Introducties/201 4/02/EU_trendrapport_2014, Lekérdezve: 2015. június 17.

Roethlisberger - Dickson [1939] „Management and the Worker”, Cambridge, MA, Harvard University Press

Szikszainé [2007] Magyar stilisztika, Osiris Kiadó, Budapest

Teszler [2005]: „, Az Európai Unió külső fejlesztési alapjaiban való hatékony magyar részvétel az integráció-érettség tükrében." Doktori $(\mathrm{PhD})$ értekezés, Budapesti Corvinus Egyetem, Nemzetközi Kapcsolatok Doktori Iskola. http://phd.lib.uni-corvinus.hu/142/ Lekérdezve: 2011. szeptember 15.

Valenza et al [2011]: POR CRO FESR REGIONE MARCHE 2007-2013SERVIZIO DI VALUTAZIONE DEGLI INTERVENTI ATTUATIA FAVORE DELLA RICERCA E DELL'INNOVAZIONE; http://ec.europa.eu/regional_policy/sources/docgener/evaluation/library/italy/ 1112 italy_marche_eval_it.pdf, Lekérdezve: 2015. június 10.

Varga, J.-in't Veld, J. [2010]: „The Potential Impact of EU Cohesion Policy Spending in the 2007-2013 Programming Period: A Model-Based Analysis”. European Economy. Economic Papers, 422. September 2010. Brussels. http://ec.europa.eu/economy_finance/publications/economic_paper/2010/pdf/ ecp422_en.pdf. DOI: 10.2765/43684 


\section{PUBLIKÁCIÓS JEGYZÉK}

\section{Tudományos könyv, könyvfejezet}

Győriné [2010]: Exchange Rates and Convertibility in New Member States.

Tanulmányok az európai integráció témaköréből (in.Palánkai szerk.) 3. kötet,

1. kiadás, Savaria Univetsity Press, Szombathely. ISBN:978-963-988239-3. pp. $219-225$.

\section{$\underline{\text { Referált szakmai folyóirat }}$}

Győriné [2014]: „A Kohéziós Alapok hatékonyabb felhasználása”. Külügyi Szemle XIII. évfolyam 2014/4;163-181; http://kki.gov.hu/kulugyi-szemle-2014-4

Győriné [2015]: „A 2014-2020-as kohéziós források felhasználásának hazai vállalásai az uniós kötelezettségek szorításában”. Köz-Gazdaság, X. évfolyam 2015/4. ; http://www.uni-corvinus.hu/index.php?id=58046

$\underline{\text { Idegen nyelvü publikációk }}$

Győriné [2016]: Evaluation Synthesis of Efficiency Measurements of Cohesion Funds at the Level of Member States. Köz-Gazdaság, XI. évfolyam 2016/5. ; http://www.uni-corvinus.hu/index.php?id=58021

\section{$\underline{\text { Egyéb }}$}

Győriné [2014] : „Az Európai Unió kohéziós forrásainak felhasználása - A szabályozás és hatékonyság összefüggései”. E-CONOM III. évfolyam 2014/2. pp.18-31;DOI:10.17836/EC.2014.2.03; 
Győriné [2014]: „A Kohéziós Alapok hatékonyabb felhasználása” Tavaszi Szél 2014. Ph.D konferencia, Doktoranduszok Országos Szövetsége; Konferenciakötet I. pp.152-158

Győriné [2014]: „, Lehívás és minőségi költés - A Kohéziós Alapok hatékony felhasználása"; Konferenciakötet; VIII. Ph.D. konferencia, Professzorok az Európai Magyarországért Egyesület; I. kötet, 2014. pp. 22-26

Győriné [2014]: „Bravúrra lesz szükség a támogatások lehívásához”. BruxInfo, Brüsszel. 2014.április 23. http://bruxinfo.eu/cikk/20140423-szorit-a-jovo-evvegi-hatarido-az-unios-penzek-maradektalan-elkoltesehez.html Lekérdezve: 2015. szeptember 21.

\section{Idegen nyelvü publikációk}

Győriné [2014]: Current Trends and Special Characteristics in the Spending of the European Union's Regional Development Funds. European Scientific Journal; VOL. 10.No:16; pp.392-399.

Győriné [2014]: How the Institutional System Charged with Regional Development Policy Actually Imapct the Use of Cohesion Funs: As reflected by a Comparative Analysis of Poland and Hungary. European Scientific Journal, VOL.10; No:19; pp. 20-31. 